\title{
У ИСТОКОВ СОВЕТСКОЙ АРХЕОЛОГИИ: ОРГАНИЗАЦИИ И УЧРЕЖДЕНИЯ АРХЕОЛОГИЧЕСКОГО ПРОФИЛЯ В НОВЫХ РЕАЛИЯХ
}

\author{
МАТЕРИАЛЫ МЕЖДУНАРОДНОЙ \\ НАУЧНОЙ КОНФЕРЕНЦИИ \\ 26-27 февраля
}




\author{
Ответственный редактор: \\ к.и.н. И.А. Сорокина
}

Рецензенты:

д.и.н. Ш.Н. Амиров

д.и.н. Ю.Б. Цетлин

У истоков советской археологии: организации и учреждения
У11 археологического профиля в новых реалиях. Материалы Международной научной конференции / Отв. ред. И.А. Сорокина. М.: Институт археологии РАН. 2019. - 64 с.

\title{
ISBN 978-5-94375-275-9
}

Настоящее издание представляет собой сборник материалов, подготовленных к Международной научной конференции «У истоков советской археологии: организации и учреждения археологического профиля в новых реалиях» (Москва, 26-27 февраля, 2019 г.), прошедшей в год 100-летнего юбилея академической археологии в России и продолжающей серию проведенных Институтом археологии РАН форумов по истории российской археологии. Статьи дают представление о деятельности столичных и провинциальных музеев, образовательных учреждений, научных и краеведческих обществ с 1918 г. по начало 1930-х гг. Рассматриваются вопросы организации и проведения полевых исследований, в том числе и в системе ГУЛАГ 1930-х гг., новые теоретические подходы, процесс формирования профильных архивов, административная организация археологической науки, личные судьбы ученых и краеведов.

Сборник представляет интерес для археологов, историков, краеведов и для всех, кто интересуется историей отечественной науки.

УДК 902/904

ББК 63.4

ISBN 978-5-94375-275-9

DOI: 10.25681/IARAS.2019.978-5-94375-275-9

(c) Федеральное государственное бюджетное учреждение науки Институт археологии Российской академии наук, 2019

(C) Авторы докладов (фамилии выделены в содержании), 2019 


\section{СОДЕРЖАНИЕ}

Введение . . . . . . . . . . . . . . . . . . . . . . . . . . . . . . . . . . . . .

Алкин С.В. Археология Забайкалья в период существования Дальневосточной Республики $(1920-1922)$. . . . . . . . . . . . . . . . . . . . . . .

Белова Н.А., Медведева М.В. Архив Академии истории материальной культуры в 1920-1930-е гг. Судьба документальных собраний ведущих археологических учреждений России . . . . . . . . . . . . . . . . . . .

Белозёрова И. В., Кузьминых С.В. Государственный исторический музей и становление советской археологии в 1920-е годы (по материалам Отдела письменных источников ГИМ) . . . . . . . . . . . . . . . . . . . . . .

Бессуднов А.Н. Археологическая деятельность тамбовских любителей старины в новых реалиях: от Ученой архивной комиссии к краеведческим обществам 1920 -х годов . . . . . . . . . . . . . . . . . . . . . .

Бойко А.Л., Толочко И.В. Донские археологи в условиях «советизации» и времени «политического бандитизма» . . . . . . . . . . . . .

Вдовин А. С., Макаров Н.П. У истоков советской археологии: Красноярский музей в 1920-е годы (к 130-летию Красноярского краеведческого музея).

Евгеньев А.А. Оренбургское отделение Московского археологического института: опыт организации профильного образования в провинции в начале 1920 -х годов . . . . . . . . . . . . . . . . . . . . . . . . . . . . . . . . . .

Жукова Е.Н. Государственные учреждения Тверской губернии: возможности археологических исследований $\ldots \ldots \ldots \ldots \ldots \ldots \ldots \ldots \ldots \ldots \ldots \ldots \ldots \ldots \ldots \ldots \ldots$

Захарова Е.Ю., Бояркин М.В. «Работа велась так интенсивно и была так тяжела...»: о музейной археологии в Воронежской губернии 1920-х годов . .

Канторович А.Р. К предыстории кафедры археологии исторического факультета МГУ ................................... 2

Китова Л.Ю. У истоков советской археологии в Сибири ........... 26

Левченко В.В. К истории сохранения Ольвии в реалиях 1914-1930 годов . 28

Мельникова О.М. Археология на территории Удмуртии в 1920 - начале 1930-х годов: от научных обществ к научным учреждениям . . . . . . . . . 29

Непомнящий А.А. Ученое совещание при КрымОХРИСе: становление научного памятниковедения в регионе $(1920-1921) \ldots \ldots \ldots \ldots \ldots \ldots \ldots$

Палиенко С.В. Вопросы организации советской археологической науки 1920-х - начала 1930-х годов в творчестве советских археологов-теоретиков последней трети ХХ . . . . . . . . . . . . . . . . . . . . . . .

Панкратова Е.Г. Археологические экспедиции 1930-х годов на территории ГУЛАГа (по материалам Санкт-Петербургского филиала Архива РАН) . 
Платонова Н.И. Археология в СССР 1920-х годов: попытка социобиоло-

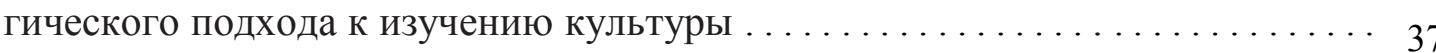

Руденко К.А. Реформы Б.Ф. Адлера в Казанском городском музее в 1917-1922 годах: археологические коллекции - инновация или уничтожение? .

Савенко С.Н. Участие РАИМК и ГАИМК в развитии археологических исследований на Кавминводах и в Терской области в 1920-е - середине1930-х

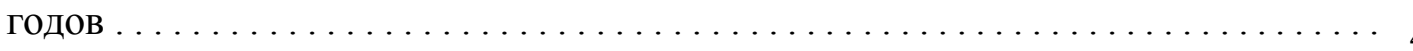

Сорокина И.А. О полевой археологии первых 15-и лет советской власти

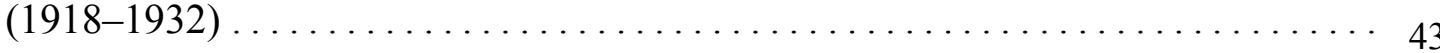

Сташенков Д.А. Археологические работы в Самарской губернии на переломе эпох: 1918-1930 годы . . . . . . . . . . . . . . . . . . . . . 4

Тихонов И.Л. Становление системы археологического образования в

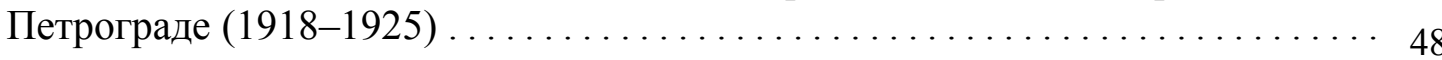

Ткачёв А.Н. ЛИЭТО: первое археологическое общество Кубани . . . . . 50

Тункина И.В. В.В. Латышев: нереализованные проекты 1917-1921 годов · 52

Усачук А.Н. Попытка организации археологических исследований в Сталинском музее краеведения (Донбасс, конец 20-х - начало 30-х годов XX

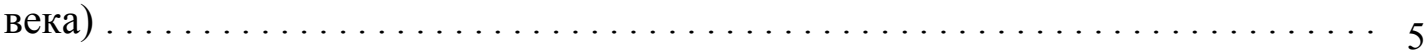

Щавелёв С.П. Обреченный арьергард: «Дело краеведов ЦЧО» 1930-1931 годов как трагический финал организованной археологии в российской про-

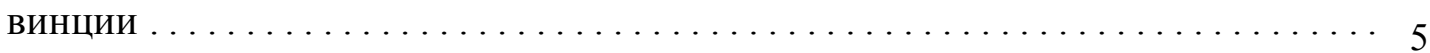

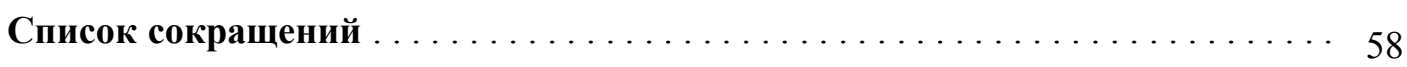

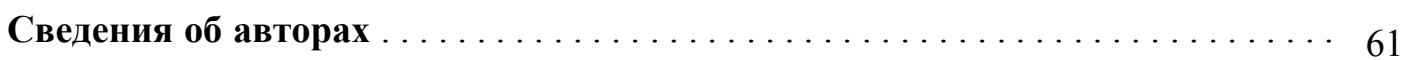




\section{ВВЕДЕНИЕ}

Сложно представить себе более значимое событие в истории нашей страны за последние несколько сотен лет, чем череда катаклизмов, произошедших в 1917 г. Этот год абсолютно правомерно становится самым главным рубежом российской истории $\mathrm{XX}$ века, значимым во всех смыслах - политическом, социальном, культурном и, прежде всего, историческом. Неудивительно, что вся отечественная историография, и археологическая в том числе, проводит границу между этапами развития научной мысли по 1917 году.

Трагические и судьбоносные события этого времени уже становились предметом особого внимания специалистов по истории археологии. Не далее как два года назад в стенах Института археологии РАН прошла конференция, посвященная обсуждению многочисленных свидетельств того, как встретила российская археологическая общественность революционные дни 1917 года. Прозвучавшие доклады в краткой форме отображены в вышедших материалах конференции (1917 год, 2017).

Однако далеко не все вопросы, связанные с кардинальными изменениями, произошедшими в отечественной археологии после 1917 года, получили одинаковое освещение в ходе означенного мероприятия. Прежде всего, это касается значительных перемен, произошедших в области организации науки - в исчезновении старых и появлении новых археологических учреждений. Далеко не все из них исчезали и возникали сразу после Октябрьского переворота - процесс сложения археологических институций, привычных нам сегодня, растянулся почти на полтора десятилетия и завершился в той или иной степени лишь к концу 1920-х - началу 1930-х гг.

Освещению разных сторон этого сложного, порой запутанного процесса посвящена настоящая конференция «У истоков советской археологии: организации и учреждения археологического профиля в новых реалиях». Следует отметить, что это далеко не первая попытка осмысления организационных процессов становления советской археологии - подобные вопросы, например, представляли интерес для археологов-теоретиков последней трети XX в., чему посвящен особый доклад С.В. Палиенко.

Большинство представленных на конференции докладов охватывает период становления и формирования археологических организаций в новых советских реалиях 1917 г. - начало 1930-х гг. Это и формирование нового научного подхода к изучению культуры (Н.И. Платонова), и работа археологов в возникавших новых государственных образованиях наподобие Дальневосточной республики (С.В. Алкин), и сложные взаимоотношения представителей археологической науки и советской власти на Дону (А.Л. Бойко, И.В. Толочко) и в Оренбуржье (А.А. Евгеньев), в Сибири (Л.Ю. Китова) и Удмуртии (О.М. Мельникова), в Крыму (А.А. Непомнящий) и на Кавказе (С.Н. Савенко).

Особое внимание уделено особенностям организации археологической деятельности в этих непростых условиях становления новой государственности - формированию архивов (Н.А. Белова и М.В. Медведева), обустройству музейных экспозиций (И.В. Белозёрова и С.В. Кузьминых, А.С. Вдовин и Н.П. Макаров, Е.Ю. Захарова и М.В. Бояркин, К.А. Руденко), проведению полевых изысканий (И.А. Сорокина, Д.А. Сташенков), преподаванию археологии в высших учебных заведениях (Е.Н. Жукова, А.Р. Канторович, И.Л. Тихонов). Важный вклад вносился археологами в первые годы советской власти, в условиях полной дезорганизации и фактического отсутствия государственных структур, в сохранение археологических памятников (В.В. Левченко). Одним из главнейших трендов в новой советской реальности становится широкое краеведческое дви- 
жение (А.Н. Бессуднов, А.Н. Ткачёв, А.Н. Усачук), впоследствии подвергшееся жесточайшему разгрому (С.П. Щавелёв).

Не обойдены молчанием трагические события, затронувшие многих российских ученых в годы большевизма. Экономическая разруха и голод, политические репрессии и ужасы Гражданской войны привели к гибели многих лучших людей России того времени. За скупыми данными архивов проступают подлинные человеческие трагедии голодная смерть В.В. Латышева в Петрограде в 1921 г. (И.В. Тункина), использование археологами в экспедициях подневольного труда узников ГУЛАГа (Е.Г. Панкратова).

Не приходится сомневаться в том, что тема настоящей конференции вызовет живой интерес у археологов нынешнего столетия. Ведь истоки современной российской археологии в большой степени сформировались именно тогда, в начальные советские годы, неся с собой как некоторые положительные стороны, например, возросший демократизм научной жизни и вовлечение широких слоев населения в изучение прошлого на гораздо более обширной территории, чем этот было до 1917 года, так и несомненный груз проблем, который советская археология несла с собой до рубежа 1980-х - 1990-х гг. - идеологический пресс государства, оторванность от европейской и мировой научной мысли, значительный схематизм в теоретических построениях и пр. Преодоление груза старых проблем и поступательное развитие археологической науки в наши дни невозможно без осмысления ее истоков, особенно сейчас, когда в текущем году отмечается столетний юбилей академической археологии в России. Надеемся, что настоящая конференция внесет свой позитивный вклад в этот процесс осознания российской археологией своего исторического места.

\section{ЛИТЕРАТУРА}

1917 год, 2017. 1917 год: российская археология на переломе эпох. Материалы Международной научной конференции / Отв. ред. И.А. Сорокина. М.: Институт археологии РАН. 92 с. 


\section{АРХЕОЛОГИЯ ЗАБАЙКАЛЬЯ В ПЕРИОД СУЩЕСТВОВАНИЯ ДАЛЬНЕВОСТОЧНОЙ РЕСПУБЛИКИ (1920-1922)}

В ходе Гражданской войны весной 1920 г. в качестве буферного государства между Советской Россией и Японией была создана Дальневосточная республика (ДВР). Она включила в себя территорию к востоку от озера Байкал, в том числе Забайкальскую область. С октября 1920 г. столицей нового государственного образования стал город Чита. Правительство РСФСР ставило перед руководством ДВР, прежде всего, военнополитические задачи, которые были успешно выполнены к концу 1922 г., что повлекло за собой ликвидацию ДВР и вхождение территорий Восточной Сибири и Дальнего Востока в состав Советского государства. Период ДВР стал временем определенной стабилизации хозяйственной и культурной жизни в регионе после ликвидации белой государственности. Правительство ДВР уделяло большое внимание восстановлению системы образования, а также поддержке Забайкальского отделения Русского географического общества (ЗОРГО) и его краеведческого музея. Законы ДВР способствовали развитию массового краеведческого движения. Таким образом, в новых условиях были продолжены музейная и просветительская деятельность, важной составной частью которых было изучение и популяризация археологических древностей края.

В 1921 г. правительство ДВР взяло на себя финансирование ЗОРГО и музея, передав его в ведение Министерства народного просвещения. Был создан Государственный институт народного образования (ГИНО), где преподавали местные краеведы и музейные работники, а также оказавшиеся в Чите в связи с событиями Гражданской войны педагоги и научные работники с Урала и Дальнего Востока. Учащиеся не только слушали лекции по истории края, но также принимали участие в экскурсиях в окрестностях города, помогали в каталогизации фондов краеведческого музея. В Читинском музее в рамках программы инструкторских курсов для учителей проводились занятия по археологии, на которых лекции читал А.К. Кузнецов. Он руководил музеем, сам глубоко интересовался археологией и пользовался большим авторитетом в Сибири и на Дальнем Востоке. В архиве Забайкальского краевого краеведческого музея (ЗККМ) и Государственном архиве Забайкальского края (ГАЗК) сохранилась его переписка периода 1920 1922 гг. с С.М. Широкогоровым (1887-1939), где обсуждались вопросы археологической работы на Дальнем Востоке и сопредельной территории Китая.

Выходец из кружка народоведения при Иркутском университете Е.И. Титов (18961938) работал преподавателем ГИНО и учителем в школе. В ходе экскурсий открыл ряд местонахождений в окрестностях Читы, включая первое русское поселение на месте города, верхнепалеолитические памятники на Титовской сопке. Учащиеся были ознакомлены с приемами поиска археологических памятников, проведения глазомерной съемки местности, методикой шурфовки и регистрации собранного материала. Позднее Е.И. Титов подготовил методические указания по проведению археологических экскурсий в районе Читы (Алкин, 2009).

Значительный вклад в археологию Забайкалья внес уральский археолог В.Я. Толмачёв (1876-1942), который некоторое время находился в Чите по пути в эмиграцию. В ГИНО он вел курс первобытной истории (ГАЗК. Ф. Р-32. Оп. 2. № 1. Л. 40), обследовал берега озера Кенон в черте города, передав затем коллекцию предметов раннего железного века в фонды музея. Толмачёв выступил с докладом «Об археологических находках в окрестностях г. Читы» (ГАЗК. Ф. Р-1545. Оп. 1. № 1. Л. 22-22 об.). После отъезда в Харбин В.Я. Толмачёв поддерживал контакты с коллегами в Чите, в частности отправляя издания ОИМК. Позднее им была опубликована статья о погребениях в районе города Сретенска (1929), которая до начала 1960-ых гг. оставалась единственной специальной работой по археологии этой части бассейна Верхнего Амура. 
Материалы по археологии и методической работе публиковались в изданиях Министерства просвещения. Министр народного просвещения ДВР, профессор ГИНО А.А. Половинкин (1887-1955) в 1922 г. подготовил для учащихся брошюру «Что было на Чёртовом бугре», которая признана первым учебным пособием по археологии Забайкалья, где были представлены и элементы методики (Константинов, 2008. С. 198-200).

Продолжалась археолого-краеведческая работа на юго-западе ДВР в городе Кяхта одном из старейших музейных центров на Востоке страны. С 1922 г. его директором стал П.С. Михно (1867-1938), который с начала 1890-х гг. имел опыт самостоятельного археологического поиска в приграничных районах Забайкалья, Монголии и Маньчжурии. Новый руководитель уделял большое внимание пополнению археологических фондов музея (Константинов, 2008. С. 64-65).

После присоединения территории ДВР к Советскому государству и с переводом во Владивосток в 1923 г. Забайкальского университета (был создан на базе ГИНО в 1922 г.) многие специалисты покинули Забайкалье, а некоторые и Россию. Тем не менее, интерес к археологии лидера краеведов региона А.К. Кузнецова, работа со школьниками Е.И. Титова, активность музейных работников по-прежнему способствовали популяризации знаний о древней истории края и пополнению археологических коллекций Читинского краеведческого музея. Если в 1920-1922 гг. не было опубликовано ни одной специальной работы по археологии Забайкальского края, то начиная с 1924 г. осуществляется публикация результатов работ этого периода.

В 1923 г. состоялась первая в истории новой российской государственности археологическая экспедиция в районы Забайкалья. Она была организована РАИМК при участии Русского музея (Петроград). Руководителем был назначен С.И. Руденко. Он обследовал местонахождения каменного века в долине реки Онон (Археологические..., 1962. C. 24).

И все же в период до 1925 г. наблюдался серьезный кризис в музейной и краеведческой деятельности, что отразилось на интенсивности изучения археологии региона. Этот кризис был преодолен во второй половине 1920-х - 1930-х гг., когда в России завершился этап выделения археологии как отдельной научной дисциплины, что происходило на фоне становления новых отношений между наукой и властью в нашей стране.

Таким образом, период Дальневосточной республики послужил переходным моментом от дореволюционного этапа археологического изучения территории Забайкалья, когда была предпринята в целом успешная попытка сохранить музейные кадры, поддержать краеведческое движение, использовать знания и опыт оказавшихся в Чите археологов-профессионалов. В результате была сохранена основа для организации археолого-краеведческих исследований Забайкалья в составе РСФСР.

\section{ЛИТЕРАТУРА}

Алкин С.В. Исследователь коренного населения Восточной Сибири Елпидифор Иннокентьевич Титов // Вузовская научная археология и этнология Северной Азии. Иркутская школа 1918-1937 гг.: Материалы всероссийского семинара, посвященного 125-летию Бернгарда Эдуардовича Петри. Иркутск, 3-6 мая 2009 г. Иркутск: Амтера, 2009. C. 10-21.

Археологические..., 1962. Археологические экспедиции Государственной академии истории материальной культуры и Института археологии Академии наук СССР 1919-1956 гг.: Указатель. М.: Изд-во АН СССР, 1962. 264 с.

Константинов М.В. Провинциальная археология. Чита: Изд-во Заб. гос. гум.- пед. Ун-та, 2008. $296 \mathrm{c.}$ 


\section{АРХИВ АКАДЕМИИ ИСТОРИИ МАТЕРИАЛЬНОЙ КУЛЬТУРЫ В 1920-1930-е ГОДЫ. СУДЬБА ДОКУМЕНТАЛЬНЫХ АРХИВОВ ВЕДУЩИХ АРХЕОЛОГИЧЕСКИХ УЧРЕЖДЕНИЙ РОССИИ}

В течение 1920-1930 гг. в России произошла полная реформация структуры отечественной археологической науки (Платонова, 2010. С. 215-253). Ведущие археологические и исторические общества дореволюционного периода, комитеты, комиссии и институты Санкт-Петербурга и Москвы преобразовывались, а чаще ликвидировались. На рубеже 1920-1930-х гг. реорганизованы были и учреждения, созданные после революции и занимавшиеся археологией и охраной памятников в 1920-е гг. Накопленные за годы их существования богатейшие коллекции музейных предметов и собрания документов и книг рассеивались по разным хранилищам. В настоящее время проследить пути их распределения и восстановить изначальный состав собраний бывает весьма сложно из-за несовершенства учетной документации того времени и отсутствия единства между научными, музейными и архивными учреждениями по вопросу, где и каким образом должны были храниться материалы научных организаций. О судьбе многих из них могут рассказать документы Научного архива ИИМК РАН.

Больше всего повезло архиву Императорской археологической комиссии (ИАК), которая не была уничтожена и продолжила свою деятельность в преобразованном виде. Затем все имущество комиссии, в том числе библиотека и архив, перешли в распоряжение ее наследницы - Академии истории материальной культуры (РАИМК-ГАИМК), которой удалось не только сохранить документальные комплексы ИАК в целостности, но и значительно пополнить архив в 1920-1930 гг. за счет материалов закрытых в тот период учреждений (Пескарева, Владимирова, 1980. С. 88; Девель, С. 289-313).

С 1919 г. начинает формироваться и собственный документальный архив Академии истории материальной культуры. Рукописные и фотографические документы отражали работу учреждения в целом, а также научно-исследовательскую, экспедиционную, педагогическую и просветительскую деятельность сотрудников Академии.

Академия истории материальной культуры с 1919 по 1937 г. располагалась в Мраморном дворце и поэтому оказалась в эпицентре перераспределения всего дворцового имущества, владельцами которого до революции были великие князья из ветви Константиновичей. Документальный архив был полностью передан в Центрархив, а фотоколлекция перешла в фотоархив Академии, где и хранится до сих пор.

После ликвидации Русского археологического общества (РАО) библиотека и архив учреждения поступили в РАИМК в 1925 г. В архив были переданы материалы четырех отделений РАО, протоколы Совета, общих собраний, рукописи докладов и статей членов РАО, годовые отчеты, материалы археологических исследований, дневники, рисунки, восточные рукописи, переписка о приобретении древностей и другие документы за 1846-1924 гг. Фотоматериалы лишь частично отражают работу Общества.

В этом же году в фотоархив ГАИМК было передано более 2 тысяч негативов фотосъемки рукописей, текстов, гравюр, портретов, разных предметов древности, снимки из раскопок Успенского собора во Владимире 1880-х гг., альбом с видами Кракова и фотографии с видами Польши из коллекции «бывшего» Санкт-Петербургского археологического института. Рукописные материалы Института оказались в другом хранилище.

В течение второй половины 1920-х гг. несколько раз предпринимались попытки изъять из архива Академии дореволюционные архивы и документы первых лет ее существования в Центрархив или в Ленинградское губернское архивное бюро, однако при поддержке Главнауки удалось отстоять право Академии и еще некоторых научных учреждений Ленинграда и Москвы на хранение архивных собраний в собственных архивах.

В 1929 г. в архив ГАИМК из Москвы перевезли материалы Московского археологического общества (МАО). Архив включал анкеты о «майданах» (1880-е гг.), анкеты 
для составления археологических карт губерний, церковные метрики северо-западных губерний (1890-е гг.), анкеты об архивах (1900-е гг.), черновики статей и рефератов сотрудников МАО, дела о сборе денег на памятники первопечатнику Ивану Фёдорову, патриарху Гермогену и архимандриту Дионисию, финансовая и хозяйственная переписка, библиографический карточный указатель, рукописи XVII-XVIII вв., фотографии, документацию по археологическим съездам, статьи членов МАО и других лиц, curriculum vitae сотрудников Общества. Часть документов после разборки была передана в другие учреждения.

В конце 1920-х гг. в ГАИМК также поступили материалы организаций, чья деятельность была связана с ликвидированным Ленинградским музейным фондом и другими расформированными учреждениями Главнауки в Ленинграде. Среди них были документы Общества защиты и сохранения в России памятников искусства и старины и Отдела по делам музеев и охране памятников искусства и старины при Наркомпросе, фотографии из хранения Музейного фонда и Ленинградских реставрационных мастерских, ранее в фотоархив приняли фотофонд Шуваловского дворца после закрытия находящегося там с 1919 по 1925 г. музея быта.

В 1930 г. прекратило свою деятельность издательство Комитета популяризации художественных изданий, состоявшее при ГАИМК, его материалы образовали два фонда. Рукописный фонд составили документы переписки, рукописи, корректуры изданий, в фотофонд вошли снимки 1890-1920 гг., унаследованные Комитетом от издательства Общины св. Евгении и Общества поощрения художеств в Петербурге.

Кроме всех уже перечисленных фондов организаций, материалы которых поступили в Архив ГАИМК в 1920-1930-х гг., в собрании архивных документов хранится большое количество сведений, которые могут послужить ценными источниками информации в деле восстановления судьбы вещественных и документальных коллекций Археологического института в Константинополе, Императорского Палестинского православного общества, Русского историко-генеалогического общества, Исаакиевского собора, Эрмитажа, Русского музея и других музейных и архивных собраний России.

\section{ЛИТЕРАТУРА}

Девель T.M., 1950. Обозрение коллекций собрания фотоархива Института истории материальной культуры им. Н.Я. Марра АН СССР // СА. Т. ХІІ. С. 289-336.

Платонова Н.И., 2010. История археологической мысли в России. Вторая половина XIX - первая треть XX века. СПб.: Нестор-История. 316 с.

Пескарёва К.М., Владимирова Т.T., 1980. Рукописные архивы Института археологии АН СССР // КСИА. Вып. 163. С. 87-92.

\section{ГОСУДАРСТВЕННЫЙ ИСТОРИЧЕСКИЙ МУЗЕЙ И СТАНОВЛЕНИЕ СОВЕТСКОЙ АРХЕОЛОГИИ В 1920-е ГОДЫ (ПО МАТЕРИАЛАМ ОТДЕЛА ПИСЬМЕННЫХ ИСТОЧНИКОВ ГИМ)}

Первое послереволюционное десятилетие было, пожалуй, самым сложным и противоречивым в истории Государственного (тогда Российского) исторического музея, насыщенным многими событиями и важными переменами, сыгравшими немалую роль в судьбах отечественной археологии. Для понимания этих процессов документы ОПИ ГИМ во многом играют ключевую роль: они дают возможность взглянуть на становление новой - советской - археологии через призму деятельности археологов крупнейшего национального музея России.

Для Исторического музея смена власти в октябре 1917 года не была вселенской катастрофой. Несмотря на холод, голод, потерю родных, неопределенность ситуации в 
стране в годы Гражданской войны для археологов РИМ (как и для большинства его сотрудников) главнейшим лейтмотивом их деятельности, их жизненной позицией являлось сбережение традиций русской науки и культуры. Директор музея князь Н.С. Щербатов, главный хранитель А.В. Орешников и один из ведущих сотрудников РИМ В.А. Городцов не могли не пойти на сотрудничество с советской властью и, прежде всего, с теми многочисленными комиссиями, которые в 1918-1921 гг. осуществляли реорганизацию музея. К концу 1921 г. была выработана и утверждена новая структура РИМ. Научные отделы объединились в шесть основных групп (разрядов). Вслед за перестройкой организационной структуры стало меняться и содержание всей деятельности музея. В 1921 г. князь Щербатов оставил свой пост (но остался членом коллегии); в дальнейшем директорами РИМ-ГИМ становились лояльные советской власти назначенцы (причем до 1930 г. сменилось 6 директоров).

Работа археологического разряда строилась на основе разработок и докладов Василия Алексеевича Городцова. С 1922 г. он стал председателем I археологического разряда (в него вошли отделы доисторической, раннеисторической и славяно-финской археологии). Разряд занимался научной обработкой коллекций и экспозиционной работой по эпохам и культурам до IX в. включительно. В залах произошли заметные изменения. Разработав периодизацию культур бронзового века юга и центра Восточной Европы, Городцов в начале 1920-х гг. развернул систематическую экспозицию по этому периоду в зале № 3. Это был показ базовых археологических культур, выделенных им к тому времени. Такой подход к постройке экспозиции сохраняется в ГИМ и в наши дни, он был взят на вооружение и в других музеях страны. Из академической, предназначенной для специалистов, экспозиция начала превращаться в общедоступную применительно к запросам широких трудящихся масс. В 1922 г. в РИМ был создан отдел популяризации музейных собраний, разработавший новые типы экскурсий. Разрабатывались новые методики, например, по теме «Использование археологического материала в просветительной работе», готовились к печати пособия «Теория и практика экскурсионного дела в области первобытной археологии», «Археологические таблицы для экскурсантов РИМ» и др. Стала налаживаться научная издательская деятельность: в 1926 г. вышел первый в советское время археологический сборник музея со статьями В.А. Городцова, А.А. Захарова и Б.Н. Гракова.

На всех этапах экспозиционной работы начала и середины 1920-х гг. самыми первыми и надежными помощниками Городцова были студенты-археологи 1 МГУ, а затем аспиранты Института археологии и искусствознания РАНИОН А.В. Арциховский, А.Я. Брюсов, С.В. Киселёв, А.П. Смирнов, Д.А. Крайнов, М.Е. Фосс и др. «Пожарная команда» Городцова (как окрестили его учеников в музее) в итоге почти в полном составе влилась в разные отделы музея. Эта команда составила костяк экспедиций, которые, начиная с 1924 г., когда к финансированию раскопок подключились Институт археологии и искусствознания (ИАИ) РАНИОН и Наркомпрос РСФСР, стали регулярными и достаточно масштабными. Коллекции из раскопок этих экспедиций (Галичской, Муромской, Средневолжской и пр.) и поныне принадлежат в ГИМ к числу базовых. После первых выездов в поле и проверки на профессиональную пригодность Городцов доверял ученикам самостоятельные разведки и раскопки.

В начале 1930-х гг. на долю воспитанников Городцова, увы, пришлась неблагодарная по отношению к учителю задача - провести полную реорганизацию экспозиции, научно-исследовательской работы и политико-просветительной деятельности под лозунгом «Лицом к политике, лицом к марксизму, лицом к массам». В первые месяцы 1929 г. в ГИМ работала комиссия по чистке аппарата Наркомпроса РСФСР и подведомственных ему учреждений. Она констатировала, что большая часть коллектива - это буржуазные специалисты, чуждые по отношению к советской власти, тяготеющие к сугубо академической деятельности, безучастные к задачам социалистической перестройки музея. Приказом Наркомпроса от 15.10.1929 г. было объявлено о ликвидации общеисторического отдела и об увольнении (в форме сокращения штатов и с формулировкой «по рационализации работы музея») значительной группы старейших сотрудников. В их 
числе - археологи В.А. Городцов, Ю.В. Готье, А.А. Захаров, Б.Н. Граков, О.А. Кривцова-Гракова, Ф.А. Афремова-Эдинг (всего 21 человек).

Сломана была и прежняя структура археологических отделов. Оставшиеся сотрудники, коллекции и функции были «распылены» по различным секторам. Вместо археологического отдела образован сектор истории развития общественных форм, состоявший из отделов доклассового общества (зав. А.Я. Брюсов), эпохи феодализации (зав. Е.Г. Пчелина), эпохи феодализма (зав. А.В. Арциховский). Кроме того, создан специальный сектор консультации по отраслям исторического быта, в котором специалист по античной археологии А.С. Башкиров был зачислен в отдел быта национальностей. Сектор диалектической истории техники состоял из лабораторий: жилища и обстановки, посуды и пищи, одежды и тканей, средств передвижения, оружия и военной техники (зав. П.А. Дмитриев), промышленной и научно-технической техники, а также экспертиз: дерева (Д.Н. Эдинг); металла, камня и силикатов (М.Е. Фосс); текстиля и кожи. Старая городцовская экспозиция - в ущерб оригинальным экспонатам - начала пополняться картами, рисунками, фотографиями, документами, картограммами, приборами и пособиями, якобы способствующими популяризации собрания древностей ГИМ. Лишь во второй половине 1930-х гг. ученикам Городцова удалось вернуться к традиционным формам музейного строительства.

РИМ-ГИМ на протяжении 1920-х гг. тесно сотрудничал с общероссийскими и московскими учреждениями и организациями. Несмотря на дефицит музейных площадей (музей принимал в те годы коллекции Государственного музейного фонда, ряда закрытых музеев, частных собраний), он предоставил свои помещения Археологическому подотделу Отдела по делам музеев и охране памятников искусства и старины (Музейного отдела) Наркомпроса РСФСР, Московской секции РАИМК-ГАИМК и ее научно-технической лаборатории тканей и шитья. Именно археологи РИМ спасали библиотеку и архив Московского археологического общества. После закрытия МАО в 1923 г. по постановлению Наркомпроса при музее было образовано филиальное отделение «Бывшее Московское археологическое общество». Одно из помещений музея занимало Общество друзей Исторического музея, председателем которого в 1922-1929 гг. был Городцов. Здесь постоянно выступали его студенты и аспиранты, сотрудники ИАИ РАНИОН и Московской секции РАИМК-ГАИМК, иностранные ученые (Г. Мергарт), проходили стажировку музейщики из провинции.

Одним из нововведений послереволюционного периода стало проведение музейных курсов, организованных Музейным отделом Наркомпроса. Чаще всего они проходили в РИМ-ГИМ, где была возможность сопровождать лекции с непосредственным ознакомлением с коллекциями. В 1919 г. состоялись курсы музееведения и музейной техники, на которых освещались вопросы распознавания музейного материала, его систематизации, описания и хранения. Практические занятия на курсах вели В.А. Городцов, И.Э. Грабарь, В.М. Фриче, И.А. Орбели, В.Г. Дружинин, А.А. Спицын, Д.Н. Анучин, В.К. Клейн. В 1921 г. на базе РИМ и Политехнического музея были организованы курсы по подготовке руководителей экскурсий по культурным и художественным ценностям города Москвы. Городцов вел на них краткий курс «История первобытной культуры», а также готовил инструкторов ГубОНО по охране и изучению археологических памятников. В 1926 г. на курсах по переподготовке музейных работников он прочел курс лекций о методах археологических исследований, правилах экспонирования, регистрации, консервации, хранения и каталогизации коллекций. Практические занятия со слушателями проводились в фондах и экспозиции ГИМ.

Важнейшую роль в текущей деятельности археологов музея в 1920-е гг. играло сотрудничество с Археологическим подотделом Музейного отдела Наркомпроса РСФСР, а также с ИАИ РАНИОН и Московской секцией РАИМК-ГАИМК. Связующим звеном во взаимодействии данных учреждений был Городцов. Во всех этих организациях он располагал административным ресурсом. Его пост руководителя Археологического подотдела (с 1918 по 1926 г.) фактически был сродни должности «государственного» археолога страны. Городцову пришлось участвовать в работе множества комиссий и уч- 
реждений (в том числе тех, что разрабатывали в этот период правовые, теоретические и методологические проблемы археологии), выступать с различными инициативами по реформированию музейного и археологического дела в стране. При отсутствии надлежащего штата в Археологическом подотделе его ближайшими помощниками и секретарями были бывшие ученики - сотрудники РИМ-ГИМ и ИАИ РАНИОН (Ф.А. Афремова-Эдинг, С.Г. Матвеев и др.).

Руководство археологическими отделениями 1 МГУ (1919-1930) и ИАИ РАНИОН (1923-1930) с опорой на Исторический музей как базу практических и научных занятий его студентов и аспирантов позволило Городцову коренным образом (по сравнению с Московским археологическим институтом и университетом имени А.Л. Шанявского) изменить систему профессионального археологического образования в Москве. Выпускники археологического отделения 1 МГУ 1920-х гг. А.В. Арциховский, О.Н. Бадер, А.Я. Брюсов, Е.В. Веймарн, Б.Н. Граков, П.А. Дмитриев, Л.А. Евтюхова, А.В. Збруева, С.В. Киселёв, Д.А. Крайнов, О.А. Кривцова-Гракова, Е.И. Крупнов, В.П. Левашева, Н.В. Пятышева, А.П. Смирнов, Б.А. Рыбаков, М.Е. Фосс и др. влились в штат ГИМ и других музеев, составили костяк аспирантов и сотрудников ИАИ, а в 1932 г. и Московского отделения ГАИМК.

Изначальное неустойчивое административное и финансовое положение Московской секции РАИМК-ГАИМК вынудило Городцова, поначалу возглавившего Комиссию по археологии Московской секции, покинуть ее в 1924 г. и направить все усилия на укрепление ИАИ РАНИОН. Его не устраивало подчиненное положение секции РАИМК перед головной частью Академии в Ленинграде. В тесной связке ИАИ и ГИМ, усиленной административным ресурсом Музейного отдела Наркомпроса РСФСР, Городцов выстраивал противовес РАИМК-ГАИМК. Он воспринимал Академию как преемницу Императорской археологической комиссии, а ИАИ - как продолжателя дела Московского археологического общества. В этой позиции были как свои сильные, но в большей степени слабые стороны. Соперничество ИАК и МАО не могло быть образцом в новых исторических реалиях. Необходима была работа по консолидации археологических сил страны и прежде всего археологов Ленинграда и Москвы. Выстроить противовес ГАИМК в Москве Городцову не удастся: ИАИ, как РАНИОН в целом, окажутся невостребованными в ходе перестройки гуманитарной науки на рубеже 1920-1930-х гг. и растворятся в других учреждениях. Ученый лишится в это время основных административных постов, станет в 1932 г. (ирония судьбы!) сотрудником Московского отделения ГАИМК (как и большая часть его учеников), а еще через год начнет тесно сотрудничать с Институтом антропологии, археологии и этнографии (МАЭ) в Ленинграде.

Тем не менее, административная, педагогическая и музейная деятельность Городцова в 1920-е гг. сыграла ключевую роль в судьбах не только московской, но и советской археологии в целом. Главное, что ему удалось в эти годы - влить свежую «кровь» в плохо структурированную и разношерстную среду археологов Москвы. Как педагог он выпестовал в 1 МГУ несколько выпусков талантливой, работящей и целеустремленной молодежи. Большинству учеников нашлась работа в Историческом музее, Институте и Музее антропологии МГУ, других музеях страны. ГИМ в те не самые простые в отношении трудоустройства времена оставался самым надежным прибежищем московских археологов. Многие выпускники Городцова стали аспирантами и сотрудниками ИАИ РАНИОН, работали здесь под его началом, овладели азами марсксистской социологии в семинаре В.М. Фриче и в дальнейшем составили костяк Московского отделения ГАИМК-ИИМК. Городцов воспитал не просто учеников, он воспитал поколение учителей. Почти за каждым из них своя научная школа (А.В. Арциховский, О.Н. Бадер, Б.Н. Граков, С.В. Киселёв, А.П. Смирнов, Е.И. Крупнов и др.) или направление исследований (А.Я. Брюсов, М.Е. Фосс, Д.А. Крайнов, А.В. Збруева, Б.А. Рыбаков и др.). Благодаря деятельности и трудам этих ученых сохранилась преемственность с дореволюционной русской археологией. Современная отечественная археология многими своими корнями прорастает из той живительной среды, что была взращена в 1920-е гг. в Государственном историческом музее. 


\section{АРХЕОЛОГИЧЕСКАЯ ДЕЯТЕЛЬНОСТЬ ТАМБОВСКИХ ЛЮБИТЕЛЕЙ СТАРИНЫ В НОВЫХ РЕАЛИЯХ: ОТ УЧЕНОЙ АРХИВНОЙ КОМИССИИ К КРАЕВЕДЧЕСКИМ ОБЩЕСТВАМ 1920-Х ГОДОВ}

До 1917 года большую роль в развитии тамбовской археологии играла Тамбовская ученая архивная комиссия (далее ТУАК), учрежденная одной из первых в империи (1884). В археологической деятельности ее, как и в остальных направлениях работы, прослеживаются два этапа: 1884-1899 гг. и 1900-1918 гг., содержание которых во многом предопределялось взглядами и исследовательскими интересами председателей И.И. Дубасова (1843-1913) и А.Н. Норцова (1859-1921).

Деятельность ТУАК по изучению тамбовского края в археологическом отношении сводилась к трем основным направлениям: проведение экскурсий (разведок) с целью выявления памятников старины, обобщение сведений о них в виде археологических карт, эпизодическое проведение раскопок (Захарова, 2015. С. 19-20). Комиссия также стала организатором губернского музея, в котором хранились и археологические находки. Однако гораздо большего размаха она добилась в области архивного дела, которое, судя по всему, и являлось для членов ТУАК приоритетным. Констатируя практически полное отсутствие произведенных силами комиссии сколько-нибудь масштабных раскопок, в то же время следует признать ее неоспоримый вклад в дело накопления и обобщения данных об археологических объектах края, сохранения археологического наследия в музейных фондах.

После революции 1917 года никаких распоряжений об упразднении архивных комиссий издано не было. Постепенно члены архивных комиссий включались в новые краеведческие структуры, создаваемые советской властью. Поэтому для 1920-х годов XX века уже характерна активизация краеведческих объединений нового формата, которые в условиях организационной беспомощности только что установившейся новой власти стремились обеспечить в должной мере охрану памятников прошлого, музеев, архивов.

В первые годы народной власти при Тамбовском университете возникло Общество истории, археологии и этнографии Тамбовского края, которое в 1924 г. было преобразовано в Общество изучения природы и культуры местного края. Условием для успешной деятельности этих объединений являлись, с одной стороны, активность их членов, а с другой - организационная работа Центрального бюро краеведения. Краеведческое движение молодого советского государства отличалось широким диапазоном тем и проблем.

Ведущей фигурой тамбовского краеведения стал П.Н. Черменский (1884-1973), для которого характерен широкий спектр исследовательских направлений. В историю археологии он вошел как первооткрыватель многослойной Периксинской стоянки и селища XVII века у с. Татаново Тамбовского района (Моисеев, 1999. С. 11). Другим краеведом, Н.Н. Дёминым, в 1927 г. были открыты недалеко от г. Мичуринска неолитические стоянки Подзоровская и Глинище (Моисеев, 1999. С. 29-30). Практически все вышеназванные памятники впоследствии обстоятельно исследовались специалистами.

Продолжал свою многогранную деятельность и лидер липецких краеведов М.П. Трунов, объединивший своих единомышленников в Общество изучения местного края (1919). Одним из ярких результатов его археологических занятий в этот период стало открытие знаменитой верхнепалеолитической Гагаринской стоянки, о котором он доложил на Первой тамбовской губернской краеведческой конференции по изучению производительных сил.

В это же время начинает активную работу исследователь старины П.П. Иванов создатель Моршанского историко-археологического музея (1918). Став его директором, он получил возможность собирать древности и производить археологические раскопки 
в родном уезде. В 1924-1925 гг. на стоянке Сокольники (правый берег р. Цны) им обнаружена неолитическая керамика, кремневые орудия; в 1927-1928 гг. на ЕлизаветМихайловском могильнике (правый берег р. Моршевки) исследовано 136 древнемордовских погребений VIII-XI вв., а в 1928 году в Пановском могильнике таковых выявлено 158; с 1929 г. он приступает к изучению Крюково-Кужновского могильника (правый берег р. Цны). Показательно, что в следующем, 1930 году, для руководства раскопками последнего был приглашен С.Н. Замятнин, который вскрыл здесь 10 захоронений. Данный могильник и на сегодняшний день является одним из наиболее крупных погребальных памятников древней мордвы.

Таким образом, можно констатировать, что ведущие представители Тамбовского краеведческого сообщества в первое послереволюционное десятилетие активно налаживали археологическую деятельность в родном крае. Однако после печально знаменитого Х Пленума Центрального бюро краеведения (1931) начинается разгром этого движения в Советском Союзе под лживыми предлогами «засоренности» его рядов буржуазнодворянско-поповскими элементами. Пострадало от репрессий и тамбовское краеведение. Примечательно, что преследование его началось, как и во всех областях Центрального Черноземья, уже с начала ноября 1930 г. в рамках так называемого «Дела краеведов» (Акиньшин, 1992. С. 208-235), то есть на два месяца раньше отмеченного Пленума. Лучшие представители сообщества, в том числе П.Н. Черменский, М.П. Трунов, были арестованы, а краеведческая работа на местах почти полностью угасла, и некоторое оживление ее произошло лишь более чем через три десятка лет.

\section{ЛИТЕРАТУРА}

Акиньшин А.Н., 1992. Трагедия краеведов (по следам архива КГБ) // Русская провинция. Воронеж. С. 208-235.

Захарова Е.Ю., 2015. История археологии Центрального Черноземья России (последняя четверть XVIII в. - 1970-е гг.). Автореф. дисс...д.и.н. Воронеж: ВГУ. 40 с.

Моисеев Н.Б., 1999. Археологические исследования в Тамбовском крае. Тамбов: Изд-во ТГУ. 54 с.

\section{ДОНСКИЕ АРХЕОЛОГИ В УСЛОВИЯХ «СОВЕТИЗАЦИИ» И ВРЕМЕНИ «ПОЛИТИЧЕСКОГО БАНДИТИЗМА»}

В ходе революции и Гражданской войны большинство археологов и краеведов России ответили на поставленные самой жизнью вопросы: «уезжать или остаться» и «хранить или увозить». В эти трагические годы сложилась определенная система взаимоотношений любых вариантов политических диктатур с системой учреждений, занимающихся археологическими исследованиями в провинции: от покровительственного отношения к музеям - до позитивно-нейтрального к учебным заведениям. В этой системе отношений музеи выступали, прежде всего, как места хранения материально и социально значимых предметов. Вторая характеристика иногда была даже более важна, чем первая. Так, в Донском музее в Новочеркасске хранились войсковые регалии, обладание которыми было основным идеологическим обоснованием прав казачества на политическую самостоятельность в пестром мире антисоветских партий и движений. Это подтверждает и судьба коллекции музея, вывезенной из Новочеркасска в декабре 1919 г., проделавшей «одиссею» по странам Европы и возвращенной на Дон в 1946 г. (Бойко, 2014. С. 235; Бойко, 2015. С. 188-190).

В остальных случаях, даже при репрессиях к членам музейного сообщества, дальше частных случаев краж во время активных военных действий или «установления власти» дело не шло. Любопытно, но некоторые музеи (Таганрог, Новочеркасск) даже по- 
полнили свои собрания за счет конфискованного «старого» оружия и других предметов, которые не имели явной материальной ценности или ликвидности.

Отношение властей к высшим учебным заведениям диктовалось стремлением стабилизировать взаимоотношения военно-политического руководства государственных структур Юга России и достаточно многочисленного здесь эвакуированного студенчества и профессуры, избегая форм крайнего обострения. Наличие действующих университета и институтов в условиях Гражданской войны рассматривалась, по крайней мере, на уровне агитации, как важный показатель стабильности государственных устоев. Формой определенного компромисса с университетским сообществом стало открытие институтов, действовавших на коммерческих началах. Это позволяло обойти строгие университетские уставы и правила, регламентирующие требования к уровню базовой подготовки абитуриентов и состав учебных программ. Высокий количественный уровень набора определялся и льготами по отношению к действительной военной службе. В этих условиях и действовал открытый в 1918 г. Донской археологический институт (Римская, 1999. С. 70 и сл.).

Только общественные организации, среди которых видное место занимали краеведческие общества, бывшие по большей части прибежищем носителей либеральнодемократических настроений, вызывали острое недоверие практически любого политического режима. С 1920 г. на Дону начинается полоса мероприятий победившей власти в области культуры и образования, проходившей под знаменем «советизации». Под этим термином понимается механизм решения комплекса проблем восстановления всех форм государственных институтов и хозяйства страны с идейных позиций политического руководства победившей стороны - Советской России (Бойко, 2014. С 234-240). Пик «советизации» в области культурного строительства пришелся на 1920-1923 гг., однако окончание этого периода связано с завершением очередного цикла территориальноадминистративных реформ 1925-1926 гг.

В новых условиях основным координирующим центром, в компетенцию которого попали и все формы археологической деятельности в провинции, стали учреждения народного образования. Непоследовательность и ярко выраженный волюнтаристический характер ряда решений органов, управлявших культурным строительством на Дону в 1920-1924 гг., их выраженная сиюминутная политическая ангажированность, заставляют усомниться в существовании какого-либо научно-обоснованного планирования в этой области. Многочисленные просчеты в организации музейной работы, пренебрежительное отношение к ряду памятников культурного наследия и фактическая ликвидация прежней структуры организации взаимодействия государственных учреждений и общественных институций стали приметой времени. Подтверждением этого является судьба ряда региональных музеев, открытие и быстрая ликвидация которых пришлась на 19211923 гг. (Коневская, 1989. С. 156-164).

Другим полюсом этих мероприятий стало неумеренное прожектерство в области строительства новой вертикали учреждений образования и культуры, призванных заниматься изучением древностей края, сосредоточенных в специальном «Дворце искусств». В условиях ограниченного финансирования единственным методом всевозможных оптимизаций считалось максимальное укрупнение центральных структур при неизбежном увеличении аппарата управления.

Возможность проведения полевых археологических работ в действительности определялась военно-политической обстановкой в крае, которая характеризовалось как время «политического бандитизма». Любые стационарные раскопки на значительном отдалении от городских центров были просто опасны для жизни, редким исключением стали научные экскурсии обзорного характера (Бойко, 2017. С. 19-21).

В этой ситуации стала складываться система определенного разграничения возможных сфер деятельности в археологических исследованиях. Диктат государства в образовании привел к ликвидации Донского археологического института, а позднее и преподавания дисциплин конкретно-исторического профиля в Донском университете. Возможность прикладных занятий археологией была ограничена разведками и наблюде- 
ниями инициативного характера или участием в заседаниях Донского общества археологии и истории искусств, - организации, не имевшей собственного научного издания и постепенно утратившей все материальные активы и коллекции. Возможность проведения самостоятельных раскопок теперь определялась степенью участия местных специалистов в крупных государственных научно-исследовательских проектах, важнейшим из которых стало начало работ Северо-Кавказской экспедиции РАИМК в 1923 году и лояльность ее руководству (Бойко, Толочко, 2017. С. 589).

\section{ЛИТЕРАТУРА}

Бойко А.Л., 2014. О механизмах «советизации» музеев Дона (1920-1924 гг.) // Краеведческие записки. Сборник научных трудов. Вып. 11. Новочеркасск. С. 234-240.

Бойко А.Л., 2015. Музей в русской Вандее (Архивные данные о работе Донского музея в годы Гражданской войны) // Архивы и архивное дело на Юге России: история, современность, перспективы развития. Материалы Всероссийской научной конференции 16-17.10.2015 г. Ростов-на-Дону. С. 185-191.

Бойко А.Л., 2017. О нижней хронологической границе «советского» периода в истории донской археологии // «Проблемы археологии Восточной Европы и Дальнего Востока». Материалы XII Международной археологической конференции студентов и аспирантов (Ростов-на-Дону, 26-29.11.2017 г.). Ростов-на-Дону-Таганрог. С. 16-24.

Бойко А.Л., Толочко И.В., 2017. Донская археология на переломе эпох: 19171930 гг. // Материалы Всероссийской научной конференции «Юг России в условиях революционных потрясений, вооруженных конфликтов и социально-политических кризисов, 1917-2017 гг.», ИСЭГИ РАН-ЮНЦ РАН, 05-06.10.2017. С. 580-592.

Коневская Т.И., 1989. Первые мероприятия по организации музейного строительства на Дону (1920-1923 гг.) // Известия Ростовского областного музея краеведения. Вып. 6. С. 155-164.

Римская 3.Н., 1999. Донской археологический институт // Донская археология. № 2. C. 69-76.

\section{У ИСТОКОВ СОВЕТСКОЙ АРХЕОЛОГИИ: КРАСНОЯРСКИЙ МУЗЕЙ В 1920-е ГОДЫ (К 130-ЛЕТИЮ КРАСНОЯРСКОГО КРАЕВЕДЧЕСКОГО МУЗЕЯ)}

Новые исторические реалии, сложившиеся в Сибири после окончания Гражданской войны, определили особенности становления региональной археологии в Приенисейском крае. С 1903 г. музей подчинялся Красноярскому подотделу Русского географического общества (КОРГО).

В январе 1920 г., с установлением советской власти в Красноярске, ситуация вокруг музея изменилась: подотдел РГО фактически находился на нелегальном положении, а новые власти не торопились его поддерживать. Музей переходит в ведение Енисейского губернского отдела народного образования (ЕнГубОНО).

В новых условиях КОРГО ведет поиск иных путей решения вопросов организации научных исследований. На заседании 5 марта 1920 г. распорядительный комитет рассмотрел проект И.И. Ульянова об открытии в Красноярске историко-этнографического общества. Против этого предложения высказывается большинство членов комитета, так как цели, намеченные для нового Общества, уже осуществляло КОРГО (ГАКК. Ф. 1380. Оп. 1. Д. 2. Л. 8-8 об.). Таким образом, КОРГО по-прежнему пыталось сохранить за собой право организации всестороннего изучения губернии, в том числе археолого-этнографического направления.

У истоков советской археологии в Красноярске оказались иностранные специалисты. В 1919-1921 гг. в Красноярском городском музее плодотворно работает пленный 
австрийский археолог Г. Мергарт. Ему принадлежит не только идея создания специализированного археологического отдела, но и детальное обоснование его деятельности. (НА КККМ. Оп. 1. Д. 570. 5 л.) В итоге инициатива Г. Мергарта была реализована на практике. Совместно Г.П. Сосновским и А.Я. Тугариновым начаты масштабные разведочные работы по Енисею. Г. Мергартом была подготовлена новая археологическая выставка в музее (Детлова, Макаров, Эренфрид, 2005).

Вместе с тем, в условиях неопределенного положения КОРГО, 25 марта 1920 г. Институтом исследования Сибири (ИИС) было предложено открыть в Красноярске Приенисейское отделение и информировать об этом ГубОНО (ГАКК. Ф. 1380. Оп. 1. Д. 2. Л. 10). Еще в 1918 г. на заседании распорядительного комитета КОРГО консерватор Красноярского музея А.Я. Тугаринов отмечал: «В настоящее время не функционирует ни Петроградская археологическая комиссия, которая давала разрешения на производство археологических раскопок по всей России, ни ученая архивная комиссия, в которой было сосредоточено управление русскими архивами... Вследствие отсутствия какой-либо охраны - памятники старины погибают. Было бы своевременным поручить охрану памятников исторических, археологических и палеонтологических местным отделам Географического общества, от которых бы зависело разрешение на раскопки и проч.» (Свободная..., 1918). Но уже 2 июля 1920 г. в г. Томске ИИС был закрыт.

В конце лета 1920 г. Научный отдел Наркомпроса РСФСР сообщил, что отделы Русского географического общества как составные части этого учреждения подведомственны только Наркомпросу, в ведении которого РГО состоит. Никакое разделение означенных отделов между другими учреждениями или изъятие от них библиотек, музеев, научных коллекций и материалов допущено быть не может без разрешения Наркомпроса (ГАКК. Ф. 1380. Оп. 1. Д. 6. Л. 4).

На основании этого красноярская организация зарегистрировалась как Красноярский отдел РГО (КОРГО). Однако местные власти реагировали по-своему: музеи, здания, коллекции и библиотеки, ранее принадлежащие местным отдела РГО, были изъяты наробразами в Омске, Иркутске, Семипалатинске, Красноярске (ГАРФ. Ф. А-2307. Оп. 2. Д. 69. Л. 107).

Активно сотрудничал музей Приенисейского края с КОРГО, сотрудники которого были также и членами этого общества. При музее на протяжении нескольких лет периодически функционировала коллегия музея - своеобразный Ученый совет. На его заседаниях выступали с научными докладами сотрудники музея, члены КОРГО, а также приезжавшие в Красноярск ученые. Особо значимыми в 1921 г. стали выступления Г. Мергарта (22 марта) и С.А. Теплоухова (23 октября). Исследователи, независимо друг от друга, пришли к выводу о существовании самобытной андроновской культуры. Кроме того, С.А. Теплоухов выделил афанасьевскую культуру и культуру гробниц (ГАКК. Ф. 745. Д. 5. Л. 41-42).

В августе 1921 года в городе Новониколаевске на заседании Сибревкома обсуждался вопрос «о временном закрытии» географических обществ в Сибири. В дело вынужден был вмешаться Нарком просвещения А.В. Луначарский (ГАКК. Ф. 1380. Оп. 1. Д. 13. Л. 24).

Но даже московское начальство не могло решить все вопросы. На заседании коллегии ЕнГубОНО 28 апреля 1922 г. в очередной раз рассматривался вопрос о Красноярском музее. После доклада о переходе музея в ведение Академического центра Наркомпроса РСФСР было принято постановление: музей Приенисейского края по-прежнему следует считать находящимся в ведении ЕнГубОНО. Музей в данной ситуации выиграл, так как было решено «увеличить недостаточность кредитов» и «установить штаты музея в 10 человек... на снабжение из местных средств» (ГАРФ. Ф. А-2307. Оп. 3. Д. 348. Л. 97).

А.Я. Тугаринов, подводя итоги работы в новых условиях, отмечал: «... Музей, как и все учреждения, в связи с присоединением Сибири к Советской России, оказался накануне коренных изменений в условиях своего существования... он стоит на пути широких возможностей, имеет силы, средства. Как пойдет его жизнь, поскольку удастся осуществить давно ожидаемые планы... - об этом мы узнаем из отчета следующего года» (Красноярский ..., 1920). 


\section{ЛИТЕРАТУРА}

Детлова Е.В., Макаров Н.П., Эренфрид А.Г., 2005. Мергарт и Красноярский музей // Археология Южной Сибири: идеи, методы, открытия. Красноярск: РИО КГПУ им. В.П. Астафьева. С. 268-270.

Свободная..., 1918. Газета «Свободная Сибирь» от 21 декабря 1918 г. № 180 (392).

Красноярский..., 1920. Газета «Красноярский рабочий» от 2 ноября 1920 г.

А.А. Евгеньев

(Оренбург)

\section{ОРЕНБУРГСКОЕ ОТДЕЛЕНИЕ МОСКОВСКОГО АРХЕОЛОГИЧЕСКОГО ИНСТИТУТА: ОПЫТ ОРГАНИЗАЦИИ ПРОФИЛЬНОГО ОБРАЗОВАНИЯ В ПРОВИНЦИИ В НАЧАЛЕ 1920-х ГОДОВ}

Работа выполнена при поддержке Задания № 33.1389.2017/ПЧ на выполнение научно-исследовательской работы в рамках проектной части государственного задания в сфере научной деятельности Министерства образования и науки Российской Федерачии, и при поддержке проекта РФФИ «Древности» № 18-09-40031.

События 1917-1919 годов, связанные с установлением советской власти в Оренбуржье, имели необратимые последствия для культурной и научной деятельности в регионе. Прекратил свое существование местный центр изучения истории и археологии Оренбургская ученая архивная комиссия (ОУАК), многие из ее деятелей покинули губернию. Для ликвидации образовавшегося исследовательского дефицита перспективной могла оказаться деятельность учебного заведения, возникшего в Оренбурге весной 1921 года - Оренбургского отделения Московского археологического института (далее - ОО МАИ).

Московский археологический институт - образовательное учреждение, существовавшее в 1907-1922 гг. Несмотря на «археологическое» название, выпускал он главным образом архивистов. В то же время там до 1915 года преподавал В.А. Городцов, а среди выпускников были В.В. Гольмстен, П.С. Рыков, Д.Н. Эдинг и другие известные археологи. Особенностью института являлось наличие филиалов в различных городах России - Витебске, Калуге, Воронеже, Смоленске, Нижнем Новгороде, Ярославле, Ростове (Платонова, 2010. С. 201-202; Смирнов, 2011. С. 103-104).

Инициатива открытия отделения МАИ в Оренбурге, с 1920 года являвшемся столицей новообразованной Киргизской АССР, принадлежала представителям Общества изучения Киргизского края и Кирнаркомпроса. Эта идея нашла поддержку в МАИ: распространение образования в КАССР, к тому же с учетом сохранившейся организационной базы ОУАК (архив, музей, библиотека), могло представляться вполне перспективным начинанием. Было разработано «Положение об Оренбургском отделении Московского археологического института», декларировавшее, что «Оренбургский археологический институт есть высшее учебное заведение, имеющее целью научную разработку археологии, археографии, этнографии и истории края, а равно и подготовку специалистов для работы в архивах, музеях, библиотеках, а также преподавателей истории и родиноведения〉 (ГАОО. Ф. Р-469. Оп. 1. Д. 68. Л. 69-70). Предполагалось 4-летнее обучение, при котором на четвертый год учащиеся должны были написать и защитить диссертацию. В отличие от столичного вуза, в ОО МАИ было «временно» закрыто археографическое отделение, но вместо него планировали открыть отделение этнографическое. Кроме того, институт должен был приступить к научной работе «по собиранию, классификации и изучению материалов по этнографии, искусству, архивному делу, к созданию центральных и местных музеев и архивов, к производству археологических раскопок и к географическим и антропологическим обследованиям края» (ГАОО. Ф. Р-469. Оп. 1. Д. 68. Л. 75). 
Ректор МАИ А.И. Успенский в мае 1921 г. представил в Кирглавпрофобр свои соображения об организации образования в ОО МАИ (ГАОО. Ф. Р-469. Оп. 1. Д. 68. Л. 75-76, об). Список преподаваемых в этом вузе дисциплин в целом соответствовал списку дисциплин в МАИ. Предполагалось, что основные и специальные курсы будут читать профессора МАИ и отчасти оренбургские сотрудники (были расписаны кадры по 59 преподаваемым дисциплинам). Реальность оказалась гораздо прозаичнее амбициозного прожекта А.И. Успенского.

10 мая 1921 г. состоялось первое заседание Совета преподавателей МАИ, на котором от головного вуза присутствовали А.И. Успенский, С.Н. Ташкин, И.Ф. Колесников, Н.М. Коробков. На этом и последующих заседаниях был определен кадровый состав лекторов, главным образом оренбургских, преподающих 20 из 59 озвученных в плане А.И. Успенского дисциплин. К декабрю 1921 г. в списке сотрудников ОО МАИ числилось 11 лекторов (А.П. Мелков - проректор, К.К. Садовский, А.П. Гра, А.П. Лошкарев, Н.И. Бутовский, Н.В. Беневоленский, В.Я. Струминский, Н.А. Лебедев, Каршаубаев, Л.В. Лазова, Л.Л. Курашкевич), 2 научных сотрудника (И.И. Третьяков и А.В. Затаевич) и 8 служащих (ГАОО. Ф. Р-469. Оп. 1. Д. 71. Л. 1). В этом же списке фигурируют и приглашенные лекторы: А.И. Успенский, В.К. Заднепровский, Н.М. Коробков, В.М. Бардыгин. Однако по архивным данным невозможно установить, проводились ли ими занятия; в расписании занятия по их предметам отсутствуют.

Летом 1921 г. ОО МАИ обратилось в Общество археологии, истории и этнографии при Самарском университете с просьбой о проведении лекций. Свои услуги предложили А.С. Башкиров, Н.С. Лыкошин и П.А. Преображенский. Последний в дальнейшем от преподавания отказался, сославшись на тяжелое состояние железнодорожного сообщения между Самарой и Оренбургом. В.В. Гольмстен отказалась от сотрудничества с ОО МАИ из-за загруженности полевыми работами по археологическому обследованию Самарской губернии (ГАОО. Ф. Р-469. ОП. 1. Д. 68. Л. 3, 47). В итоге единственным археологическим компонентом в образовании слушателей ОО МАИ была часть курса А.П. Чулошникова по истории киргизского (казахского) народа (опубликован в 1924 году), посвященная древней истории Киргизского края.

В общей сложности в списках обучающихся в ОО МАИ фигурируют 108 студентов, из них 48 обучались на археологическом факультете, 50 на факультете истории искусств, а 10 вольных слушателей посещали лекции обоих факультетов с целью выбора какого-то одного (ГАОО. Ф. Р-469. Оп. 1. Д. 71. Л. 1). Однако организационные трудности (нехватка специально оборудованных помещений, отсутствие учебных пособий, проблемы финансирования и т.д.) не способствовали нормальному функционированию вуза. По сути, единственным крупным научным деянием ОО МАИ стала публикация в его «Записках» монографии С.Н. Ташкина «Инородцы Поволжско-Приуральского края и Сибири по материалам Екатерининской законодательной комиссии».

В весеннем семестре 1922 года зачеты были назначены на период с 15 мая по 1 июня, и было принято решение «прием новых студентов открыть и их зачислить, но права вступления в члены КОВУЗ до осени не давать» (ГАОО. Ф. Р-469. Оп. 1. Д. 68. Л. 75). Набор в итоге так и не состоялся, а летом 1922 года Московский археологический институт был ликвидирован и включен в состав факультета общественных наук Московского университета.

\section{ЛИТЕРАТУРА}

Платонова Н.И., 2010. История археологической мысли в России. Вторая половина XIX - первая треть XX века. СПб.: Нестор-История. 316 с.

Смирнов А.С., 2011. Власть и организация археологической науки в Российской империи (очерки институциональной истории науки XIX - начала XX века) / Отв. ред. И.В. Тункина. М.: Институт археологии РАН. 592 с. 


\section{ГОСУДАРСТВЕННЫЕ УЧРЕЖДЕНИЯ ТВЕРСКОЙ ГУБЕРНИИ: ВОЗМОЖНОСТИ АРХЕОЛОГИЧЕСКИХ ИССЛЕДОВАНИЙ}

В 20-х годах ХХ века в Твери развернулось довольно мощное краеведческое движение. Общество по изучению Тверского края, общественная организация с отделениями, созданными как в губернском центре, так и уездных городах, проводило разведки и раскопки памятников, публиковало отчеты. Лидерами этого движения были сотрудники губернского музея и преподаватели педагогического института.

Тверской музей, основанный в 1866 г. на общественных началах, в 1918 г. стал государственным учреждением. Должность заведующего музеем с 1918 по 1929 г. исполнял И.А. Виноградов, исследователь с многолетним опытом работы в дореволюционных краеведческих организациях. Поскольку основное внимание в работе музея теперь должно было быть уделено общественно значимым для революционного времени темам в истории края, археологические памятники изучались в рамках истории материальной культуры. Количественно эти работы были сведены к минимуму. За все десятилетие двое сотрудников музея - И.А. Виноградов и Ф.И. Иванов - раскопали всего 25 курганов. В плане полевой методики использовались наработки дореволюционного периода: насыпи копались широкими траншеями до погребения, рядом с курганами закладывался разведочный шурф.

Тверской педагогический институт был открыт по инициативе губернских преподавателей в период между двумя революциями - 2 ноября (21 октября по старому стилю) 1917 г. И по количеству учащихся (несколько десятков человек), и по преподавательскому составу (в основном преподаватели тверских гимназий и училищ) это было довольно скромное учебное заведение. В первые годы своего существования оно испытывало самые острые материальные трудности: отсутствие собственного здания, учебных пособий, денег на коммунальные услуги, оплату работы преподавателей и обеспечение продовольствием студентов (Баринова, Б/д). В вузе готовили учителей по основным отраслям знания: гуманитарные дисциплины, естественные и точные науки. Изучение исторических дисциплин предполагалось на социально-историческом факультете (1917-1924), позднее преобразованном в отделение языка и литературы (1925-1930) и с 1930 г. - на историкоэкономическом отделении общественно-литературного факультета.

Близость двух столиц сыграла положительную роль в развитии культурнопросветительных учреждений города. В пединститут приезжали читать лекции преподаватели из Москвы (в большей степени) и (в меньшей степени) из Петрограда. Исторические дисциплины преподавали Н.П. Грацианский, С.Д. Сказкин, И.Н. Радциг. Наиболее яркой фигурой среди местных преподавателей был краевед, выпускник СанктПетербургского университета А.Н. Вершинский. С 1922 по 1930 г. он руководил работой отделения языка и литературы.

Сразу же после Октябрьской революции начались существенные изменения в области исторического образования. Вместо гражданской истории было предложено изучать историю труда и социологию. Историю как учебный предмет заменили курсом обществоведения, в рамках которого остались лишь отдельные элементы курса истории с новым отбором фактов и их марксистским освещением. Но эти новшества не так быстро доходили до губернских вузов. Наиболее объемно дисциплины исторического цикла читались в Тверском пединституте в первой половине 1920-х гг. Например, программа на 1922/23 учебный год включала курсы по древней истории (первобытная культура, история Востока, Греции и Рима), по отечественной истории (в том числе и местного края), занятия по теории и методике истории (методика, методология и философия истории, историография) и т.Д. (ГАТО. Ф. Р-1213. Оп. 1. Д. 10. Л. 2). Курс истории первобытного общества предусматривал знакомство с археологическими памятниками и определение их роли в изучении древних обществ. 
Однако ведущее место в обучении гуманитариев в Тверском пединституте занимали занятия по краеведению. История края изучалась анкетным, экскурсионноэкспедиционным и стационарным методами; предполагалось использование как письменных, так и вещественных источников (ГАТО. Ф. Р-1213. Оп. 1. Д. 66. Л. 125). Практиковалось проведение занятий по истории края в залах губернского музея, богатых археологическими коллекциями, сформированными в дореволюционное время; чтение публичных лекций; занятия студентов в библиотеке и фондах музея. В докладной записке, составленной А.Н. Вершинским по поводу преподавания курсов краеведения в 1927/28 учебном году, приводился план мероприятий по подготовке студентов к самостоятельной работе (ГАТО. Ф.Р-2691. Оп. 1. Д. 53). Он включал в себя два основных этапа: проведение экскурсий и организацию экспедиций. Экскурсии предполагались для студентов младших курсов. По мере усложнения программы старшекурсники могли уже практиковаться в выездных экспедициях. Студенты-гуманитарии принимали активное участие в работе Верхневолжской этнологической экспедиции Российской академии материальной культуры и Верхне-Моложской экспедиции, организованной в тесном взаимодействии с Ассоциацией по изучению производительных сил российского Центра. В задачи экспедиции входило изучение лесного и травяного покрова, крестьянского хозяйства, промыслов (Вериинский, 1927), сбор этнографического материала. В 1927 г. были проведены обследования в районе озера Селигер, в 1928 г. - в Тверском и Кимрском районах, в 1929 г. - в Вышневолоцком районе (ГАТО. Ф. Р-1213. Оп. 1. Д. 46. Л. 99).

С 1922 г. на базе пединститута начало работать Тверское отделение общероссийской организации - Секции научных работников - профессионального союза, основной задачей которого было осуществление государственного контроля деятельности научной интеллигенции страны. В состав союза входили преподаватели и сотрудники высших и средних специальных учебных заведений, губернского музея, архива, а также исследователи, ведущие индивидуальную научную деятельность. На протяжении 1920-х гг. количественный состав организации принципиально не менялся: в ней состояло около 50 человек. К концу десятилетия в протоколах заседаний и отчетах о работе Секции все более стал ощущаться идеологический контроль партийных структур. Организационно это выразилось в исключении в 1927 г. заведующего Тверским музеем И.А. Виноградова, арестованного по политическим мотивам. В 1929 г. был снят с заведования кафедрой А.Н. Вершинский, также бывший член Тверской ученой архивной комиссии. С начала 1930-х гг. Тверское отделение Секции научных работников уже полностью подчинено задачам внедрения в научную среду региона марксистско-ленинской идеологии. Партийное руководство стремится регламентировать, в числе прочих сфер жизни, и творческую деятельность научной интеллигенции. Например, индивидуальный годовой отчет о научной работе предусматривал жесткую схему, состоящую из нескольких основных аспектов: преподавание отдельных дисциплин, воспитательная работа среди студентов, общественная работа. Научный работник был обязан применять марксистско-ленинские идеологические установки, использовать политехнизм в преподавании, принимать участие в соцсоревновании. Непосредственно содержанию научно-исследовательской работы был отведен самый последний пункт - № 11, который состоял из самой краткой формулировки: «Ваша научно-исследовательская работа» (ГАТО. Ф. Р-1213. Оп. 1. Д. 146. Л. 254).

Во второй половине 20 -х гг. ХХ в. интерес к изучению археологических памятников на территории губернии начинают проявлять профессиональные исследователи. Преимущественно это археологи из МГУ и ГИМ: Б.С. Жуков, Л.А. Евтюхова, М.Е. Фосс. В этот период взаимодействие местных и столичных исследователей только начинает формироваться. Наиболее полноценно оно разворачивается в последующее десятилетие в экспедиционной деятельности на территории Тверской губернии.

Таким образом, поскольку идеологическое влияние правящей партии (особенно в первой половине 1920-х гг.) еще не было настолько сильным, как впоследствии, в области изучения археологии края была возможность, с одной стороны, активно использовать лучшие достижения дореволюционного времени, с другой стороны - попытаться реализовать новые образовательные проекты на базе вновь открытого пединститута. 


\section{ЛИТЕРАТУРА}

Баринова Л.П., Б/д. Мои воспоминания о строительстве Тверского (Калининского) пединститута и первых шагах его существования (1917-1920 гг.). Б/д.

Вершинский А.Н., 1927. Промыслы Помоложья // Верхнее-Моложская экспедиция (1925-1926). Вып. 1: Лесная деревня / Под ред. А. Вершинского и А. Ильинского. Тверь:

Тверской пед. институт: Ком. Ассоциации по изучению производительных сил Тверской губ.

https://doi.org/10.25681/IARAS.2019.978-5-94375-275-9.23-24

Е.Ю. Захарова, М.В. Бояркин

(Воронеж)

\section{«...РАБОТА ВЕЛАСЬ НАСТОЛЬКО ИНТЕНСИВНО И БЫЛА ТАК ТЯЖЕЛА...»: О МУЗЕЙНОЙ АРХЕОЛОГИИ В ВОРОНЕЖСКОЙ ГУБЕРНИИ 1920-Х ГОДОВ}

В бурную пору революционных потрясений и Гражданской войны воронежские любители старины добровольно приняли на себя заботу о сохранении музейных, в том числе и археологических коллекций. С осени 1918 года это подвижничество получает мощный импульс, который был дан, с одной стороны, декретами новой власти об охране культурного наследия, а с другой - включением Воронежского музея в разряд государственных учреждений с содержанием сотрудников и выплатой заработной платы. В это время в Воронеже, к сожалению, на очень короткий период (ноябрь 1918 - сентябрь 1919 гг.) образовался продуктивный альянс новой власти и объединения энтузиастов (сотрудников музея и ученых вновь образованного университета), понимавших всю важность и своевременность охранных акций. Как уже было подмечено, именно фонды, самая консервативная и самая важная составная часть всякого музея, стали своеобразным вещным проводником между эпохами, обеспечив культурную преемственность музейных традиций (Котлярова, 2008. С. 111). Сосредоточив в своих руках огромные ценности, среди которых по-прежнему преобладали археологические коллекции, губернский музей, однако, не мог в условиях выживания их должным образом учесть и обработать.

В первой половине 1920-х гг. в Воронежской губернии, как и во всей центральной России, происходит формирование советской музейной системы и, соответственно, археологии в ней. Складывается государственная музейная сеть Наркомпроса РСФСР и часть музеев края определяется на твердый бюджет, формируется и перераспределяется музейный фонд, возобновляется экскурсионная и издательская деятельность, организуются ежегодные археологические и этнографические экспедиции (С.Н. Замятнин, Д.Д. Леонов, М.Е. Фосс, Т.М. Олейников, Н.В. Валукинский, В.К. Быстржинский, Г.В. Ерёменко). В этот процесс включились учрежденные еще до революции Воронежский губернский (1894) и Острогожский (1907) музеи. В первом из них был восстановлен и активно развивался под руководством С.Н. Замятнина отдел первобытных древностей; во втором - сбор, учет и хранение археологических находок продолжал осуществлять опытный музейный сотрудник Г.В. Еременко. Вместе с тем, в уездных городах возник совершенно новый тип музея - хранилище национализированных ценностей и гаранты их сохранения: Усманский народный музей (1918), Задонский историкоархеологический музей (1919), Богучарский государственный музей (1922), Алексеевский районный краеведческий музей при школе второй ступени (1923), Павловский музей местного края (1924). В каждом из них накапливались и археологические находки. К середине 1920-х годов сложившаяся еще до революции просветительская модель провинциального музея достигла своего расцвета.

Во второй половине 1920-х годов происходит реструктуризация музейной системы в масштабах всего государства с целью принципиального изменения ее функции в обществе. От музейных деятелей требовалось научную работу, в том числе и в области археологии, перестроить, исходя из методологических основ марксизма-ленинизма, а в 
просветительской - перейти от «культурничества» к политическому просвещению народных масс. Но традиционно мыслящие сотрудники не поддавались «основательной и систематической» переподготовке. Соответственно, следующей задачей для власти при перестройке музейной системы стала смена кадров.

Первая «мягкая» чистка руководящего состава Воронежского музея и, что показательно, университета была проведена одновременно в 1925 году (смещен с поста ректора университета В.Э. Регель, отстранен от должности заведующий музеем М.К. Паренаго). Тогда же музей претерпел реорганизацию, в ходе которой, что для нас важно, отдел первобытных древностей утратил самостоятельность.

Как известно, с 1927 года начинается ожесточенная борьба между Главнаукой и Главполитпросветом за влияние в музейной сфере. Краеведческие музеи должны были стать политико-просветительными учреждениями. В 1930 году в Воронеже прошел съезд краеведов Центрально-Чернозёмной области, где были публично разоблачены «лжекраеведы», а краеведческое объединение переименовано в Общество по изучению местного края в целях социалистического переустройства страны. По сфабрикованному местному «делу краеведов» начались аресты, и в мае следующего года коллегией ОГПУ был вынесен обвинительный приговор, в том числе и одиннадцати музейным сотрудникам Воронежской области (Акиньшин, 1992). После этого процесса на всю Воронежскую область остался один местный археолог с открытым листом - Н.В. Валукинский. В 1930-е годы археологические исследования в крае велись в основном уже силами ленинградских ученых (П.П. Ефименко, В.И. Равдоникас, Г.В. Подгаецкий, П.Н. Третьяков).

\section{ЛИТЕРАТУРА}

Акиньшин А. Н., 1992. Трагедия краеведов (по следам архива КГБ) // Русская провинция. Воронеж. С. 208-235.

Котлярова И. В., 2008. Музеи Воронежского края (вторая половина XIX - первая треть ХХ вв.). Воронеж: ВГУ. 163 с.

https://doi.org/10.25681/IARAS.2019.978-5-94375-275-9.24-26

А.Р. Канторович

(Москва)

\section{К ПРЕДЫСТОРИИ КАФЕДРЫ АРХЕОЛОГИИ ИСТОРИЧЕСКОГО ФАКУЛЬТЕТА МГУ}

В 2019 г. исполняется 80 лет кафедре археологии исторического факультета МГУ имени М.В. Ломоносова, основанной в 1939 г. выдающимся советским археологом А.В. Арциховским. Вместе с тем истоки преподавания археологии в МГУ связаны еще с началом XIX века.

Согласно Университетскому Уставу от 5 (17) ноября 1804 года в системе Московского университета в числе четырех Отделений или Факультетов создавалось Отделение словесных наук, на котором, помимо прочего, был учрежден курс (или кафедра, в терминах того времени) «теории изящных искусств и археологии». В рамках этого курса преподавалось преимущественно искусствоведение, и лишь в связи с ним затрагивались определенные вопросы, соотносимые с археологией в современном понимании (раздел исторической науки, основанный на изучении вещественных источников). При этом изначально речь шла исключительно о памятниках древнегреческого и древнеримского искусства. Но уже в 1832-1835 гг. в рамках курса «Археология, или История изящных искусств по памятникам», читаемого Н.И. Надеждиным - известным философом, историком, этнографом и литературным критиком, занявшим кафедру в декабре 1831 г., - помимо классической античности, появилась тематика древнейших произведений искусства других народов и цивилизаций, в частности Индии.

К несомненным заслугам кафедры теории изящных искусств и археологии следует отнести формирование университетской коллекции археологических материалов, в том 
числе связанных с экспедициями. Еще в начале 1830-х гг. крупный философ, литературовед и поэт С.П. Шевырёв, планировавший занять эту кафедру (но в итоге читавший лекции на кафедре истории российской словесности), выступил с проектом учреждения при Московском университете «Эстетического музеума», включавшего в числе прочего и копии произведений античного искусства и архитектуры; однако данный проект осуществлен не был (Петров, 2012. С. 16). Позднее археологические материалы начал собирать известный антиковед К.К. Гёрц, преподававший на кафедре теории изящных искусств и археологии, проводивший раскопки на Тамани и заведовавший университетским археолого-нумизматическим кабинетом (Петров, 2012. С. 17). А в 1888 г. из Кабинета изящных искусств, который находился в ведении кафедры теории изящных искусств и археологии, в Исторический музей были переданы различные археологические (в том числе нумизматические) экспонаты, включая знаменитый Галичский клад (Петров, 2012. С. 28).

И все же начало регулярного преподавания археологии в Московском университете связано не столько с вышеупомянутой кафедрой, сколько с именем профессора Д.Н. Анучина, знаменитого российского археолога, этнографа, антрополога и географа, окончившего в 1867 г. естественное отделение физико-математического факультета Московского университета. Начиная с 1880 г. Д.Н. Анучин работал на кафедре антропологии (основанной в 1876 г. по инициативе А.П. Богданова), где читал лекции по археологии, антропологии и этнографии вплоть до закрытия данной кафедры в 1884 г., после чего он был направлен на кафедру географии и этнографии, открытую при историкофилологическом факультете. В 1888 г. эту кафедру переводят на естественное отделение физико-математического факультета, где Д.Н. Анучин продолжал свое преподавание. В 1907 г. кафедра географии объявила специализацию «география и антропология», спецдисциплинами которой были, в том числе, курсы, которые вел Д.Н. Анучин: археология, физическая антропология, общая этнография и сравнительное народоведение.

Именно благодаря Д.Н. Анучину специализация по археологии в Московском университете стала постоянной, но при этом до Октябрьской революции 1917 г. она осуществлялась лишь на кафедре географии и этнографии - то есть там, где работал Д.Н. Анучин. После революции сфера преподавания археологии в Московском университете расширилась. Теперь археологию изучали уже на двух факультетах.

Во-первых, соответствующая подготовка велась на вновь организованной в 1919 г. (во главе с Д.Н. Анучиным) кафедре антропологии естественного отделения физикоматематического факультета МГУ. Помимо Д.Н. Анучина, скончавшегося в 1923 г., здесь работали такие крупные археологи, этнографы и антропологи, как Б.А. Куфтин, В.В. Бунак, Б.С. Жуков. Сотрудники кафедры антропологии, а также Института антропологии МГУ (открытого в 1922 г. при том же физико-математическом факультете как самостоятельное учреждение), принимали активное участие в подготовке археологических кадров, в разработке археологических методик, вели не только антропологические, но и археологические полевые исследования.

Во-вторых, археологию начинают преподавать на факультете общественных наук (ФОН). ФОН был основан в марте 1919 г. и состоял изначально из трех отделений юридико-политического (или правового), экономического и исторического, перенесенного сюда с историко-филологического факультета. В марте 1921 г. в рамках ФОН были утверждены новые отделения (статистическое, внешних сношений, литературнохудожественное), а осенью 1921 г. - археологическое отделение, ставшее прообразом будущей кафедры археологии исторического факультета МГУ. В конце 1923 г. на базе археологического отделения и художественного цикла литературно-художественного отделения было создано отделение археологии и искусствознания. В апреле 1925 г., после преобразования ФОН в два факультета - этнологический и советского права - отделение археологии и искусствознания вошло в состав этнологического факультета под названием «историко-археологическое». Но при всех реорганизациях, которым подвергался ФОН, в его составе и в составе дочерних факультетов продолжало функциониро- 
вать археологическое отделение в МГУ (меняя названия, но не суть) вплоть до своего закрытия в начале 1930-х гг. - периода масштабных гонений на историческую науку.

Преподавание археологии на Археологическом отделении осуществлялось под неизменным руководством выдающегося ученого В.А. Городцова. Он читал целую серию курсов по археологии, вел семинары и специальные занятия по методике полевых археологических исследований. Именно В.А. Городцов впервые выдвинул и реализовал идею регулярных полевых археологических студенческих практик. В.А. Городцов разработал сводную программу курсов археологического отделения факультета общественных наук, и это была первая всеобъемлющая и систематическая программа обучения археологии в Московском университете (см. подробнее: Канторович, 2009. С. 210-211). В составе преподавателей археологического отделения в МГУ были такие видные ученые, как Ю.В. Готье, Ф.В. Баллод, А.А. Захаров, А.С. Башкиров, Н.И. Новосадский, А.И. Некрасов, А.А. Некрасов и др. Курс истории материальной культуры в 1921/1922 учебном году на ФОН читал Д.Н. Анучин.

Выпускниками Археологического отделения стали многие впоследствии знаменитые археологи, в частности А.В. Арциховский, А.Я. Брюсов, Б.Н. Граков, П.А. Дмитриев, С.В. Киселев, Б.А. Рыбаков, А.П. Смирнов и др. И закономерно, что именно А.В. Арциховский - ученик В.А. Городцова - после длительной паузы в преподавании археологии в МГУ начал в 1937 г. чтение общего курса по археологии для студентовтретьекурсников исторического факультета МГУ, а в 1939 г. стал основателем кафедры археологии Московского университета и первым ее заведующим.

\section{ЛИТЕРАТУРА}

Канторович A.P., 2009. Заметки о преподавательской деятельности В.А. Городцова в Московском университете // Хорошие дни. Памяти Александра Степановича Хорошева / Отв. ред. А.Е. Мусин. Великий Новгород - Санкт-Петербург - Москва. С. 309-313.

Петров Ф.A., 2012. Московский университет и Исторический музей // Вестник Московского университета. Серия 8: История. № 2. С. 14-46.

https://doi.org/10.25681/IARAS.2019.978-5-94375-275-9.26-27

Л.Ю. Китова

(Кемерово)

\section{У ИСТОКОВ СОВЕТСКОЙ АРХЕОЛОГИИ В СИБИРИ}

До революции в Сибири главными центрами по исследованию археологических памятников, изучению и сохранению археологических артефактов были музеи и отделы Императорского Русского географического общества. Первый в Сибири университет (Первый Сибирский Томский Императорский имени Александра III) был основан в 1888 г. в Томске и первоначально имел только один - медицинский - факультет. В 1898 г. в нем были учреждены юридический и физико-математический факультеты. Временное правительство 1 июля 1917 г. открыло историко-филологический факультет университета и естественное отделение физмата, в том числе создав на последнем кафедру географии, студентам которой читались не только профильные дисциплины, но и курсы по этнологии, антропологии и по доисторическому прошлому Сибири. Второй сибирский университет с историко-филологическим и юридическим факультетами был организован под напором иркутской общественности в 1918 г. правительством А.В. Колчака. По его приказу были эвакуированы в Томск и Иркутск профессора и студенты Казанского и Пермского университетов. Началось преподавание в вузах палеоэтнологии, археологии, древней истории, этнографии. Преподаватели вузов (в Томске С.И. Руденко, С.А. Теплоухов, в Иркутске - Б.Э. Петри) вместе со студентами проводили полевые исследования археологических памятников.

После окончания Гражданской войны в Сибири советское правительство очень быстро начало реформировать систему высшего образования в регионе по тем же прави- 
лам, что и в столицах. В 1921 году все гуманитарные факультеты сибирских университетов были объединены в факультеты общественных наук (ФОН). Была, правда, своя особенность существования сибирских университетов: в рядах старой профессуры сразу стали искать пособников А.В. Колчака, поэтому началась активная пролетаризация и профессорско-преподавательского состава, и поступающих в вузы студентов. Средств для поддержания университетов в стране не хватало, но также слишком мало было подготовленных специалистов для промышленности, сельского хозяйства. Перед советским правительством стояли сложные задачи - ликвидировать неграмотность, подготовить кадры с высшим образованием для страны. И государство приняло решение оставить в провинциальных университетах только факультеты, имеющие прикладное значение, а обучение сократить до 3-х лет. Таким образом, уже в 1922 г. закрывают ФОН в ТГУ, недоучившимся студентам предлагают перевестись в Иркутск или Петроград.

Возможность получить высшее историческое образование в Сибири сохранится в Иркутске, но лишь до 1926 г. Организатор подготовки палеоэтнологов на факультете, Б.Э. Петри не просто руководил кафедрой первобытной культуры, но и основал первую сибирскую школу археологов. Он разработал собственную систему подготовки научных кадров. Профессор Петри учредил музей этнографии, кабинет археологии и этнографии коренных народов Сибири, создал студенческий научный кружок. Каждому студенту на лето давалось индивидуальное задание по поиску и исследованию археологических памятников. На собрании студенческого кружка, которое часто проходило вместе с заседанием палеоэтнологической секции Восточно-Сибирского отдела Русского географического общества (ВСОРГО), заслушивались и обсуждались самостоятельные доклады студентов по теме летних изысканий. Для подготовки студентов-археологов Б.Э. Петри написал и опубликовал очерки по палеолиту, неолиту и древней истории Сибири, разработал и издал программу исследования стоянок под открытым небом и др.

Тем не менее, в 1926 г. закрываются и кафедра, и ФОН в Иркутском университете. Выпускники Петри - М.М. Герасимов, Г.Ф. Дебец, Г.П. Сосновский уезжают в аспирантуру столичных научных учреждений. В 1934 г. туда же отправится и А.П. Окладников. В 1930 г. закрывают весь университет, правда, через год его восстанавливают, но уже без гуманитарных факультетов. В отличие от столиц в сибирских университетах историческое образование будет возрождено лишь в 1940 г.

В.А. Городцов в 1920-е годы старался наводнить сибирские музеи своими учениками-археологами. В Омске и Минусинске трудилась В.П. Левашева, в Красноярске и Новосибирске - Н.К. Ауэрбах, в Бийске и Горно-Алтайске - С.М. Сергеев, в Красноярске В.Г. Карцов и А.Ф. Катков. Кто-то из учеников Городцова, как С.В. Киселёв, Л.А. Евтюхова, П.А. Дмитриев, Е.Н. Липеровская, систематически организовывали археологические экспедиции в Сибирь из Москвы.

В 1920-е гг. активно начала развиваться краеведческая археология. Однако благоприятная ситуация для развития науки собственно в Сибири продолжалась недолго. С 1929 по 1937 г. прошла волна репрессий по сибирским музеям. Были арестованы и расстреляны Б.Э. Петри, директор Иркутского музея Н.Я. Ходукин, директор Минусинского музея А.В. Харчевников, директор Томского краевого музея М.Б. Шатилов, директор Бийского музея А.П. Марков, заведующий музеем истории материальной культуры ТГУ А.К. Иванов и многие другие. В 1930 г. умер Н.К. Ауэрбах, в 1932 г. погиб А.Ф. Катков, в 1934 г. уехал в Москву В.Г. Карцов. Из археологов в сибирских музеях остались только В.П. Левашева и С.М. Сергеев, при этом у Варвары Павловны были репрессированы муж и отец, а она выселена с маленькими детьми из квартиры.

В 1931 г. было ликвидировано Общество изучения Сибири (один из руководителей - Н.К. Ауэрбах). В 1930 г. ВСОРГО переименован в краевое Общество по изучению производительных сил Восточной Сибири и переориентирован только на изучение экономики и географии края. Затем в 1937 г. и это Общество было распущено.

Таким образом, уничтожение провинциальных археологических центров подорвало развитие провинциальной науки в Сибири на несколько десятилетий. 


\section{К ИСТОРИИ СОХРАНЕНИЯ ОЛЬВИИ В РЕАЛИЯХ 1914-1930-х ГОДОВ}

Начиная со времени своей «гибели» во второй половине IV в. и до начала XX в., Ольвия имела ряд нерешенных проблем из-за малого внимания к потребностям охраны и сохранения ее исторических ценностей со стороны властных структур государств, на территории которых оказывалась в разные периоды истории. Среди острых проблем одной из важнейших на протяжении многих веков была ее защита от проведения несанкционированных раскопок и хищения античных артефактов. Определенные шаги в направлении решения этой проблемы в начале XX в. проводила Императорская археологическая комиссия, но это не был системный подход. Во время событий 19141920 -х гг., на которые пришлись испытания Первой мировой войной, двумя революциями и Гражданской войной, участились сокрушительные грабительские раскопки местными жителями Ольвии и ее некрополя. Ни один законодательный орган действующих в эти годы политических режимов не приложил усилия к осуществлению мероприятий по охране этого выдающегося памятника античной культуры.

В то время, когда властные структуры бездействовали в решении проблемы охраны и сохранения Ольвии, за дело брались общественные организации. Например, Одесское общество истории и древностей (ООИД) в период 1917-1920 гг. в течение двух лет обращало внимание органов власти на эту проблему. В 1918 г. руководство Общества обратилось в Главное управление по делам искусств и национальной культуры правительства гетмана П. Скоропадского с ходатайством принять решительные меры по пресечению хищений и обеспечения охраны остатков древнего города, но определенные обстоятельства не позволили довести это дело до конца. В следующем году - 15 сентября 1919 г. - председатель Совета ООИД профессор Б.В. Варнеке и секретарь этого же Общества профессор А.В. Флоровский подали ходатайство попечителю Одесского учебного округа о предоставлении «военной стражи» для охраны и сохранения Ольвии. 12 октября 1919 г. Управление Главноначальствующего Новороссийской области сообщило попечителю Одесского учебного округа, который 17 октября 1919 г. в свою очередь сообщил руководству ООИД, что «...ходатайство об охране раскопок места Ольвии в данное время невыполнимо, так как все войска находятся на фронте» (ГАОО. Ф. 42. Оп. 35. Д. 2826. Л. 235-236.). Таким образом, действующие в период 1918-1919 гг. власти не смогли осуществить проведение мероприятий по охране и сохранению материального наследия Ольвии от уничтожения и разграбления.

Трагической судьба Ольвии оставалась и в первые месяцы после установления в январе 1920 г. на Николаевщине советской власти. Местные жители продолжали грабительские раскопки, чему способствовали некомпетентные действия новой власти. Так, Парутинский волостной революционный комитет не останавливал «народные раскопки», а наоборот раздавал крестьянам земельные участки за пределами села в районе склепов и могил, что способствовало активизации ограбления остатков античного города. Первые действия советской власти по охране и сохранению материального наследия Ольвии были проведены в сентябре 1921 г., когда СНК УССР принял постановление о введении соответствующих мер. В 1921 г. полномочия по охране Ольвии были переданы в подчинение Одесского государственного историко-археологического музея. Именно эти постановления дали положительный результат в прекращении беспорядков местного населения относительно материального наследия древнегреческого города, но окончательное решение проблемы его охраны состоялось в 1920-х гг.

В период с 9 декабря 1922 г. по 27 декабря 1923 г. осуществлялась переписка между Одесским губернским отделом политпросвещения и НКО УССР. Следствием этой длительной переписки стал перевод Ольвии из подчинения Одесскому губполитпросу в непосредственное руководство Научного комитета Главного управления профессионального образования НКО УССР (в 1924 г. преобразовано в Украинское главное 
управление научными учреждениями НКО УССР - Укрнауки). Перевод Ольвии в ведомство Укрнауки способствовал быстрому решению проблемы охраны и сохранения ее артефактов. 30 апреля 1926 г. на заседании Президиума Укрнауки было принято решение о выделении средств НКО УССР на ремонт «сигнальной башни» и «археологического дома», разграничение античного города и некрополя от крестьянских земель. Эпохальное постановление в решении проблемы охраны и сохранения Ольвии произошло 11 сентября 1926 г., когда на заседании Президиума Укрнауки был принят проект положения о предоставлении Ольвии статуса государственного заповедника (ЦГАВОВУ. Ф. 166. Оп. 5. Спр. 731. Л. 82). Учредительный документ заповедника, который должен был регулировать его правовое положение, полномочия и порядок деятельности, отношения, связанные с внутренним управлением, отношения с другими организациями или гражданами разрабатывали более трех лет. Он был официально опубликован 2 января 1930 г. (Статут..., 1930. С. 6-7.). Проведенные Укрнаукой в середине 1920-х гг. мероприятия способствовали налаживанию и формированию системы охраны и сохранению Ольвии.

В 1938 г., с подчинением заповедника Ольвия Институту археологии АН УССР проведение ежегодных археологических экспедиций и стабильное финансирование для улучшения условий исследования, охраны и сохранения артефактов древнегреческого города прекратилось. Эти действия привели к тому, что на период 1938-1941 гг. приходится перерыв в проведении археологических исследований в Ольвии. Еще более непоправимый вред исследованию, охране и сохранению Ольвии и ее некрополя нанесли события Второй мировой войны, когда немецко-румынские оккупанты грабили и в большинстве бесследно вывозили артефакты античного города. Таким образом, за весь период первой половины XX в. именно действия советской власти на протяжении 1920-х - 1930-х гг. дали положительный результат в налаживании вопросов исследования, охраны и сохранения Ольвии.

\section{ЛИТЕРАТУРА}

Статут..., 1930. Статут про державний заповідник «Ольбія» // Бюлетень Народного комісаріату освіти УСРР. № 2.

https://doi.org/10.25681/IARAS.2019.978-5-94375-275-9.29-31

О.М. Мельникова

(Ижевск)

\section{АРХЕОЛОГИЯ НА ТЕРРИТОРИИ УДМУРТИИ В 1920 - НАЧАЛЕ 1930-х ГОДОВ: ОТ НАУЧНЫХ ОБЩЕСТВ К НАУЧНЫМ УЧРЕЖДЕНИЯМ}

Становление советской археологии, в особенности на начальных этапах, имело немало специфических региональных черт, предопределенных особенностями научного и образовательного ландшафта, сложившегося в регионах России к моменту революций, глубиной административно-территориальных преобразований, зачастую разрывавших сложившиеся исследовательские коммуникации. Для национально-государственных образований, каковым в 1920 г. стала Вотская автономная область (ВАО), немаловажным фактором была и степень их вхождения в эпоху модерна.

Своего значительного развития в дореволюционные годы местная археология как часть родиноведческих практик достигла в исторической журналистике, а наивысшего расцвета - в такой форме самоорганизации местных сообществ как научные общества. Первым опытом такого рода на территории Удмуртии стал музей Сарапульского земства (1909) и Общество изучения Прикамского края (1913). Эпоха Великих реформ способствовала эмансипации личности и постепенному размыванию сословной стратификации, а вслед за ней и сословной идентичности. Поиск новой коллективной идентичности для городского сообщества, включавшего дворян, духовенство, купечество, представителей разночинной среды, привел к осознанию ими общности локальной. Развитие самоуправления через осознание общности местных проблем закономерно формирова- 
ло локальную идентичность. Очевидно, это понимание нуждалось и в глубоком историческом подкреплении. Не случайно именно в пореформенные годы в разных губерниях возникали научные общества, взявшие на себя миссию формирования и поддержания локальной идентичности через изучение истории уездов, в том числе в археологическом отношении.

Советское административное реформирование разделило прежний Сарапульский уезд между Уральской областью и ВАО. Для последней создание научных учреждений, в том числе связанных с развитием археологии, сдерживалось тем, что его столицей стал поселок Ижевского завода, получивший по этому случаю статус города. До этого он был крупнейшим селом во всей России, численно превосходя не только уездный Сарапул, но и губернскую Вятку. Обретение столичности и выполнение «центральных» функций, в том числе в деле развития археологических исследований, было связано с созданием соответствующих местных органов власти. В ВАО, как и в других регионах РСФСР, в 1923 г. был создан Академцентр, а координация научной работы осуществлялась облисполкомом, отделом народного образования, постоянной комиссией по экспедициям. Их встраивание в систему органов государственной власти предопределило контакты с Наркомпросом РСФСР, в особенности с ГУСом, Главнаукой и Главмузеем. При этом ГАИМК как одно из новых советских учреждений, реже, но мелькнет в коммуникациях местных органов власти.

Развитие науки в целом и археологии в частности в регионе сдерживалось отсутствием кадров: 80\% населения ВАО было неграмотным. Поэтому в начале 1920-х гг. немало инициатив, связанных с изучением археологии, исходило из Казани (ОАИЭ, Союз мелких народностей Поволжья, Северо-Восточный археологический и этнографический институт), где еще до революции небольшая часть удмуртов получала образование (Загребин, 2004. С.101-106; Мельникова, 2018. С. 294-300). Губернская Вятка так же сохраняла интеллектуальные связи с уездами, отошедшими в состав ВАО (пединститут и Научно-исследовательский институт краеведения при нем). Значительная часть предложений, в том числе археологического характера, принадлежала студентам-удмуртам, обучавшимся в Москве.

Воспроизведение у себя «столичной» модели жизни привело к созданию в социокультурном пространстве Ижевска новых институций: музея местного края и Научного общества изучения Вотского края (НОИВК). Городские обыватели, уже приобщившиеся к модерным формам жизни, составили интеллектуальную основу этих организаций. Это были солдаты, прошедшие через мировую войну, немногочисленный слой образованных людей, получивших образование и первичную научную социализацию в Казани, принявшие революцию краеведы, имевшие опыт археологической деятельности, студенты-удмурты, обучавшиеся в Москве. Они ставили перед органами власти вопросы, связанные с организацией археологических экспедиций, сохранением, экспонированием коллекций в музее местного края, инициировали публикацию материалов в «Трудах» Общества, поддерживали личные контакты со столичными археологами. Однако, как показывают вновь выявленные источники, создание самого Научного общества было инициировано ГУСом НК РСФСР: еще не вставший на ноги местный Академцентр в 1924 г. был расформирован и на его месте в 1925 г. было образовано НОИВК (ЦГА УР. Р-195. Оп.1. Д. 159. Л. 94).

Этнизация региональной истории, направленная на конструирование этнического самосознания, предопределила содержательную специфику и направление археологических исследований на все десятилетие 1920-х гг. Эти задачи потребовали привлечения профессионалов из Москвы: Удмуртская экспедиция ГАИМК, ГИМа, РАНИОН 1926 года и ряда последующих лет во главе с С.Г. Матвеевым и А.П. Смирновым, финансируемая ВАО при организационной поддержке НОИВК, фактически выполнила миссию культурного трансфера. Коллекции, полученные в результате археологических изысканий, выставленные в музее местного края, научные публикации по их осмыслению, имели большое значение для развития научной культуры в ВАО (об этом ярко свидетельствует переписка ученых с местными деятелями). Удмуртские археологические ма- 
териалы, соединенные с данными этнографии, получали историческую интерпретацию, вписывая их (и народ) в широкий национальный, европейский и всемирноисторический контекст, повышая статус региона (и народа) в собственных глазах.

С.Г. Матвеев, подводя итоги первого года работ в ВАО, указывал: «ВАО настолько богата археологическими памятниками, древнейшие материальные культуры, бытовавшие на ее территории настолько мало исследованы, что предстоит еще большая работа» (ЦГА УР. Ф. Р-195. ОП. 1. Д. 498. Л. 85).

Из всех направлений работы НОИВК деятельность в области археологии была наиболее успешной, но она осуществлялась на добровольной основе, что не могло не сказаться на ее систематическом характере. На это обращали внимание ГУСа, инициатора создания научного краеведческого общества, руководители ВАО: «Организации особого научного общества следует считать нежизненными, так как частное научное общество, являясь любительской, а не государственной организацией, не сможет вести самостоятельную систематическую работу, требующую лучших местных сил и значительных материальных ресурсов» (ЦГА УР. Ф. Р-195. Оп. 1. Д. 159. Л. 95).

В 1931 г. ресурсы, имевшиеся в ВАО, были вложены в создание Удмуртского научно-исследовательского и Удмуртского государственного педагогического институтов, которые могли бы преодолеть эти проблемы. Но политические процессы начала 1930-х гг., обвинения в национализме активных деятелей 1920-х гг. изменили направление региональной археологической тематики: произошел вынужденный отказ от этнически окрашенной истории, основанной на комплексных археолого-этнографических исследованиях. Наметившийся классовый подход к изучению региональной истории ярко выразился в критике работы музея местного края на страницах журнала «Советский музей». Именно там экспонировались материалы археологических экспедиций 1920-х гг. и для пополнения его фондов предпринимались археологические экспедиции: «Как ни странно, но посетитель Ижевского музея почти ничего не знает о промышленности республики. И одновременно будет прекрасно информирован об экономике древних времен по материалам могильника “Чем-Шай”» (Ильинский, 1936. С. 5).

\section{ЛИТЕРАТУРА}

Загребин A.E., 2004. Казань, финно-угорская этнография и институт местных помощников // 125 лет Обществу археологии, истории и этнографии при Казанском университете. Проблемы историко-культурного развития Волго-Уральского региона. Казань: Казанский государственный университет. Ч. 3. С. 101-106.

Ильинский B.A., 1936. По музеям периферии (Из блокнота краеведа) // Советский музей. № 3. С. 48-51.

Мельникова O.M., 2018. Северо-Восточный археологический и этнографический институт в Казани: на переломе исторических эпох (1917-1921 гг.) // Памятники археологии в исследованиях и фотографиях (памяти Галины Вацлавны Длужневской). СПб.: ИИМК РАН. С. 294-300.

\section{УЧЕНОЕ СОВЕЩАНИЕ ПРИ КРЫМОХРИСЕ: СТАНОВЛЕНИЕ НАУЧНОГО ПАМЯТНИКОВЕДЕНИЯ В РЕГИОНЕ (1920-1921)}

Сложный переходный период от досоветских форм работы по организации изучения и охраны культурного наследия в Крыму к новым, уже устоявшимся на материковой части России формам учреждений подобного профиля, пришелся на 1920-1921 год. На полуострове уже сложилась практика археологических исследований и охранных работ, которые проводились при непосредственном участии Императорской археологической комиссии (Непомнящий, 2018). 
В Рукописном отделе Научного архива Института истории материальной культуры сохранился содержательный документ, отражающий историю научной жизни Крыма в данную эпоху. Это письмо первого заведующего КрымОХРИСа (Крымского областного комитета по делам музеев и охране памятников старины, искусства и природы) Г.А. Бонч-Осмоловского в Российскую академию истории материальной культуры, датированное 23 июля 1921 года. Из него явствует, что в ноябре 1920 г. в Симферополе при ОХРИС было образовано специальное Ученое совещание. В его состав, кроме самого Бонч-Осмоловского, вошли представители Таврического университета - профессора-историки А.Н. Деревицкий, Д.В. Айналов, А.И. Маркевич (он также представлял и Таврическую ученую архивную комиссию), Н.Л. Эрнст; представители естественных наук - профессора М.М. Завадовский, Н.И. Кузнецов, В.И. Лучицкий, С.П. Попов; представитель Крымского общества естествоиспытателей и любителей природы профессор Н.Н. Клепинин. С учетом обилия крымско-татарских культурных объектов были привлечены исследователи этой группы памятников - У.А. Боданинский, А.А. Абиев и О.А. Акчокраклы; заведующий художественным сектором Я.А. Тугендхольд. Руководитель ОХРИСа просил столичных коллег способствовать укреплению положения Ученого совещания и ставил вопрос об объединении крымского Ученого совещания с Российской академией наук (РО НА ИИМК. Ф. 2 - 1921 г. Д. 71. Л. 12).

Разработанный документ «Об Ученом совещании при Крымском областном комитете по делам музеев и охране памятников старины, искусства и природы» включает следующие задачи Совещания (РО НА ИИМК. Ф. 2. Оп. 1 - 1922 г. Д. 57. Л. 7-7 об.):

«§1. Ученое совещание объединяет всю научную деятельность по охране памятников старины и культурных ценностей. На его обязанности лежит забота о выполнении всех требований археологии при раскопках и изысканиях, о строго научной и художественной реставрации памятников старины, принятии мер к предохранению достопримечательностей природы, имеющих историческое, археологическое или эстетическое значение, от порчи и уничтожения, выполнение задач, требующих особых знаний и доступных лишь специалистам.

$\S 2$. Для этой цели совещание выделяет отделения археолого-этнографическое, естественно-историческое и др. по мере надобности, созывает заседания пленарные и по отделениям и выделяет комиссии.

§3. Ученому совещанию принадлежит научное руководство всеми учреждениями, занятых охраной, сбором и распределением памятников старины, искусства и природы. На его обязанности лежит следить за тем, чтобы во всех мероприятиях этих учреждений соблюдались все требования современной науки.

$\S 4$. Совещание разрабатывает и утверждает планы и программы всех работ по охране памятников старины искусства и природы.

§5. Совещание сносится непосредственно с Академией Истории Материальной Культуры в Петрограде по вопросам своего ведения».

31 июня 1921 года Бонч-Осмоловский информировал Совет Академии истории материальной культуры о произошедшем в январе 1921 года слиянии Ученого совещания КрымОХРИСа с образованной в Севастополе Археологической комиссией, организаторами которой стали известные крымские археологи К.Э. Гриневич (1891-1970) и Л.А. Моисеев (1882-1946). Ученое совещание с этого времени разделилось на две комиссии: этнолого-археологическую и естественно-историческую. Г.А. БончОсмоловский так определял цели Ученого совещания: «Разрешение всех научных вопросов, связанных с делом охраны и музееведения, научные исследования и изыскания в области крымоведения, в частности по археологии и этнографии Крыма, издание статей и планов» (РО НА ИИМК. Ф. 2. Оп. 1 - 1921 г. Д. 71. Л. 13-13 об.).

На заседаниях Ученого совещания предварительно обсуждались все наиболее важные вопросы деятельности КрымОХРИСа. За первый год работы Ученое совещание провело 26 заседаний. На них читались и обсуждались доклады и разрешались многочисленные вопросы, связанные с постановкой музейного дела, с охраной памятников старины в Крыму, с защитой памятников природы и с распространением знаний о Крыме, его древностях, богатствах и природе. 
В конце лета 1921 года Ученым совещанием был созван Съезд представителей уездных ОХРИСов, на котором установлена связь с местами и разрешались основные и наиболее наболевшие вопросы, входящие в компетенцию ОХРИСов. Помимо организационных вопросов доклады, читавшиеся на заседаниях Съезда, посвящались и научным проблемам из области археологии. Наиболее важными докладами, заслушанными и обсуждавшимися на заседаниях Ученого совещания стали следующие:

- Н.И. Кузнецов «Организация общеобразовательных экскурсий в Крыму»;

- Н.Н. Клепинин «Об охране памятников старины и природы в Крыму»;

- Д.В. Айналов «Таблицы по искусству доисторического человека»;

- Н.Л. Эрнст «Неолитическая стоянка у села Саблы Симферопольского уезда (отчет о разведке)»;

- И.Н. Лаговский «Очерк истории фарфора в Европе (как введение к коллекции фарфора Центрального музея Тавриды)»;

- $\quad$ П.Я. Чепурина «Старинные деревянные татарские дома в Евпатории и их охрана»;

- П.И. Новицкий «Охрана татарской старины и искусства»;

- П.И. Крестианполь «Устройство при музеях художественных выставок и др.»

Участники Ученого совещания непосредственно занимались учреждением в Симферополе Центрального музея Тавриды, выбором для него здания, перевозкой туда музея Таврической ученой архивной комиссии, организацией экспозиции. Благодаря их участию прошло учреждение художественных музеев в Ялте, Севастополе, Феодосии, Евпатории, Керчи, Судаке, Алуште и Гурзуфе. Объявлены музеями дворцы: Ливадийский, дворцы графов Воронцовых в Алупке, князей Долгоруких в Мисхоре, князей Юсуповых в Кореизе, графини Паниной в Гаспре, великого князя Александра Михайловича в Ай-Тодоре, великого князя Петра Николаевича в Дюльбере, князя Юсупова в Коккозе; князя Голицына в Новом Свете, Пушкинского домика в Гурзуфе. Благодаря ходатайству подвижников памятникоохранного дела был «исходатайствован от Крымревкома приказ, запрещающий самовольные раскопки». Начаты мероприятия по охране старинных татарских домов в Евпатории. Производились зарисовка, фотографирование и обмеры старинных построек и памятников Симферополя для образования отдела «Старый Симферополь» в Центральном музее Тавриды. Была взята под охрану Евпаторийская караимская национальная библиотека и другие ценные собрания. (РО НА ИИМК. Ф. 2. Оп. 1 - 1922 г. Д. 57. Л. 5-6 об.). Итогом деятельности Ученого совещания стала «Записка о необходимости учреждения в Крыму Отделения Академии истории материальной культуры» (РО НА ИИМК. Ф. 2. Оп. 1 - 1922 г. Д. 57. Л. 4-4 об.).

\section{ЛИТЕРАТУРА}

Непомнящий А. А., 2018. Арсений Иванович Маркевич // ВИ. № 11. С. 29-48.

https://doi.org/10.25681/IARAS.2019.978-5-94375-275-9.33-35

С.В. Палиенко

(Киев)

\section{ВОПРОСЫ ОРГАНИЗАЦИИ СОВЕТСКОЙ АРХЕОЛОГИЧЕСКОЙ НАУКИ 1920-Х - НАЧАЛА 1930-Х ГОДОВ В ТВОРЧЕСТВЕ СОВЕТСКИХ АРХЕОЛОГОВ-ТЕОРЕТИКОВ ПОСЛЕДНЕЙ ТРЕТИ ХХ ВЕКА}

На постсоветском пространстве история археологии сформировалась в качестве самостоятельной субдисциплины, но до сих пор ведутся дискуссии относительно ее места в общей структуре науки, роли и основных задачах. Пролить свет на эти проблемы поможет изучение процесса становления самой субдисциплины.

В СССР в 1970-е - начале 1990-х гг. развивалась советская теоретическая археология, представители которой также обращались к истории отечественной археологии. Одной из актуальных историографических тем того периода можно назвать теоретиче- 
ские дискуссии конца 1920-х - первой половине 1930-х годов. Проблема организации советской археологической науки в 1920-е гг. касается данной темы опосредовано, однако является очень важной, так как позволяет проследить исторический контекст и предпосылки возникновения дискуссий. Ниже будет рассмотрено, как в историографических работах советских археологов-теоретиков, посвященных археологии межвоенного периода, затрагиваются вопросы институциональной истории 1920-х гг. Это позволит проследить процесс перехода от историографии к истории археологии (в концепции И.Л. Тихонова).

Так, в 1977 г. на заседании методического семинара ЛОИА АН СССР В.М. Массон сделал доклад на тему «У истоков теоретической мысли советской археологии», который в 1980 году был опубликован в виде одноименной статьи в КСИА. Рассматривая период второй половины 1920-х - начала 1930-х годов, автор сделал основной акцент на новых методологических подходах и новой проблематике, с упором на начало 1930-х годов. В статье В.М. Массон также упоминает и об изменениях в структуре ГАИМК в 1934 году.

В 1982 г. вышла первая специализированная монография В.Ф. Генинга «Очерки по истории советской археологии». Главной задачей ее автор определил передачу обстановки рассматриваемой эпохи, характера столкновений в теоретической сфере, отметив, что для этого необходимо показать общее состояние археологической науки, организационную структуру главных археологических учреждений, чему он и посвятил первый раздел.

В.Ф. Генинг выделил первый период в развитии советской археологии (октябрь 1917 г. - середина 1930-х гг.), состоящий из 2 этапов: с октября 1917 по 1929 г. и с начала по середину 1930-х гг. Первый этап он связал с формированием советской археологии на новых организационных началах и сбором основных научных сил.

Что касается непосредственно советской археологии 1920-х гг., то В.Ф. Генинг отметил, что на этом этапе восстанавливается все то ценное в научном наследии, что накопила дореволюционная русская археология, и наряду с этим уже предпринимаются попытки постановки новых задач. По мнению автора монографии, большинство археологов ГАИМК вели исследования в традиционно вещеведческом стиле, чрезвычайно слабо представляя себе задачи новой археологии как исторической науки, основанной на марксизме.

В том же 1982 выходит англоязычная статья Л.С. Клейна с соавторами - В.А. Булкиным и Г.С. Лебедевым - «Attainments and Problems of Soviet Archaeology», которая позже легла в основу его книги «Феномен советской археологии» (издание 1993 г.). В этих публикациях рассматривалось развитие археологической мысли и в межвоенный период с акцентом на теоретические дискуссии. Вопросы институциональной истории в статье и книге затронуты не были.

В январе 1983 года на методсеминаре ЛОИА АН СССР обсуждался доклад М.В. Аниковича «О месте археологии в системе общественных наук (по русской и советской археологической литературе)». Позже исследователь опубликовал цикл статей по этой проблеме. Одной из них является «Проблема определения археологии как науки в советской археологической литературе тридцатых - шестидесятых годов» 1990 года. И хоть М.В. Аникович основной задачей статьи определил изучение внедрения марксизма в методологическую проблематику самоопределения археологии как науки, для чего необходима и оценка ситуации в стране в тот период в целом, однако вопросы институциональной истории в публикации затронуты не были.

В 1991 году выходит монография Г.С. Лебедева «История отечественной археологии: 1700-1917 гг.», где в «Заключении» была затронута и рассматриваемая проблема. По мнению автора книги, главной задачей в сфере культурного строительства начала 1920-х годов было восстановление и развитие основных элементов социокультурной структуры, в частности, организационная работа в области археологии и родственных гуманитарных наук составила основное содержание начального этапа деятельности ГАИМК (1919-1929). Ученый указал, что перегруппировка интеллектуальных сил, 
унаследованных от царской России, достигала главной задачи: лучшие кадры отечественной науки, сохранившиеся и подготовленные на базе дореволюционного культурного фонда, принадлежали прежней российской культуре.

Таким образом, к истории советской археологии 1920-х - 1930-х годов обращались представители практически всех направлений советской теоретической археологии 1970-х - начала 1990-х. Этой теме посвящены доклады на методсеминарах, статьи и монографии. Вопросы институциональной истории 1920-х годов были затронуты только в книгах В.Ф. Генинга (1982) и Г.С. Лебедева (1991) - то есть прослеживается зависимость не от времени выхода публикаций, а от их формы. И, если в статьях данный вопрос не поднимался в виду ограниченности объема, то в монографии Л.С. Клейна (1993) это, по-видимому, связано с рассмотрением только общих тенденций развития археологической мысли.

Оба указанных автора представляли разные направления теоретической археологии и стояли на противоположных мировоззренческих позициях. Поэтому интересным является то, как ими подавался факт, что в 1920-е гг. основу сотрудников ведущих институций составляли представители дореволюционной археологии. Г.С. Лебедев делает акцент на передаче традиций предшествующего периода, основанных на российской культуре, а В.Ф. Генинг обращает внимание на неспособность перехода представителей дореволюционной археологии к новой методологии. Это, по нашему мнению, является хорошим примером влияния мировоззрения ученого на результаты их научной деятельности.

\section{ЛИТЕРАТУРА}

Генинг В.Ф., 1982. Очерки по истории советской археологии : У истоков формирования марксистских теорет. основ сов. археологии, 20-е - первая половина 30-х гг. Киев: Наукова думка. 225 с.

Клейн Л.С., 1993. Феномен советской археологии. СПб: Фарн. 128 с.

Лебедев Г.С., 1992. История отечественной археологии: 1700-1917 гг. СПб.: Изд-во СПб ГУ. $461 \mathrm{c.}$

Массон В.М., 1980. Отдел полевых исследований Института археологии АН СССР // КСИА. Вып. 163. С. 18-26.

https://doi.org/10.25681/IARAS.2019.978-5-94375-275-9.35-36

Е.Г. Панкратова

(Санкт-Петербург)

\section{АРХЕОЛОГИЧЕСКИЕ ЭКСПЕДИЦИИ 1930-Х ГОДОВ НА ТЕРРИТОРИИ ГУЛАГа (ПО МАТЕРИАЛАМ САНКТ-ПЕТЕРБУРГСКОГО ФИЛИАЛА АРХИВА РАН)}

История археологических раскопок на территории строек крупнейших промышленных объектов в 1930-х гг. тесно связана с историей формирования системы исправительно-трудовых лагерей (ГУЛАГ) и организацией использования принудительного труда заключенных, которое рядом Постановлений СНК и Политбюро ВКПб было закреплено на государственном уровне. Законодательные основания под систему ГУЛАГ были подведены в 1933 г., после утверждения исправительно-трудового Кодекса РСФСР, который прописывал различные аспекты функционирования лагерей. К тому времени сеть ГУЛАГа уже охватывала северные, среднеазиатские и дальневосточные районы страны, что обусловило локализацию на месте лагерных строек археологических памятников разных эпох и культур, от палеолита до средних веков, требовавших обязательного изучения перед началом строительных работ.

До сих пор в истории отечественной археологии изучение специфики взаимодействия системы ГУЛАГ и научных учреждений не выделялось в рамках отдельного исследования. Известно, что в середине 1930-х гг. между ГУЛАГом и Государственной академией историей материальной культуры (ГАИМК) был заключен договор на пред- 
мет проведения охранных археологических раскопок на территории крупных лагерных строек. Организационные вопросы осуществлялись заместителем Председателя ГАИМК Ф.В. Кипарисовым (1929-1936) и секретарем Комитета по проведению работ на новостройках Б.А. Латыниным. Научные сотрудники ГАИМК принимали участие в археологических раскопках на территории Карагандинского исправительно-трудового лагеря (ИТЛ) (Смирнов, 2019), а также при строительстве Волго-Донского, БеломорскоБалтийского каналов и Байкало-Амурской магистрали. Среди архивных документов Санкт-Петербургского филиала Архива $\mathrm{PAH}^{1}$ содержатся материалы об археологических исследованиях, проводимых в 1933 г. на территории Карагандинского ИТЛ и о разведках, осуществляемых при строительстве Байкало-Амурской магистрали в 19291936 гг. (СПбФ АРАН. Ф. 4. ОП. 28. Д. 6, 9, 13, 19, 27, 60).

Документы, касающиеся раскопок П.С. Рыкова на территории Карлага, немногочисленны. Они состоят из заметки «Научная археологическая экспедиция», опубликованной в местной газете Карлага «Путевка»; Докладной записки П.С. Рыкова на имя начальника лагеря М.М. Чунтонова ${ }^{2}$ с кратким отчетом о произведенных с 13 по 29 июня археологических исследованиях (СПбФ АРАН. Ф. 4. Оп. 28. Д. 19. Л. 49-53), а также приказа по Карлагу от 17 июля 1933 г., выпущенного на основе заключения археологической экспедиции «О памятниках древних эпох на территории лагеря».

Документы о проведении исследований на отдельных участках Байкало-Амурской магистрали представлены: перепиской руководства Геологического института АН СССР с Горным отделом ГУЛАГа и Секретной частью АН СССР за 1934-1937 гг. (СПбФ АРАН. Ф. 4. Оп. 28. Д. 6, 9, 13, 27). Изучение этих материалов позволяет понять процесс подготовки и проведения исследовательских работ, а так же камеральной обработки полученных материалов. Учитывая то, что все работы, проводимые вдоль трассы БАМ, были засекречены, для формирования научного состава экспедиции характеристики всех исследователей утверждались ОГПУ, как и дальнейший допуск к подготовке отчетов и написанию статей.

Очевидно, что все экспедиции, проводимые на территории ИТЛ строго контролировались ГУЛАГом, однако последовательность оформления документации во многом зависела от уровня секретности и стратегической значимости объекта, на территории которого предполагалось проводить исследовательские работы. Безусловно, это лишь самые предварительные выводы. Анализ всего комплекса архивных документов по выделенной тематике позволит получить новые данные, касающиеся регламентирования ГУЛАГом работ археологических экспедиций; решения организационных вопросов между начальством лагерей и руководителями экспедиций; определению дальнейших задач по консервации и изучению открытых археологических объектов. Кроме того, крайне важно проследить, оказывало ли какое-либо влияние на дальнейшую научную карьеру исследователей участие в раскопках на территории таких закрытых объектов, как ИТЛ.

\section{ЛИТЕРАТУРА}

Смирнов Н.Ю., 2019. «Неизвестный контекст знаменитого открытия: экспедиция профессора П.С. Рыкова в Центральный Казахстан в 1933 году (к 85-летию открытия первого памятника бегазы-дандыбаевской культуры)»// Археология Казахстана. № 1 (в печати).

Это единицы хранения Спецотдела по АН СССР, которые хранились ранее в Архиве Октябрьской революции (в настоящее время - Центральный государственный архив) и после их рассекречивания в 1997 г., были переданы в СПбФ АРАН и включены в состав фонда № 4, описи 27, 28, 29 и 30. Д. 6, 9, 13, 19, 27, 60.

2 Чунтонов Михаил Митрофанович (1896-?) - в ВЧК с 1920. Начальник Сибирского управления лагерей ОГПУ (1929-1931), начальник отдела спецпоселений по Казхстану (1931-1932), начальник Карагандинского ИТЛ (1932-1933), начальник Байкало-Амурского ИТЛ (1933-1934), начальник БеломорскоБалтийского ИТЛ (1936-1937). В 1937 г. снят с должности за должностные преступления; в 1939 г. - apeстован. Дата и место смерти неизвестны. 


\section{АРХЕОЛОГИЯ В СССР 1920-х ГОДОВ: ПОПЫТКА СОЦИОБИОЛОГИЧЕСКОГО ПОДХОДА К ИЗУЧЕНИЮ КУЛЬТУРЫ}

После окончательной победы большевиков перед археологами встала насущная задача: во что бы то ни стало найти своей науке место в изменившемся мире. Между тем, история, как таковая, оказалась nongrata в СССР 1920-х гг. Новый режим позиционировал себя как секулярный и атеистический. В этих условиях было важно отмежевать археологию, со всеми ее проблемами, от исторической науки и идеализма в любой форме. Напротив, связь с естествознанием, в любом аспекте, рассматривалась как заведомо выигрышная. Актуальность естественных наук казалась вне сомнений, при любом режиме. Не менее актуальной представлялась этнология, имевшая прямой выход на животрепещущие этнополитические и демографические проблемы.

Акцентирование связи археологии с комплексом естественных наук и этнологией сразу выдвинуло на передовые позиции палеоэтнологическую школу. Изучение культурного процесса в контексте эволюции природной среды и биологической природы Homosapiens рисовалось той наукой завтрашнего дня, к которой следует стремиться.

Научные результаты не заставили себя ждать. В рамках новой платформы в СССР произошла институализация изучения древних технологий, причем не в рамках прикладных, реставрационных работ, а именно как самостоятельного научноисследовательского направления. После 1924 г. началось реальное развертывание в СССР технологических исследований археологических материалов. Принципы, на которых эта работа строилась, являлись, на тот момент, пионерными в общеевропейском масштабе.

Тогда же была уточнена и унифицирована методика раскопок поселений различных эпох. Наряду с широким спектром естественнонаучной аналитики артефактов и их контекстов, начали разрабатываться изощренные приемы обработки и интерпретации собранных коллекций, в том числе корреляционная статистика.

Для археологов представление амбициозных проектов и демонстрация первых полученных результатов имели важную цель: заинтересовать государство новыми перспективами. Но сама советская власть, терзаемая внутрипартийной борьбой, еще не вполне определилась в своих запросах. Археологи, стремясь к деловому сотрудничеству, выдвигали предложения, исходя из собственных представлений о точках пересечения интересов науки и власти. Желая вписать свои исследовательские планы в государственный план, они иногда прибегали к «советской» политической фразеологии, но в целом научный язык сохранял академичность.

Стремление поместить социальное и биологическое в единый исследовательский контекст было характерно для специалистов самых различных школ - для палеоэтнологов, комбинационистов, а также для В.А. Городцова, который причислял археологию к биологическим наукам, а себя самого позиционировал как ученого-естественника. В создавшихся условиях происходил отчетливый дрейф теоретических установок археологии в сторону физикализма. Этот последний подразумевал создание некоего универсального - позитивистского по своей сути - научного знания, базирующегося на естественнонаучной основе, но дающего ключ к проблемам истории, археологии, истории культуры и пр. Великие открытия в биологии в 1-й четверти XX в. позволили говорить о физиологических основах психики человека, о теории рефлексов, как основе научного понимания мышления, о физико-химической природе наследственного вещества... Все это рождало надежду, что вот-вот будет найдено естественнонаучное объяснение многих процессов и явлений социальной жизни.

В том же русле данная проблема ставилась марксистской философией начала XX в. К. Каутский, который вплоть до начала 1930-х гг. считался в СССР одним из самых авторитетных истолкователей марксизма, первым заговорил о «социальных инстинктах» 
и о том, что «нравственный закон» есть, собственно, род «животного инстинкта» (Каутский, 1906: 51, 61-62). По его мнению, область материалистического понимания истории вступала в соприкосновение с областью биологии, а всякое изменение как обществ, так и видов, может быть сведено к изменениям в окружающей среде. Пожалуй, все «биологизаторство», в котором потом обвиняли российских палеоэтнологов, заключалось в следовании этой парадигме.

Однако стремление к познанию неких объективных «законов», уходящих корнями в область взаимодействия биологического и социального, стало для «антропологической археологии» роковым. В конце 1920-х гг., с началом «раскулачивания», резко изменился социально-политический контекст этнологоархеологических исследований. Ранее задачей комплексных антропологических экспедиций было дать объективную сводку о прошлом и настоящем регионов СССР - в том числе и о фактах ухудшения экономического состояния населения. Теперь эта задача отпала: огромный пласт информации о современной жизни СССР разом перешел в режим закрытого доступа. Попытки независимого анализа причин и особенностей культурных изменений, передвижек населения, взаимодействия старого и нового в быту и т.д. - стали попросту невозможны. Это лишало всякого смысла недавнюю установку палеоэтнологов на изучение закономерностей развития культуры путем наблюдения и обобщения данных живых культур. Всякий поиск социобиологических корней поведения человека и человеческих сообществ стал ассоциироваться с расизмом.

Между тем, именно в 1928 г. была сделана интересная попытка ввести в научный обиход понятие «этнографической формации», определяемой как «органическое единство, в котором физический habitus, психологическая структура и материальные, социальные и умственные элементы культуры составляют единое целое» (Кагаров, 1928). Эту «этнографическую формацию» некоторые исследователи именовали «этнической» или «этносом». Но одновременно подчеркивался ее исторический характер и текучесть форм, которые складывались и функционировали в социальном и экологическом контекстах своей эпохи. Таким образом, за «этнографической формацией» можно было видеть не статичное явление, а некий проиесс.

Современные исследователи справедливо отмечают высокую актуальность такой постановки проблемы. Здесь просматривается идейная параллель с концепцией «психоментального комплекса» С.М. Широкогорова, где главную роль играла «идея физической и ментальной реакции на среду (milieu)» (Shirokogoroff, 1935). С другой стороны, появление термина habitus, которым пользовались биологи и медики, обнаруживает попытку «разглядеть социальный смысл тела» - именно то, что реализовал М. Мосс в середине 1930-х гг. в своей знаменитой работе «Техники тела» (Mauss, 1936; От классиков..., 2014. С. 53-54). Совершенно очевидно, что научная мысль российских ученых развивалась в сходном направлении, причем опережающим темпом. Но когда на Западе вышли из печати упомянутые труды C.M. Широкогорова и М. Мосса, в СССР эта тематика оказалась уже недоступной для научного обсуждения. Ее просто «закрыли», определив, как «биологизаторство».

\section{ЛИТЕРАТУРА}

Кагаров Е.Г., 1928. Пределы этнографии // Этнография. № 1. С. 11-23.

Каутский К., 1906. Этика и материалистическое понимание истории. Опыт исследования. Одесса.

От классиков..., 2014. От классиков к марксизму: совещание этнографов Москвы и Ленинграда (5-11 апреля 1929 г.) / Под ред. Д. В. Арзютова, С. С. Алымова, Д. Дж. Андерсона. СПб.: МАЭ РАН. 511 с. (Серия «Кунсткамера - Архив». Т. VII).

Mauss M., 1936. Les techniques du corps // Journal de Psychologie. XXXII. № 3-4. 15 mars -15 avril.

Shirokogoroff S., 1935. M. Psychomental Complex of the Tungus. L.: K. Paul. 


\section{РЕФОРМЫ Б.Ф. АДЛЕРА В КАЗАНСКОМ ГОРОДСКОМ МУЗЕЕ В 1917-1922 ГОДАХ:} АРХЕОЛОГИЧЕСКИЕ КОЛЛЕКЦИИ - ИННОВАЦИЯ ИЛИ УНИЧТОЖЕНИЕ?

Казанский городской музей имени А.Ф. Лихачёва - первый публичный музей Казанской губернии, открывшийся в 1895 г., в первом десятилетии XX в. обладал крупнейшей и одной из самых значительных коллекций археологических предметов в регионе. Основу ее составляли артефакты памятников Волжской Булгарии и Золотой Орды, которые приобрел казанский коллекционер Андрей Федорович Лихачёв. После его смерти в 1890 г., большая часть собрания была выкуплена у вдовы Раисы Ивановны братом покойного - Иваном Федоровичем Лихачёвым и передана в дар Казани. Руководство музея в лице Попечительского совета, куда в обязательном порядке входили члены семьи Лихачёвых, в своей деятельности руководствовались Уставом, согласно которому коллекция собирателя была неприкосновенной и могла только дополняться новыми приобретениями (Руденко, 2017. С. 117-119). При этом практически все экспонаты были выставлены в залах музея. Такая ситуация в российской музейной практике была типичной. И это касалось не только музеев краеведческого или исторического направлений. То же было характерно и для художественных собраний (Семенова, 2010. С. 319).

Однако, состояние самой археолого-этнографической коллекции Андрея Федоровича в музее его имени, как и попытки улучшения экспозиции были бесплодны. Печально было и состояние самого собрания: многие предметы, прежде всего археологические, лежали неразобранными и неучтенными, а размещенные в экспозиции, описанные в каталоге А.Ф. Лихачёва не имели топографической описи. Местонахождение некоторых из них, установить было сразу невозможно, как и факт их наличия (Руденко, 2018. C. 127-130).

С февраля 1917 г. в музее начались изменения. «Демократизация» коснулась сначала Совета музея, куда были допущены надзирательницы (смотрительницы), а осенью этого же года, с упразднением Городской думы, в ведении которой находился музей, он вообще лишился руководства, и Совет фактически был распущен. До начала 1919 г. музей оставался бесхозным, пока Отделом по делам музеев Наркомпроса директором музея был назначен снискавший известность своей музейной деятельностью профессор Казанского университета Б.Ф. Адлер, знаток географии и музейного дела, причем как российского, так и западноевропейского.

Переехав вместе с семьей в Казань в мае 1911 г. и заняв кафедру, он сразу включился в жизнь университета и казанского общества. Он входит в Совет Общества археологии, истории и этнографии при императорском университете, и во все возможные комиссии, а через три года становится заведующим музеем Общества, начав череду новшеств - от проектов передачи коллекций и до организации выставок (Руденко, 2013. С. 327-328).

Революции 1917 г. Б.Ф. Адлер воспринял как шанс осуществить свои самые смелые мечты. Он писал: «революция все изменила: она вдохнула новый дух в музейное дело, заговорили о плане, о музейном строительстве» (Адлер, 1921. С.40). Сказались и амбиции. В 1920 году он заявлял о себе: «Во главе всего Музея [Казанского. - K.P.] стоит так же специалист музеевед проф. Б.Ф. Адлер, проведший большую часть своей жизни в музеях 3[ападной] Европы, Петрограда и Казани» (Адлер, 1923. С. 29).Этот пафосный и реформаторский дух он перенес в Казанский музей, практически сразу отменив все старые правила: был упразднен Лихачёвский отдел, как структурное ядро музея, образованы отделы, а том числе отдельные археологический (затем историкоархеологический) и этнографический. Появилось понятие о фондах. Директор поставил задачу учета музейных предметов, основываясь не на коллекционном принципе, а по 
тематическому распределению (археология, этнография и т.д.), а внутри его по материалу или памятнику где он был найден.

Эта, казалось бы, здравая идея стала осуществляться по-революционному быстро, но, к сожалению, непрофессионально. В отношении археологической коллекции это объяснялось не столько неопытностью сотрудников, а скорее бездействием и нежеланием вникнуть в эту область музейной деятельности назначенного Б.Ф. Адлером начальника археологического отдела музея - М.Г. Худякова. Б.Ф. Адлер ему явно симпатизировал, считая его лучшим специалистом-археологом и, к тому же, большим общественником и деятельным педагогом, что было действительно так. Но то, что происходило в археологических фондах музея во время «руководства» Михаила Георгиевича иначе как катастрофой назвать нельзя. Тщательно нашитые на картоны и подписанные самим собирателем экспонаты Лихачёвской коллекции (Руденко, 2017. С. 116, 117), особенно мелкие: бусы, керамические прясла, металлические украшения и т.п. были срезаны и сложены вместе без маркировки (они, естественно, стали тут же депаспортизованными) и, более того, стали объединяться с другими коллекциями. Более-менее избежала этой участи коллекция первобытной эпохи, но собрание средневековых артефактов оказалось самым пострадавшим.

Почему это произошло, учитывая музейный опыт самого Б.Ф. Адлера, понять трудно. Идеи реформировать музей у него были глобальными и уходили больше в область теории, чем практики: то создать на базе городского музея Музей восточной культуры, то передать его Северо-Восточному археологическому институту и множество других не менее радикальных. Явно была переоценена и возможность организовать наличными в музее силами научную обработку археологических фондов и изучения коллекций, что особенно заметно было в попытках разделения коллекций на археологические и этнографические.

Значение реформ Б.Ф. Адлера все же нельзя оценивать только негативно. Вопервых, они были не завершены. Во-вторых, сам Б.Ф. Адлер со всеми проектами явно не успевал справляться, учитывая дефицит всего - от материалов для ремонта и до музейного оборудования. Не стоит забывать и требования революционной эпохи к музеям. Новые подходы Б.Ф. Адлера к археологическим фондам дали возможность их систематизировать и начать сверку коллекций, что было важно при массовом поступлении археологических артефактов в последующие годы, но, с другой стороны, нанесли им огромный урон, который восполнить уже никогда не удастся.

\section{ЛИТЕРАТУРА}

Адлер Б.Ф., 1921. Главмузей // Казанский музейный вестник. № 3-6. С. 39-61.

Адлер Б.Ф., 1923. Казанский Губернский Музей в 1920 г. и его очередные задачи // Казанский Губернский музей за 25 лет. Юбилейный сборник статей. Казань: типография Комбината издательства и печати «Восток». С. 29-31.

Руденко К.А., 2013. Б.Ф. Адлер: реконструкция биографии (1911-1917 гг.) // Историк в историческом и историографическом времени: Материалы Международного форума / Отв. ред. Г.П. Мягков, Е.А. Чиглинцев. Казань: Яз. С. 326-328.

Руденко К.А., 2014. История археологического изучения Волжской Булгарии (X начало XIII в.). Казань: ГБУ «Республиканский центр мониторинга качества образования». $768 \mathrm{c.}$

Руденко К.А., 2017. Казанские коллекционеры XIX века (из истории музейного дела Казанского края). Казань: Редакционно-издательский центр «Школа». 172 с.

Руденко K.A., 2018. Коммуникационные формы культуры Татарстана: генезис и эволюция (с древности до ХХ в.): учебное пособие. Казань: Редакционно-издательский центр «Школа». 164 с.

Сменова Н.Ю., 2010. Московские коллекционеры: С.И. Щукин, И.А. Морозов, И.С. Остроухов: Три судьбы, три истории увлечений. М.: Молодая гвардия. 403 с. 


\section{УЧАСТИЕ РАИМК И ГАИМК В РАЗВИТИИ АРХЕОЛОГИЧЕСКИХ ИССЛЕДОВАНИЙ НА КАВМИНВОДАХ И В ТЕРСКОЙ ОБЛАСТИ С НАЧАЛА 1920-х ДО СЕРЕДИНЫ 1930-х ГОДОВ}

Тема организации и проведения археологических исследований в районах Северного Кавказа в 1920-е и по середину 1930-х годов и участия в них структур и сотрудников РАИМК-ГАИМК не является новой и рассматривалась уже исследователями, как в общих контекстах, так и специально (А.А. Миллер, Б.В. Лунин, А.А. Иессен, Е.И. Крупнов, В.И. Марковин, М.Е. Колесникова, Ю.М. Луценко, Л.П. Ермоленко, В.А. Алекшин и др.). Из последних публикаций можно выделить статью Л.П. Ермоленко (Ермоленко, 2017. С. 60-64). Но проблематика не исчерпана. В год столетия создания РАИМК целесообразно обобщить уже известные данные, конкретизировать и дополнить их новыми или малоизвестными фактами, сюжетами, недостаточно осмысленными ракурсами и т.п.

Годы революции и гражданского противостояния вели к большим утратам археологического наследия в стране. Сохранение преобразованной Императорской археологической комиссии в 1917 и 1918 годах, а затем и развертывание на ее базе Российской академии истории материальной культуры, являлось заслугой «старых специалистов» из числа авторитетных ученых, их учеников и любителей древностей, проявивших лояльность к советской власти и нашедших поддержку у разумной части перспективно мыслящих управленцев. В начальный советский период налаживалась новая система образования и науки. При этом явно просматривалась преемственность новых центральных и местных археологических центров, нередко формировавшихся на базе действовавших до революции учреждений и обществ, наследовавших их традиции, направления и объекты исследования (Мерперт, 1995. С. 4-6; Платонова, 2010. С. 215) и др.

Основным ресурсом на местах были деятели в сфере археологического наследия и музейного дела, для многих из которых сохранение и изучение отечественных археологических памятников оказалось более значимым, чем политические катаклизмы и личные лишения. Так, в окружном центре Терской области городе Пятигорске, где с 1901-1902 гг. действовало Кавказское Горное общество (КГО), имевшее свой музей с предметами древности и осуществлявшее археологические исследования, попытки организации и упорядочения исследований и охраны памятников предпринимались и в 1918 г. Участие в этом принимали члены КГО: М.А. Гремяцкий, Я.И. Фролов, Д.М. Павлов. На майском собрании Совета по народному образованию в Пятигорске председателем был избран тогда преподаватель естествознания, а в дальнейшем известный антрополог М.А. Гремяцкий, прославившийся интерпретацией черепной крышки так называемого «подкумского человека», найденной в 1918 г. в городе при земляных работах. Присутствовали на собрании и другие члены КГО. Его участниками было решено «...урегулировать дело раскопок и хранения древностей». Преподаватель и альпинист Я.И. Фролов во время горных походов собирал предметы из разрушенных в результате хозяйственной деятельности древних и средневековых погребений в верховьях рек Малки и Баксана на территории нынешней КабардиноБалкарской Республики (КБР).

Даже в 1919 г., когда район Кавказских минеральных вод и Терская область были заняты Добровольческой армией А.И. Деникина, Рим-Горское городище у Кисловодска продолжал посещать и фотографировать член КГО Г.И. Раев, а во Владикавказе 2 кургана раскопал археолог М.А. Радищев.

Когда после сложного периода становления в 1919-1920 гг. РАИМК развернула свою деятельность по разработке перспективных планов, созданию этнологоархеологических комиссий (ЭАК), организации региональных экспедиций и пр., в том числе и в некоторых районах страны после восстановления там советской власти, она опиралась на сохранившиеся там заинтересованные кадры. На Северном Кавказе ЭАК 
планировалось создать в ряде городов (Краснодар, Ставрополь, Пятигорск, Владикавказ). В Пятигорске к этому были привлечены Д.М. Павлов и поселившийся на курорте в 1920 г. археолог и деятель сферы сохранения культурного наследия и музейного строительства В.Р. Апухтин. В 1920 г. ими был образован Совет обследования и изучения Терского края. Прикумское (Пятигорское) отделение Северо-Кавказской ЭАК (г. Краснодар) было создано специальным Постановлением РАИМК от 26.06.1921 г. Председателем его стал Д.М. Павлов, третьим членом - этнолог И.П. Дриженко. Среди планируемых задач значилось развертывание изучения городищ Рим-Гора и Маджары, выявление, учет и картографирование других объектов. Но, создавая свои структуры на местах, переживавшая материальные трудности Академия часто не обеспечивала выделения необходимых средств. Это стало препятствием в налаживании работы Пятигорского отделения.

Не удалось развернуть работу ЭАК и во Владикавказе. Там с 1920 г. на базе Терского областного музея, где с 1907 по 1926 г. работал Северокавказский институт краеведения (затем преобразованный в Ингушский НИИ краеведения), а также археологоархитектурными исследованиями в Осетии и Ингушетии занимались профессор Л.П. Семенов и художник-архитектор И.П. Щеблыкин (Семенов, 1928).

Самым удачным стал опыт создания ЭАК в Ставрополе Г.Н. Прозрителевым (1849-1933). Она действовала с 1921 г. вплоть до смерти руководителя (Колесникова, 2001.С. 208-224). Этот успех во многом зиждился на осознанном энтузиазме Прозрителева. Но работа этой комиссии непосредственно не затрагивала районы Кавминвод и Терека. Был и еще один более поздний пример создания местных структур ГАИМК на Северном Кавказе - образование в 1929 г. Дагестанского комитета при Академии. Однако районы нижнего Терека в рассматриваемый период почти не подвергались археологическому изучению.

Более эффективно складывалась работа созданной РАИМК под руководством заведующего Разрядом палеоэтнологии профессора А.А. Миллера Северо-Кавказской этнолого-археологической экспедиции (СКЭ), планы которой определялись в 1922-м (изучение чеченских и ингушских башен, северокавказских каменных статуй и пр.), а начали реализоваться в 1923 году. Подспорьем для формирования кавказских интересов А.А. Миллера были его работы 1917 г. в округе города Нальчика с еще одним будущим сотрудником РАИМК (с 1924 г.) С.Н. Замятниным. В 1923 г. удалось побывать только в музее во Владикавказе и проехать в Дигорию для осмотра могильников. В 1924-1925 гг. работы экспедиции велись на территории Кабардино-Балкарии. В Нальчике членом экспедиции стал известный местный энтузиаст М.И. Ермоленко, создавший 1921 г. Кабардинский областной музей и формировавший его археологические коллекции. Не имея средств, Ермоленко обращался за помощью в Пятигорск к Д.М. Павлову как руководителю Северо-Кавказского комитета по делам музеев, а затем установил связи с сотрудниками СКЭ экспедиции РАИМК. Он повлиял на планы работы экспедиции, а в 19321933 гг. с его подачи стали изучаться эталонные памятники неолита и энеолита в Нальчике (Агубековское, Долинское поселения, Нальчикский могильник и др.).

С 1926 г. работы Северо-Кавказской экспедиции велись в Горной Осетии, где, при участии профессора А.А. Фраймана, изучался традиционный живой быт, но затрагивались и археологические объекты. Обследовались и районы Кабардино-Балкарии. Масштабные исследования бытовых объектов Кабарды и Пятигорья готовились в 1928 г. и были осуществлены в 1929-1930 гг. Тогда оформились контакты А.А. Миллера и ответственного исполнителя работ А.А. Иессена с директором Пятигорского окружного музея археологом Н.М. Егоровым, который с 1924 г. занимался выявлением памятников и пополнением археологических коллекций (Савенко, 2017. С. 57-68). Эти связи также влияли на дальнейшие планы экспедиции, в частности, по работам 1935-1936 гг. на погребальных и бытовых памятниках эпохи бронзы, скифо-сарматского времени и раннего средневековья в районе Моздокского карьера. В 1932 г. большие работы были проведены на Баксанстрое, ставшим в следующем году сотрудником СКЭ ГАИМК Б.Е. Дегеном-Ковалевским. В 1933 г. А.А. Иессен вел разведки в горных районах бассейна Терека, а в 1935 г. создана специальная хоздоговорная Терская экспедиции ГАИМК под ру- 
ководством А.П. Круглова, который обследовал средневековые поселения, церкви, башни, могильники и вел небольшие раскопки. В 1936 г. А.П. Круглов возглавил ЧеченоИнгушскую экспедицию, которая также занималась разведками и ограниченными раскопками.

В результате работ ГАИМК, осуществляемых в сложной обстановке (финансовые проблемы, структурные преобразования, идеологический прессинг, репрессии в отношении краеведов и этнологов) были учтены известные, выявлены и частично исследованы новые памятники в регионе, накоплен материал от эпохи камня до позднего средневековья, послуживший основой для научных обобщений. Устанавливались конструктивные деловые связи с местными организациями и специалистами.

\section{ЛИТЕРАТУРА}

Ермоленко Л.П., 2017. Развитие региональной археологической науки во второй половине XIX - первой четверти XX столетия (по материалам Северного Кавказа) // Гуманитарные и юридические исследования. Серия - История и исторические науки. - Ставрополь: СКФУ. С. 58-64.

Колесникова M.E., 2001. Ставропольская этнолого-археологическая комиссия. Страницы истории и основные направления культуроохранительной деятельности в 1921-1933 годах // Материалы по изучению историко-культурного наследия Северного Кавказа. Вып. II. Археология. Антропология. Палеоклиматология. М.: Памятники исторической мысли. С. 208-224.

Мерперт Н.Я., 1995. Введение // Антология советской археологии. Т. I. 1917-1933. М.: ИА РАН-ГИМ. С. 3-14.

Платонова Н.И., 2010. История археологической мысли в России. Вторая половина XIX - первая четверть XX века. СПб.: Нестор-История. 316 с.

Савенко С.Н., 2017. Научные и личные контакты Н.М. Егорова и крупного кавказоведа Александра Александровича Иессена (1896-1964) // Третий Кавминводский межрегиональный музейно-научный семинар памяти краеведов: материалы заседаний. Ставрополь: Печатный двор. С. 57-68.

Семенов Л., 1928. Археологические и этнографические разыскания в Ингуши в 1925-27 г.г. Владикавказ: Ингушский НИИ краеведения. 32 с.

https://doi.org/10.25681/IARAS.2019.978-5-94375-275-9.43-45

И.А. Сорокина

(Москва)

\section{О ПОЛЕВОЙ АРХЕОЛОГИИ ПЕРВЫХ 15-и ЛЕТ СОВЕТСКОЙ ВЛАСТИ} (1918-1932)

Археология, особенно полевая, тесно связана с развитием государства и событиями, в нем происходящими - такова уж особенность нашей науки. Обусловлено это, вопервых, собственностью на землю (поскольку памятник археологии находится в земле), во-вторых, возможностями финансирования полевых исследований. На состояние полевой археологии непосредственно влияют революции, войны резкие смены внутриполитического курса. Все эти явления в России сконцентрировались в сжатые хронологические рамки: от смены власти в результате Октябрьского переворота 1917 г. до перехода к мобилизационной модели развития экономики в 1928 г. За это время сменились два внутриполитических курса: «военный коммунизм» (1918-1920) и НЭП (1921-1927). Важной особенностью исторического момента стали и социальные перемены. Если до 1918 г. археологией занималась небольшая «имущая» часть российского общества (археологи, коллекционеры), то с начала 1920-х гг. изучением материальной культуры и истории Отечества заинтересовались многочисленные краеведы (местная новая интеллигенция) и, наконец, народные массы, получившие доступ к активно создаваемым музеям и образованию. 
Повлияли на специфику периода и законодательные изменения, в первую очередь, отмена частной собственности на землю. Уже в 1918 г. последовали первые распоряжения новой советской власти в отношении культурного наследия и науки. Декрет СНК от 05.10.1918 г. не содержал пунктов об археологическом наследии, но косвенно затрагивал вопрос об археологических памятниках и коллекциях, которые необходимо было регистрировать. А позже появляется уже полноценное охранное законодательство, непосредственно определяющее судьбу археологического наследия: Декрет ВЦИК и СНК от 7.01.1924 г. и в качестве подзаконного акта - «Инструкция» по его практическому применению на местах.

Регламентацию полевой археологии в рассматриваемый период осуществляли две организации. Это созданный 1918 г. в Москве административный орган - Археологический подотдел (АПО) Отдела по делам музеев и охране памятников искусства и старины в системе Наркомпроса РСФСР и Российская академия истории материальной культуры (РАИМК), учрежденная специальным Декретом СНК в апреле 1919 г. в Петрограде, подчиненная также Наркомпросу, но другому его отделу - Научному. Таким образом, административная и научная составляющие регламентации должны были дополнять друг друга. Открытый лист на полевые работы выдавался АПО по заключению РАИМК об их целесообразности и квалификации исследователя. Но на практике возник конфликт двух учреждений, во многом определявшийся личностным фактором: неприятием заведующим АПО В.А. Городцовым системы существующей в России с 1889 г. регламентации и РАИМК как значимого археологического учреждения.

Означенное противостояние крайне негативно сказалось на разработке методики полевой археологии. За 30 лет, предшествовавших Первой мировой войне, было издано 7 полноценных (по меркам того времени) пособий по методике проведения полевых изысканий, подготовке научной документации и работе с коллекциями (авторы Д.Я. Самоквасов, А.А. Спицын, В.А. Городцов). И дальнейшие шаги, несомненно, делались бы, но помешали война и смена государственных устоев. А в первые годы советской власти, несмотря на наличие мощных научных сил в основных центрах - двух столицах, не только новые разработки, но и хотя бы краткие инструкции к открытым листам отсутствовали. Для сохранения археологических памятников и развития науки это было катастрофой, так как социальная база общественности, стремящейся к ведению полевых работ, как уже было сказано, существенно расширилась. В АПО непрерывно стекались сведения о варварских раскопках без открытых листов и до, и, к сожалению, после принятия Декрета 1924 г., в котором была обозначена ответственность за подобные деяния вплоть до уголовной. Настоящим бедствием стала активность школьных учителей, стремящихся расширить кругозор учащихся посредством раскопок (точнее, разрытия) близлежащих памятников, особенно небольших курганов. Наркомпрос даже вынужден был разослать циркулярное распоряжение, обязывавшее местные власти и отделы народного образования пресекать такую практику.

Работа по установлению как методических основ, так и правопорядка в системе выдачи открытых листов началась только с приходом в Отдел музеев видного археолога Б.С. Жукова, сменившего в конце 1926 г. В.А. Городцова на посту заведующего археологическим подразделением. В корне изменились отношения с Академией истории материальной культуры (теперь ГАИМК, преобразована из РАИМК в 1926 г.), которой отводилась уже никем не оспариваемая роль научно-консультативного органа. Наступил период сотрудничества двух учреждений: административного и научного. В результате в 1927 г. появилась обязательная для всех исследователей на территории РСФСР инструкция к открытым листам (Инструкция...,1927), а также методическое пособие по археологическим разведкам без вскрытия слоя А.А. Спицына (Спищын, 1927), адресованное краеведам.

Рассмотрим некоторые тенденции в развитии полевой археологии рассматриваемого времени. Анализ возможен благодаря уникальной базе данных по полевой археологии с 1859 по 2010 г., разрабатываемой нами на протяжении ряда лет. Данные с 1919 по 1932 г. внесены из разных источников: документы ГАРФ и Научного архива ИИМК РАН, до- 
вольно многочисленные обзоры полевых исследований в разных регионах или по стране в целом (например: Археологические..., 1962; Городияов, 1928; Жуков, 1926). Всего за этот период учтено 1249 исследований, проведенных как по открытым листам, так и без оных. Сведения о последних происходят не только из архивных источников и официальных обзоров, но и упоминаниях в литературе, посвященной описанию археологических памятников регионов или истории учреждений археологического профиля в них.

Количество работ в 1918-1919 гг. ничтожно мало по сравнению с довоенным периодом (для сравнения в 1914 г. зафиксировано 90 исследований, а в 1919 - всего 10). Помимо общего истощения сил и ресурсов сказалась еще и значительное уменьшение территории Советской России. После революций 1917 г. отпала часть губерний Российской империи, а во многих оставшихся начиналась Гражданская война с образованием местных «правительств»). В 1921 г., с началом НЭП, их количество увеличивается до 38, но настоящий рост начинается в 1923 г. (69 исследований). Этот факт отмечал и заведующий АПО В.А. Городцов. Причина - в улучшении экономической ситуации после отмены «военного коммунизма». У местных музеев и иных организаций появляются средства на раскопки. Именно тогда и начинается массовое краеведческое движение, оживившее культурную жизнь провинции. В 1927 г. количество проведенных работ возрастает уже в 2,5 раза - до 247. Отметим, что это совпадает с упорядочиванием выдачи открытых листов, появлением инструкции и пособия А.А. Спицына. Причем на разведки выдано листов больше, чем на раскопки. Это, как раз, и есть лучшее применение для краеведов, не имеющих подготовки для полноценных научных раскопок. Появляется много новых имен, большая часть которых в дальнейшем, к сожалению, не встретится. В 1929 г. начинается резкий спад, несомненно, обусловленный разгромом краеведческого движения в государственных масштабах. В результате к 1931 г. количество полевых исследований сокращается в 5,5 раз (!) и только в 1932 г. незначительно начинает расти, что связано с началом больших новостроечных проектов, реализованных уже не краеведами, а археологами-профессионалами. Такова страшная цена репрессий, на долгие годы затормозивших изучение и сохранение археологического наследия советского государства.

\section{ЛИТЕРАТУРА}

Археологические экспедиции ГАИМК и ИА АН СССР: 1919-1956 гг. 1962. М. Изд-во АН СССР. 264 с.

Городизов B.A., 1928. К итогам археологических трудов в СССР за 10 лет // ТСА РАНИОН. Вып. 2. С. 5-11.

Жуков Б.С. Работы по палеоэтнологии в СССР за 1918-1925 гг. Этнография, 1926, № 1-2. С. 179-192.

Инструкция..., 1927. Инструкция к открытым листам на право производства археологических раскопок и обследований // Еженедельник Народного комиссариата просвещения. № 27. Ст. 651.

Спищы А.A., 1927. Разведки памятников материальной культуры. Пособие для краеведов. Л: ЦБК. 142 с.

https://doi.org/10.25681/IARAS.2019.978-5-94375-275-9.45-48

Д.А. Сташенков

(Самара)

\section{АРХЕОЛОГИЧЕСКИЕ РАБОТЫ В САМАРСКОЙ ГУБЕРНИИ НА ПЕРЕЛОМЕ ЭПОХ: 1918-1930 ГОДЫ}

Археологические работы в Самарской губернии в 1918-1930 гг. проводились сотрудниками различных общественных и государственных организаций.

К 1918 г. относятся последние полевые работы членов созданного в 1916 г. Самарского археологического общества (CAO) - раскопки мордовского могильника на Барба- 
шиной поляне, организованные К.П. Головкиным и Ф.Т. Яковлевым. Не исключено, что после отъезда К.П. Головкина из Самары небольшие работы на Барбашинском могильнике летом 1919 г. уже самостоятельно осуществил Ф.Т. Яковлев. Необходимо отметить, что раскопки проводились в рамках разработанной в Обществе программы археологических исследований на территории Самарской губернии, а сама программа, по сути, являлась личным делом членов САО (Стаменков, 2017).

Ситуация изменилась после того, как в октябре 1918 г. Советом Народных Комиссаров был издан Декрет «О регистрации, приеме на учет и охранении памятников искусства и старины, находящихся во владении частных лиц, обществ и учреждений». С этого момента охрана и изучение памятников истории становятся государственным делом. Работы по регистрации и по выявлению памятников, подлежащих учету, возлагались на Комиссии по охране и регистрации памятников искусства и старины (в Москве и Петрограде), а на местах - на губернские Советы рабочих и крестьянских депутатов и отделы народного образования. Для передачи информации о памятниках искусства и старины в соответствующие органы со дня опубликования Декрета (10 октября 1918 г.) отводился месячный срок.

Выполнить подобную работу в столь сжатые сроки на местах было невозможно, к тому же в Самаре отсутствовала не только официальная государственная структура, которая отвечала бы за учет и сохранение памятников, но и квалифицированные специалисты, способные объективно оценить значимость предлагаемых к охране памятников. Вопрос не был решен и после создания в Самаре отдела по делам музеев и охраны памятников искусства и старины, и даже после того, как на должность заведующего музейной секцией внешкольного подотдела губернского отдела народного образования была приглашена профессиональный археолог и музейный работник - В.В. Гольмстен, приехавшая в Самару летом 1919 г. (Кузьминых, Сафонов, Сташенков, 2007. С. 15).

Стало очевидным, что силами нескольких чиновников без помощи специалистов наладить системную работу по учету и сохранения памятников было невозможно.

2 ноября 1919 г. было создано Общество археологии, истории, этнографии при Самарском университете. В этот же день по решению общего собрания членов САО присоединилось, «сохраняя свою полную самостоятельность, к общей научной организации университета под именем "Общество археологии, истории, этнографии при Самарском государственном университете”» (Крайнова, 1995а. С. 136).

С этого времени археологические исследования в регионе инициировались уже не членами САО, которые больше не фигурировали в качестве основных исполнителей археологических работ, а членами Общества археологии, истории, этнографии (с 1923 г. и естествознания) при Самарском университете, преподавателями Самарского университета и Высших этнолого-археологических курсов, работниками губернского (краевого) музея при официальной поддержке властных структур.

В 1921 г. при непосредственном участии В.А. Городцова была разработана программа археологического обследования Самарской губернии, намечены основные разведочные маршруты. Формальным лидером самарских археологов в это время считался А.С. Башкиров, но вскоре на первый план в деле организации полевых работ вышла В.В. Гольмстен.

Нужно отметить, что при проведении планомерных работ в Самарской губернии в 1920-е гг. широко использовались возможности различных образовательных учреждений. Так, весной 1920 г. для подготовки работников в области археологии, архивоведения, этнографии, музееведения и библиотековедения были созданы Высшие этнологоархеологические курсы. Руководителем курсов первоначально был академик В.Н. Перетц, с 1922 г. - профессор П.А. Преображенский, секретарем - профессор В.В. Гольмстен. Сначала срок обучения на курсах был 6 месяцев, затем он был увеличен до двух лет. Нужно отметить, что слушателями курсов зачастую становились лица с высоким образовательным уровнем. Например, в 1923 г. среди 68 принятых на курсы слушателей преобладали лица с высшим образованием (газета «Коммуна», 03.11.1923). Лица, не имевшие высшего образования, окончив курсы, получали право поступать на третий 
курс в ведущие университеты страны, в частности, Московский, чем и воспользовались некоторые выпускники. Известно, например, что студентом Московского университета в 1927 г. стал А.А. Марущенко, ученик В.В. Гольмстен.

Уже летом 1920 г. Обществом археологии, истории и этнографии на дюнах р. Самары в Бузулукском уезде и в окрестностях Самары проводились комплексные археологические исследования под руководством В.В. Гольмстен, организованные в форме практических занятий по археологии со слушателями археологических курсов. Практической целью занятий было получение слушателями курсов знаний о методике проведения археологической разведки и основах археологических раскопок, ведения полевой археологической документации. Под руководством геолога П.Н. Ефимова проводились практические занятия по топографической съемке местности и описанию геологических разрезов.

На масштабе археологических работ в регионе сказались как ликвидация Самарского университета в 1922-1923 гг., так и реорганизация в 1925 г. Высших этнологоархеологических курсов (они стали называться Высшими курсами краеведения), срок обучения на них сократился до одного года. Соответственно сократились и возможности для привлечения слушателей курсов к проведению археологических работ в губернии.

Начиная с 1922-1923 гг. происходит инициированная властями постепенная переориентация деятельности членов общества на изучение природных особенностей края, составление геологической карты губернии, выявление тех ресурсов, которые непосредственно могли бы быть использованы в народном хозяйстве.

Несмотря на то, что до конца 1920-х гг. в документах встречаются упоминания Общества археологии, истории, этнографии и естествознания в г. Самаре, уже как минимум с 1924 г. в официальных бумагах фигурирует и Самарское краеведческое общество. Плодотворную работу Самарского краеведческого общества, которое с 1924 г. работало как «самостоятельная организация, находясь в ведении Главнауки Наркомпроса», отмечало Центральное бюро краеведения (Крайнова, 1995б. С. 155). В 1924 г. в состав Центрального бюро краеведения была избрана В.В. Гольмстен.

Члены СОАИЭиЕ (В.П. Арапов, В.В. Гольмстен, П.А. Преображенский, А.Ф. Терехов и др.) принимали активное участие и в работе губернской краеведческой комиссии, образованной в январе 1925 г.

Масштабы краеведческой работы изменились после административной реформы 1928 г. В мае 1928 г. была образована Средне-Волжская область, в состав которой вошли территории из четырех бывших губерний - Самарской (без Бугульминского и Пугачевского уездов), Оренбургской, Пензенской и части Саратовской.

В ноябре 1928 г. в серии постановлений Президиум Средне-Волжского облисполкома связал задачи ускорения роста народного хозяйства и всестороннего развития краеведения, которое с этого момента получало планомерный характер, что привело к окончательному смещению акцента в сторону естественнонаучных исследований. Официальным закреплением этого факта в 1929 г. явилась реорганизация СОАИЭиЕ в Самарское окружное краеведческое общество и создание Областного бюро краеведения, в составе которого археологов уже не было.

После отъезда в 1929 г. из Самары В.В. Гольмстен планомерные археологические работы в регионе сворачиваются. В 1930 г. состоялась последняя экспедиция В.В. Гольмстен на Самарскую Луку.

Летом 1930 г. по предложению КрайОНО Общество приняло решение передать Археологический музей Самарскому краевому музею. Часть собранных коллекций была передана Государственному Эрмитажу и Академии истории материальной культуры, библиотека - Самарскому педагогическому институту (Крайнова, 1995б. С. 159). Эти обстоятельства подвели черту под этапом активного археологического изучения региона.

Таким образом, в изучении Самарского Поволжья в 1918-1930 гг. можно выделить четыре периода:

1. 1918-1920 годы. Время становления. В этот период происходил переход от любительских исследований членов Самарского археологического общества, не имевших базовой археологической подготовки, к целенаправленному изучению территории Са- 
марской губернии, координирующемуся Обществом археологии, истории и этнографии при Самарском государственном университете. Новые работы официально поддерживались государственными структурами.

2. 1921-1924 годы. Период активного разведочного обследования территории Самарской губернии. Работы проводились профессиональными археологами, объединенными в единый коллектив под руководством профессора В.В. Гольмстен. После закрытия Самарского университета в 1923 г. интенсивность работ снижается.

3. 1925-1928 годы. Период первоначального обобщения полученного материала. Подготовка серии работ по археологии Самарского Поволжья, построение схемы археологического развития региона, научное формирование и описание археологической коллекции в губернском музее, оформление цельной археологической музейной экспозиции в Археологическом музее СОАИЭиЕ.

4. 1929-1930 годы. Сворачивание археологических исследований в регионе. Ликвидация СОАИЭиЕ, Археологического музея и библиотеки Общества. Окончательная переориентация официальных органов на поддержку естественнонаучного краеведения.

\section{ЛИТЕРАТУРА}

Крайнова Т.В., 1995а. Самарское археологическое общество (1916-1919) // Краеведческие записки. Выпуск VII / Отв. ред. П.С. Кабытов. Самара: СамВен-СОИКМ им. П.В. Алабина, 1995. С. 134-136.

Крайнова Т.В., 1995б. Самарское общество археологии, истории, этнографии и естествознания при Самарском государственном университете (1919-1929) // Краеведческие записки. Вып. VII / Отв. ред. П.С. Кабытов. Самара: СамВен-СОИКМ им. П.В. Алабина, 1995. С. 137-62.

Кузьминых С.В, Сафонов И.Е., Сташенков Д.А., 2007. Вера Владимировна Гольмстен: Материалы к биографии. Самара: Офорт. 168 с.

Сташенков Д.А. Археологические исследования в Самарской губернии в 1910-1920-е гг. // 1917 год: российская археология на переломе эпох. Материалы Международной научной конференции / Отв. ред. И.А. Сорокина. М.: Институт археологии РАН. 2017. С. 69-72.

https://doi.org/10.25681/IARAS.2019.978-5-94375-275-9.48-50

И.Л. Тихонов

(Санкт-Петербург)

\section{СТАНОВЛЕНИЕ СИСТЕМЫ АРХЕОЛОГИЧЕСКОГО ОБРАЗОВАНИЯ В ПЕТРОГРАДЕ (1918-1925)}

Вопрос о преподавании археологии в русских университетах обсуждался уже на первых Всероссийских археологических съездах. Хотя предлагаемая кафедра археологии так и не появилась в университетах в дореволюционный период, археология в начале XX в. была довольно широко представлена в разных учебных курсах СанктПетербургского университета (Тихонов, 2003). С 1878 г. работал Петербургский археологический институт, ориентированный в основном на подготовку архивистов. Возникновение системы подготовки профессиональных археологов происходило уже в новых условиях послереволюционного времени. Две революции 1917 года, сломавшие старый бюрократический аппарат, «развязали руки» инициативе научного сообщества.

Весною 1918 г. началась реорганизация Археологического института, в котором преподавание археологии до этого времени было весьма скромным. Инспирирована она была самими членами института, которые стремились превратить его в полноценное высшее учебное заведение и доказать полезность существования для новой власти. Уже с начала 1918 г. Археологический институт сотрудничал с ней, выполняя ее распоряжения. В марте Наркомат Просвещения даже предоставил институту новое помещение на Фонтанке, 22. 
Основными направлениями реорганизации стали: превращение института в специальное высшее учебное заведение, увеличение срока обучения до 3 лет, расширение учебного плана и разделение на факультеты. Первоначально рассматривался проект разделения института на три отделения: археологическое, археографическое, истории искусств. Но в итоге к 1920 г. было создано два факультета: Археографический и Археологический с 11 кафедрами. Значительно расширился состав преподавателей, к 1921 г. в Археологическом институте стало 25 профессоров, 5 преподавателей, 2 ассистента, по сравнению с 1914 г. (7 профессоров, 6 преподавателей и 4 лектора). Профессорами института стали А.А. Миллер, Б.В. Фармаковский, С.А. Жебелёв, Д.В. Айналов, Н.П. Сычёв, Г.И. Боровко, К.К. Романов, Н.Н. Бауер. Продолжал преподавать А.А. Спицын.

Учебный план факультета, включавший в себя как общие, так и частные дисциплины, позволял обеспечить высокий уровень археологического преподавания и подготовки кадров археологов. Но уже с 1920 г. обсуждался вопрос об объединении Петроградского археологического института с Российской академией истории материальной культуры. В итоге, в мае 1922 г. было принято решение о включении института в Университет и создании на его базе археологического отделения факультета общественных наук. Это решение продолжало политику укрупнения учебных заведений. Так еще в 1919 г. в Петроградский университет были влиты Высшие женские (Бестужевские) курсы и Психо-неврологический институт. 30 июня 1922 г. состоялось совещание руководства института с ректором Петроградского университета по вопросу преобразования института в Археологическое отделение университета. На нем было определено: «Отделению предоставить полную внутреннюю автономию. Отпускаемые на его личный состав 40 платежных единиц распределяются по его усмотрению. Сохраняется помещение, канцелярия, бухгалтерия и хозяйственная часть прежнего Института. Все служащие его признаются состоящими на службе в Петроградском университете» (ЦГА СПб. Ф. 2559. ОП. 1. Д. 104. Л. 32). Таким образом, Археологический институт был вовсе не закрыт новой властью, как утверждают некоторые современные авторы, а включен в состав университета. Безболезненности этого слияния способствовало и то обстоятельство, что многие профессора института одновременно являлись и профессорами университета. Первыми студентами археологического отделения также стали слушатели бывшего Петроградского археологического института.

Включением института в состав университета был реализован проект создания университетской структуры по подготовке профессиональных археологов. На археологическом цикле обучалось свыше 60 студентов. Учебный план цикла предусматривал на 1 и 2 курсах лекции по методологии археологических дисциплин, археологии русской и классического мира, доисторической археологии, археологии Древнего Востока и Европы и пр. С 3-го курса студенты специализировались в рамках группы руссковизантийской археологии, группы Дальнего Востока и классического мира, группы доисторической археологии. Здесь продолжалось чтение лекций по отдельным разделам археологии и активно использовался семинарский метод в преподавании. Всего в течение 1924/25 учебного года на археологическом отделении велось 36 семинаров по различным разделам археологии. Преподавательский состав полнился П.П. Ефименко, О.Ф. Вальдгауером, Б.Л. Богаевским, К.Э. Гриневичем, И.А. Орбели, Н.Д. Флитнер, И.И. Мещаниновым.

Летом 1925 г. отделения языкознания, литературы и археологическое были выделены из состава ФОН и образовали факультет языкознания и материальной культуры (ямфак). Учебный план отделения истории материальной культуры на 1925/26 учебный год отличался от прежнего некоторым сокращением как общего числа курсов, так и специальных дисциплин. Однако окончательный учебный план был утвержден Государственным ученым советом только в 1927 г. и в нем мы снова встречаем значительное число лекций и семинаров по разделам археологии (до 20 часов в неделю на 3 и 4 курсе). Срок обучения на ямфаке был увеличен до 4-х лет, вводились дипломные работы, как итог обучения студентов. Открылась аспирантура, первыми аспирантами стали Т.С. Пассек, Б.А. Латынин, М.К. Каргер. 
Археологическое отделение и затем ямфак создали очень эффективную систему подготовки кадров для отечественной археологии. Там получили отличное образование многие выдающиеся представители первого поколения советских археологов. Но усиливающаяся идеологизация гуманитарного образования и «реформаторский зуд» сделали свое дело. Летом 1929 г. ямфак был преобразован в историко-лингвистический факультет, где на отделении истории еще продолжал работать цикл материальной культуры с кафедрами: доисторической археологии, античной археологии, русского искусства и материальной культуры, истории материальной культуры Востока. Однако в следующем году этот факультет был выделен из состава ЛГУ и образовал самостоятельный Историко-лингвистический институт, что привело к фактическому прекращению преподавания археологии. В 1932 г. все имевшиеся археологические коллекции были переданы в Эрмитаж. В результате к середине 1930-х гг. кафедру археологии, по сути дела, пришлось создавать заново.

\section{ЛИТЕРАТУРА}

Тихонов И.Л., 2003. Археология в Санкт-Петербургском университете: Историографические очерки. СПб.: Изд-во СПбГУ. 332 с.

https://doi.org/10.25681/IARAS.2019.978-5-94375-275-9.50-51

А.Н. Ткачёв

(Краснодар)

\section{ЛИЭТО: ПЕРВОЕ АРХЕОЛОГИЧЕСКОЕ ОБЩЕСТВО КУБАНИ}

Возобновление археологического изучения Кубани после Октябрьской революции и Гражданской войны во многом связано с Кубанским педагогическим институтом крупнейшим научным и образовательным центром того времени. На фоне общего подъема краеведения в стране при Кубанском пединституте 23 ноября 1924 г. было открыто Литературно-историческое и этнологическое общество (ЛИЭТО), ставшее первым научным объединением любителей древностей в регионе.

Согласно уставу целью Общества являлось коллективное изучение и проработка вопросов литературы, языка, истории, археологии и этнологии. Общество состояло из 3-х секций: литературной, этнологической и краеведческой (секции местной археологии и истории). Председателем последней был директор Кубанского научного музея А.Ф. Лещенко, секретарем - М.В. Покровский. В состав ЛИЭТО вошло около 50 человек: профессора, преподаватели местных вузов, студенты. (Клочков, 1927. C. 4).

ЛИЭТО стало обществом, собравшим гуманитариев Краснодара тех лет. Среди них были не только энтузиасты-краеведы, но и дипломированные археологи, окончившие Санкт-Петербургский археологический институт (Н.А. Захаров, М.А. Садиленко). Археологические исследования являлись одним из основных направлений его деятельности, что дает основание считать ЛИЭТО первым, в условиях нового времени, научным объединением археологического профиля в регионе.

С самого начала деятельности ЛИЭТО активно сотрудничало со столичными археологами (С.Н. Замятнин, А.С. Башкиров, А.А. Миллер), которые читали доклады, делали сообщения на заседаниях общества и организовывали совместные экспедиции. В первые два года работы на заседаниях общества было прочитано свыше 50 докладов и сообщений, из них 15 - по истории, археологии и антропологии. Вот темы некоторых из них:

- А.Ф. Лещенко «Дольмены на Северном Кавказе»;

- А.Ф. Лещенко, М.В. Клочков «Обследование Таманского полуострова в археологическом отношении летом 1925 г.»;

- М.В. Клочков «Ближайшие задачи историко-археологических работ в Кубанском крае)»; 
- Н.А. Захаров «Летнее обследование окрестностей древней Меотиды»;

- А.С. Башкиров «Итоги археологических работ в Советском Союзе за 1925 год»;

- С.Н. Замятнин «Новейшие открытия в области палеолита. Первобытная стоянка вблизи станицы Ильской».

Первые археологические исследования ЛИЭТО связаны с обследованием наиболее интересных и в то же время подвергаемых разрушению местностей. Проводилась работа с населением, объяснялась необходимость бережного отношения к памятникам и борьбы с кладоискательством. Во время поездок устанавливались связи с местными краеведами. К этой работе члены секции археологии привлекали студентов педагогического института. В 1925 г. ЛИЭТО провело ряд экспедиций: обследован Таманский полуостров, в частности городища у Ахтанизовского гирла, руины Фанагории и станицы Тамань, организована экспедиция в Абинскую долину, где были обследованы орнаментированные дольмены, обследовано городище в станице Некрасовской и могильник в станице Усть-Лабинской, сделаны фотоснимки, собран керамический материал.

В 1926 г. наиболее интересными стали находки черепа пещерного медведя в 5 верстах от Краснодара и палеолитической стоянки на 17-м участке Ильских нефтепромыслов. Наличие стоянки в окрестностях станицы Ильской было давно известно местным научным работникам, но отсутствие средств не позволило приступить в 1925 г. к раскопкам. В 1925 и 1926 годы работы на Ильской стоянке провел С.Н. Замятнин, которому большую помощь оказывал член секции ЛИЭТО, руководитель Ильского кружка краеведения и мироведения, учитель семилетней школы Н.П. Королёв.

Первыми памятниками, которые начали исследовать члены ЛИЭТО, стали городища в Краснодаре и по реке Кубань. В докладе, сделанном на Второй конференции археологов СССР в Херсонесе в 1927 г. говорится уже о десяти обследованных городищах (Захаров, 1927. С. 57). В 1927 г. ЛИЭТО и Кубанский научный музей организовали комиссию по охране памятников старины, находимых на месте строительства районной электростанции (КРЭС) в г. Краснодаре.

К началу 30-х гг. инициатива в изучении памятников археологии Кубани переходит к Краснодарскому историко-краеведческому музею (Н.В. Анфимов, М.В. Покровский), упоминания о ЛИЭТО постепенно теряются. Оценивая итоги деятельности Общества, можно сказать, что многое в его работе было созвучно взглядам палеоэтнологической школы в русской археологии, яркими представителями которой были А.А. Миллер и Б.С. Жуков (работавшие в то время на Кубани). ЛИЭТО следует рассматривать как пример развития региональной археологии в новых реалиях. Начало изучения городищ и могильников раннего железного века Кубани явилось одним из важнейших итогов деятельности общества. Археологи ЛИЭТО, по сути, стали «первопроходцами» науки, первыми, кто после революции принялся за изучение памятников древнего прошлого Кубани.

\section{ЛИТЕРАТУРА}

Клочков М.В., 1927. Краткий обзор деятельности Литературно-исторического и этнологического общества // Сборник статей по экономике и культуре. Вып. 1. (Труды СКАНИИ. № 26). Краснодар. С. 1-6.

Захаров Н.А., 1927. Первые шаги систематического изучения городищ Северозападного Кавказа // Вторая конференция археологов СССР в Херсонесе 10-13 сентября 1927 г. Севастополь. С. 56-57. 


\section{В.В. ЛАТЫШЕВ: НЕРЕАЛИЗОВАННЫЕ ПРОЕКТЫ 1917-1921 ГОДОВ}

Исследование проведено при финансовой поддержке гранта РФФИ. Проект № 18 09-40116 (конкурс «Древности»).

Академик РАН и член-корреспондент Афинской, Берлинской Парижской и Римской академий наук Василий Васильевич Латышев (1855-1921) в революционное время и годы Гражданской войны оставался в должностях товарища председателя Императорской археологической комиссии (с 23 мая 1917 г. Российской археологической комиссии, с июня 1918 г. Российской государственной археологической комиссии) и члена совета РГАК (с 24 сентября 1918 г.). Тайный советник, член Совета министра народного просвещения (до 1917 г.), вплоть до 22 августа 1918 г. он являлся директором своей alma mater - Петроградского историко-филологического института. Но эту должность ученый покинул по собственному желанию после «внутреннего переворота [в институте. - И.T.], который так неблагоприятно отразился на его душевном настроении и физическом благосостоянии, что уже через полгода жизнь его была на волоске от смерти», вспоминал его младший коллега академик А.В. Никитский (СПбФ АРАН. Ф. 84. Оп. 1. Д. 36. Л. 16 об.). К началу апреля 1919 г. из-за хронического недоедания и психологического дискомфорта В.В. Латышев болел миокардитом, осложненным тяжелым фурункулезом. После отставки ученый вынужден был оставить казенную квартиру и перебраться на другую. В сентябре 1918 г. академик получил удостоверение РАН в том, что В.В. Латышев «не подлежит отбыванию трудовой повинности вне места служения», а также охранную грамоту на квартиру и библиотеку (СПбФ АРАН. Ф. 2. Оп. 17. Д. 81. Л. 32-35).

В пред- и революционные годы В.В. Латышев являлся председателем нескольких комиссий Российской академии наук, в том числе Издательской, по созданию Палестинского комитета при Императорской АН с целью организации Русского археологического института в Иерусалиме для изучения Палестины и сопредельных стран, по охране земельных участков с памятниками археологическими (1917), Комиссии по изучению творений Константина Багрянородного и его эпохи (1918), представителем РАН в Комитете русской иконописи (1919). С апреля 1919 г. он принял на себя заведование библиотекой и архивом «Византийского временника» (СПбФ АРАН. Ф. 2. Оп. 17. Д. 81. Л. 41, 46; Ф. 110. Оп. 1. Д. 103. Л. 136-137 об., 150, 186-189, 191, 194, 196, 197, 199, 200 , $207,212)$. Однако в 1918-1920 гг. работа практически всех академических комиссий была парализована из-за «общего расстройства» дел Российской академии наук. Помимо этого, В.В. Латышев являлся членом Русского археологического общества, председателем Отделения научных изданий Православного Палестинского общества, председателем Общества классической филологии и педагогики.

13 ноября 1918 г. РГАК возглавил в качестве председателя академик Н.Я. Марр, главный инициатор создания на ее базе РАИМК в составе Наркомпроса. Летом 1919 г., наряду с академиками С.Ф. Ольденбургом, Н.Я. Марром, В.В. Бартольдом и Б.А. Тураевым, В.В. Латышев был избран членом РАИМК. Академик стал заведующим Разряда древностей греческих колоний на юге России и первоначально имел в штате одного сотрудника - Е.М. Придика, работавшего над корпусом керамических клейм. В 1920 г. к нему присоединился эпиграфист академик А.В. Никитский.

8 декабря 1919 г. на заседании Археологического отдела, в который входил разряд, В.В. Латышев предложил подготовить к изданию «Реальную энциклопедию юга России и Кавказа классической и византийской эпох» со строго фактическим изложением материала по образцу известной немецкой энциклопедии науки о классической древности «Realencyclopädie der classischen Altertumswissenschaft» Паули-Виссовы. Из-за отсутствия средств в Русском археологическом обществе в 1919-1921 гг. все незавершенные 
проекты В.В. Латышева были переданы из РАО в РАИМК: продолжение второго издания корпуса древнегреческих и латинских надписей Северного Причерноморья (IosPE), подготовка к изданию третьего тома IosPE (корпус керамических клейм), издание третьего тома свода известий древних авторов о Скифии и Кавказе "Scythica et Caucasica. Известия древних писателей о Скифии и Кавказе» с эксцерптами из византийских писателей и составление указателей к первым двум вышедшим томам, исправленное и дополненное переиздание «Сборника надписей христианских времен из южной России». Идея нового издания свода христианских надписей совместно с РАО была поддержана II Археологическим отделением и Правлением РАИМК в январе-марте 1921 г. Ученый планировал создать также Эпиграфический музей при РАИМК, куда собирал надписи и эстампаж и с них. Но все эти проекты остались нереализованными перед смертью он лишь успел подготовить к печати фрагменты из сочинений 20 византийских авторов о Северном Причерноморье и Кавказе и составить указатели к первым двум томам «Scythica et Caucasica», но они в свет не вышли. Как вспоминал академик А.В. Никитский, В.В. Латышев «продолжал ученые труды свои буквально до смерти, как ни затруднена была в эти годы работа и хотя при невозможности или трудности заграничных и внутренних ученых сношений ему приходилось изыскивать новые для него области приложения ученого труда, без которого он не мог жить, по независящим от него причинам остались ненапечатанными около десятка или больше работ этого времени». К счастью, большинство неизданных рукописей сохранилось в личном фонде В.В. Латышева в Санкт-Петербургском филиале Архива РАН (фонд № 110).

В.В. Латышев скончался от болезней, голодного и психологического истощения 2 мая 1921 г. в Петрограде. Основная заслуга ученого перед мировой наукой состоит в том, что благодаря ему эпиграфические и литературные свидетельства античных и византийских источников стали достоянием широких кругов специалистов: составленные им эталонные своды до сих пор являются настольными книгами всякого историка и археолога, работающего в области древней истории Европейской России и Кавказа (Тункина, 1999. С. 221). Именно поэтому неизданные труды ученого требуют скорейшего ввода в научный оборот.

\section{ЛИТЕРАТУРА}

Тункина И.В., 1999. В.В. Латышев: Жизнь и ученые труды (по материалам рукописного наследия) // Рукописное наследие русских византинистов в архивах СанктПетербурга / Под ред. чл.-корр. РАН И.П. Медведева. СПб.: Дм. Буланин. С. 172-288.

\section{ПОПЫТКА ОРГАНИЗАЦИИ АРХЕОЛОГИЧЕСКИХ ИССЛЕДОВАНИЙ В СТАЛИНСКОМ МУЗЕЕ КРАЕВЕДЕНИЯ (ДОНБАСС, КОНЕЦ 20 - НАЧАЛО ЗО-Х ГОДОВ ХХ ВЕКА)}

Краеведческий музей в городе Сталино (ныне Донецк) создан в 1924 г. Впрочем, довольно долго после этого музей никак не мог стать на ноги - выделялись мизерные средства, не было постоянного помещения, не хватало специалистов, часто менялись заведующие. Например, в 1929 г. музей, судя по документам Наркомпроса, «перебував у жахливому стані, не міг розгорнути науково-краєзнавчої діяльності» (Яненко, 2016. C. 80). Еще осенью 1930 г. поднимались вопросы о переведении Сталинского музея на госбюджет. Вопрос же о постоянном здании в довоенный период так и не был решен.

Но, несмотря на организационные трудности, молодой музей, судя по сохранившимся документам, довольно быстро освоился в вопросах организации этнографических и археологических исследований. Как отмечает в рукописном отчете временный сотрудник музея тех лет В.М. Евсеев (орфография документа сохранена): «Осенью 
1929 года заведывающий Сталинским музеем краеведения О.В. Якубский (1) едет по маршруту: с.с. Ясиновка, Землянки, Амвросиевка, Белояровка, Успенка. О. Якубский поставил себе главной целью из'ятие из церквей старинных культовых вещей и документов и между прочим в селах Белояровка и Успенка поискать кремня (мастерских). ... На правом берегу р. Крынки под. с. Белояровкой был осмотрен участок поля, усеянный кремнем. Якубским был подобран кремень ... носивший следы обработки. В с. Успенке учениками были нам принесены: - прекрасный нуклеус и несколько осколков кремня с ясной обработкой на них. ... 1. С О.В. Якубским ездил студент В. Евсеев. ...» (Усачук, Колесник, 2012. С. 7). Судя по сохранившейся документации, разведки в ноябре 1929 г., проведенные О.В. Якубским и тогда еще студентом В.М. Евсеевым можно считать первыми этнографо-археологическими работами, проведенными Сталинским музеем. О.В. Якубский вскоре уехал из Сталино в Житомир (Усачук, Колесник, 2012. С. 10), В.М. Евсеев остался и в дальнейшем сыграл важную роль в становлении музея в Сталино.

Однако только начинавший постигать азы полевой работы В.М. Евсеев не мог пока сам вести какие-то исследования. Но он и остальные не оставляли мыслей организовать-таки археологические работы на базе музея. Об этом свидетельствует интересный документ - письмо нового директора Сталинского музея Л.Д. Мулявки ученому секретарю ВУАК П.П. Куринному от 2 июня 1930 г.: «... пишу Вам зі Сталіного в дуже важливій справі. Річ ось в чому. Вже місяць як я працюю в Сталінському музеї. Цього літа музей гадав розпочати археологічні розкопи. Я енергійно підтримувала цю справу, бо саму мене вразило величезне археологічне багацтво Сталінщини і також велика небезпека, що йому загрожує ... Відзначу велику зацікавленість Сталінських робітників до археологічного минулого округи. Тільки я попала в музей - перше запитання було: коли почнемо копати? ... Запросити будь кого з молодих дослідників ніяк не випадало, бо на Сталінщині, де лише лопата шукала скарбів та може поганенького аматора ворушила могила, перші наукові розкопи матимуть велике агітаційне значення, звернуть на себе увагу суспільства. Так що майбутнє археологічної справи на Сталінщині дуже залежить від цих початкових розкопів. ... Керівні працівники Сталінщини зупинили свою увагу на Макаренкові ... Розкопам тут будуть сприяти.... Коли ж би приїхав який молодий неавторитетний, чи невідомий в Сталіні археолог, то, боюся, що атмосфера для нього і для розкопів, взагалі, склалася би не зовсім сприятлива, поскільки приїзд не тої людини, що чекали до певної міри розчарував би Сталіне ...» (Мулявка, 1930). В письме впервые упоминается маститый на то время исследователь - Николай Емельянович Макаренко. Судьба так распорядилась, что Н.Е. Макаренко в 1930 г. действительно стал вести раскопки в Донбассе, но поначалу - по приглашению Мариупольского музея краеведения на территории строящегося завода «Азовсталь», где исследовал знаменитый впоследствии Мариупольский могильник. Однако, в октябре 1930 г. Н.Е. Макаренко раскопал и 4 кургана на окраине города Сталино в районе Азотного завода (ныне завод химреактивов). Эти раскопки - результат усилий Сталинского музея краеведения и местной администрации по привлечению к археологическим работам Н.Е. Макаренко. Из сохранившихся фотографий раскопок, сделанных Н.Е. Макаренко, можно сделать вывод, что В.М. Евсеев участвовал в этих работах, тем самым набирая бесценный опыт.

В конечном счете, за 1930-1933 гг. Н.Е. Макаренко раскопал в Донбассе 22 кургана (г. Мариуроль, г. Сталино и их окрестности). Николай Емельянович так писал, например, Э.Х. Миннзу 27 ноября 1932 г.: «Только что прошедшим летом я работал, как и в прошлом году, исключительно над исследованием культуры скорченных и окрашенных скелетов».

Прошедший под руководством Н.Е. Макаренко в 1930-1931 гг. полевую школу, B.М. Евсеев в 1932 г. провел уже самостоятельные разведки по выявлению археологичеких памятников (Усачук, Колесник, 2012. С. 10-23; Яненко, 2016. С. 339-340), и в том же году - свои первые раскопки курганов (Усачук, Колесник, 2012. С. 23; Яненко, 2016. 
C. 340), положив, тем самым, начало археологическим исследованиям в Донбассе силами сотрудников Сталинского музея краеведения.

\section{ЛИТЕРАТУРА}

Мулявка Л.В., 1930. Шановний Петре Петровичу... НА ІА НАНУ. Ф. 10. Спр. К 55/9. Арк. 11-14 зв.

Усачук А.Н., Колесник А.В., 2012. Виктор Михайлович Евсеев: начало // Літопис Донбасу. № 20. / Гол. ред. А.М. Усачук. Донецьк. С. 4-25.

Яненко А., 2016. Історія музейної археології УСРР (1919-1934). К.: Національний Києво-Печерський історико-культурний заповідник. 368 с.

\section{ОБРЕЧЕННЫЙ АРЬЕРГАРД: «ДЕЛО КРАЕВЕДОВ ЦЧО» 1930-1931 ГОДОВ КАК ТРАГИЧЕСКИЙ ФИНАЛ ОРГАНИЗОВАННОЙ АРХЕОЛОГИИ В РОССИЙСКОЙ ПРОВИНЦИИ}

Уголовно-политическое преследование краеведов Центрально-Чернозёмной области (ЦЧО) последовало сразу за более известным в историографии «академическим делом» (1929-1930 гг.). К этому времени практически все специалисты, кто до и после революции получал открытые листы на раскопки памятников старины и проживал в провинции, состояли членами губернских краеведных объединений или, по крайней мере, сотрудничали с этими вполне советскими структурами. Однако понятное для интеллигентов стремление вписаться в новый порядок жизни, изучая историю, быт и природу родного края, - вроде бы во благо трудящихся - вовлекло их в ловушку. Хотя для галочки среди краеведов числились отдельные пролетарии и даже крестьяне-бедняки, но подавляющее большинство и руководство краеведческих обществ составляли представители «бывших классов» - от учителей, врачей да инженеров до царских чиновников и даже офицеров (в прошлом). Это не удивительно, ведь в большинстве регионов новые кружки любителей старины выросли на базе ученых архивных комиссий, статистических и церковно-археологических комитетов и тому подобных объединений, работавших в империи почти везде с рубежа XIX-XX вв. Так что для ОГПУ лучшей добычи за пределами столичных центров для фабрикации все новых «антисоветских заговоров» было не сыскать.

Повод для нового преследования дал чекистам председатель Воронежского городского и ответственный секретарь Воронежского областного бюро краеведения историк С.Н. Введенский (1867-1940), в прошлом богослов. Он периодически ездил в Ленинград для консультаций с академиком С.Ф. Платоновым, которому вместе с другими учеными чекисты предъявили обвинение в создании мнимого «Всенародного союза борьбы за восстановление свободной России». ${ }^{1}$ В качестве «филиалов» этой мифической «организации» и были представлены группы краеведов из Задонска, Липецка, Острогожска, Тамбова, Орла, Курска, Старого Оскола. По версии следствия, в случае начала интервенции против СССР эти группы на местах должны были «взять власть во избежание анархии». В указанных городах в ноябре 1930 - феврале 1931 года арестовали по нескольку краеведов (от 4 в Курске до 14 в Тамбове). В Воронеже были арестованы еще и представители ряда учреждений и общественных групп, которые будто бы готовились вместе с краеведами свергать советскую власть (бывшие дворяне, офицеры, чиновники, чины полиции, купцы, священнослужители, фотографы, музейные и научные

Здесь и далее заключенные в кавычки выражения - цитаты из следственного дела краеведов ЦЧО, которое из архива ФСБ было передано в Государственный архив общественно-политической истории Воронежской области (Полномочное представительство..., 1931 г.). Полностью протоколы допросов курских арестантов по этому делу факсимильно воспроизведены мной в кн.: Щавелёв, 2007. С. 89-131. 
работники, преподаватели, а также ряд сторожей и безработных). Личные знакомства, нередко случайные, превращались в глазах следствия в свидетельства организации заговора. Так «контрреволюционная организация “Краеведы”» выросла почти до 100 с небольшим «членов».

Единственным доказательством ее существования могли стать и оказались личные признания обвиняемых. К подследственным применялись обычные в практике НКВД этого периода меры воздействия: содержание в промерзших камерах; длительные допросы, угрозы ареста и расстрела членов семьи. В таких условиях одни подследственные дали те показания, которые диктовали им следователи, но несколько обвиняемых сумели выстоять и не оклеветать ни в чем не повинных людей. Среди истинных героев того следствия были Ф.Ф. Руднев из Орла, Н.И. Пузанова, М.А. Резанцев из Курска, а также воронежский профессор М.Н. Крашенинников, которого обвинили в игнорировании марксизма. Хотя эти арестанты ни в чем не признались и не обвинили никого из своих однодельцев, по мнению следователей, «запиравшиеся» оказались «достаточно точно изобличены показаниями других обвиняемых».

Решающим основанием для арестов и обвинения послужили всеобъемлющие признания С.Н. Введенского, названного «главой воронежского центра». Обвинение было направлено в первую очередь против С.Ф. Платонова, которому вменялось в вину превращение Воронежского филиала Археографической комиссии в одно из отделений «контрреволюционного союза». Введенский, сломленный на первом же допросе, не только признал «факт вербовки» его Платоновым, но дал также показания против всех ученых и краеведов, которых он лично знал, включая ленинградцев С.И. Тхоржевского, С.К. Богоявленского, академика А.Е. Ферсмана, И.М. Гревса, Н.П. Анциферова, А.И. Андреева, против москвича академика М.М. Богословского и своих товарищей по Курскому краеведческому обществу. Так что формальноюридически (в рамках действовавших тогда советских законов) следствие по делу краеведов документов не сфальсифицировало, как это широко распространилось среди чекистов с нарастанием Большого террора (Щелкунов, 2018. С. 35-42). Незаконными были не протоколы допросов, а методы их получения, а также финал внесудебной кары по этому процессу.

Кроме Введенского особенно убийственные показания против своих коллег дали куряне - учитель, богослов, лидер губернского общества краеведов Г.И. Булгаков и нумизмат музея Т.А. Горохов. В итоге краеведческие общества были обвинены в том, что они «содержат в себе много социальных элементов, чуждых советскому строю, а иногда прямо ему враждебных». В обвинении значилось, что в городах ЦЧО, особенно в Воронеже, «под прикрытием научной работы» в краеведческих организациях «проводилась антисоветская работа...» с целью «уничтожения сов. строя и замены его буржуазно-демократической республикой».

Следствие по делу 92 краеведов ЦЧО закончилось 5 мая 1931 года. В постановлении ОГПУ констатировалось, что все подследственные «вполне изобличены в предъявленном им преступлении, предусмотренном ст. 58-10, 11 Уголовного кодекса». Коллегия ОГПУ в Москве без суда, заочно, не вызывая обвиняемых, 5 июня 1931 года вынесла приговор. Пятерых приговорили к расстрелу, большинство - к заключению в концлагерь сроком от 3 до 10 лет (по 5 лет получили главные фигуранты дела - воронежские краеведы Введенский, А.М. Путинцев, Т.М. Олейников, В.В. Литвинов, руководитель курских краеведов Г.И. Булгаков), нескольких - к высылке в Северный край, Западную Сибирь, Казахстан. Рядовые, по версии следствия, «заговорщики» в целом получили не менее суровые наказания, чем их столичные «вербовщики» и «руководители» из числа сотрудников АН СССР и Центрального бюро краеведения. Единственный обвиняемый - воронежец В.А. Преображенский - оказался освобожден из-под стражи, следствие в отношении него прекратили.

Сопоставимые с ЦЧО по количеству жертвы понесли в период Большого террора археологические организации Белоруссии, Украины и некоторых других субъектов СССР (Формозов, 2006). 
Так был положен конец мало-мальски организованному и результативному краеведческому движению в нашей стране. С этих пор и вплоть до послевоенного периода на местах некому стало вести разведки и раскопки памятников археологии; квалифицированно разбирать, хранить и экспонировать коллекции древностей. С рубежа 19401950-х гг. в отдельных областях Российской Федерации снова появились одиночные энтузиасты полевой и музейной археологии. Они оказывали большую помощь экспедициям из Москвы, Ленинграда и Киева и даже сами кое-что разведывали да копали, но заменить целые коллективы знатоков древностей уже не могли.

Только в июле 1978 года Воронежский областной суд отменил вынесенный по «делу краеведов» приговор «за отсутствием события преступления».

\section{ЛИТЕРАТУРА}

Полномочное представительство ОГПУ по ЦЧО. Курский оперсектор. Дело «Краеведы» // Государственный архив общественно-политической истории Воронежской области. Ф. 93534. Д. 16967. Оп. 2. Ч. 4. 1931 г. Л. 1-87.

Формозов А.А., 2006. Русские археологи в период тоталитаризма. Историографические очерки. Изд. 2-е., доп. М.: Знак. 344 с.

Щавелёв С.П., 2007. «Дело краеведов ЦЧО» 1930-1931 годов. (Курский «филиал»). Курск.: Изд. Курс. гос. мед. Университета. 271 с.

Щелкунов А.А., 2018. Тотальный следственный подлог как инструмент Большого террора // Российская история. № 4. С. 43-57. 


\section{СПИСОК СОКРАЩЕНИЙ}

БАМ

BAO

ВГУ

ВИ

ВСОРГО

ГАЗК

ГАИМК

ГАКК

ГAOO

ГАOO

ГАРФ

ГАТO

ГИМ

ГИНО

Главмузей

Главнаука

Губмузей

ГубОНО

ГУЛАГ

ГУС

ДВР

ЗККМ

ЗОРГО

ИАИ РАНИОН

ИАК

ИА РАН

ИИМК РАН

ИИС

ИСЭГИ
- Байкало-Амурская магистраль

- Вотская автономная область

- Воронежский государственный университет

- Вопросы истории

- Восточно-Сибирский отдел русского географического общества

- Государственный архив Забайкальского края, г. Чита

- Государственная академия истории материальной культуры

- Государственный архив Красноярского края

- Государственный архив Одесской области

- Государственный архив Оренбургской области

- Государственный архив Российской Федерации

- Государственный архив Тверской области

- Государственный исторический музей

- Государственный институт народного образования, ДВР

- Главный комитет по делам музеев и охране памятников искусства, старины и природы при Наркомпросе РСФСР

- Главное управление научными, научно-художественными и музейными учреждениями при Наркомпросе РСФСР

- Губернское управление Отдела по делам музеев

- Губернский отдел народного образования

- Государственное управление лагерями ОГПУ/НКВД

- Государственный ученый совет при Наркомпросе РСФСР

- Дальневосточная республика

- Забайкальский краевой краеведческий музей, г. Чита

- Забайкальский отдел Русского географического общества

- Институт археологии и искусствознания РАНИОН

- Императорская археологическая комиссия

- Институт археологии РАН

- Институт истории материальной культуры РАН

- Институт исследования Сибири

- Институт социально-экономических и гуманитарных исследований ЮНЦ РАН, г. Ростов-на-Дону

- Исправительно-трудовой лагерь 


\begin{tabular}{|c|c|}
\hline КАССР & $\begin{array}{l}\text { - Киргизская автономная советская социалистическая респуб- } \\
\text { лика }\end{array}$ \\
\hline КГО & - Кавказское горное общество \\
\hline KMB & $\begin{array}{l}\text { - Кавказские Минеральные Воды - административно-тер- } \\
\text { риториальное и географическое образование в центральных } \\
\text { районах Северного Кавказа и особо охраняемый эколого- } \\
\text { курортный регион Российской Федерации }\end{array}$ \\
\hline КОРГО & - Красноярский отдел Русского географического общества \\
\hline КрымОХРИС & $\begin{array}{l}\text { - Крымский областной комитет по делам музеев и охране па- } \\
\text { мятников старины, искусства и природы }\end{array}$ \\
\hline КрайОНО & - Краевой отдел народного образования \\
\hline КСИА & - Краткие сообщения Института археологии РАН \\
\hline ЛИЭТО & - Литературно-историческое и этнологическое общество \\
\hline $\begin{array}{l}\text { ЛОИА АН } \\
\text { СССР }\end{array}$ & $\begin{array}{l}\text { - Ленинградское отделение Института археологии Академии } \\
\text { наук СССР }\end{array}$ \\
\hline МАИ & - Московский археологический институт \\
\hline MAO & - Московское археологическое общество \\
\hline МАЭ РАН & - Музей антропологии и этнографии им. Петра Великого РАН \\
\hline МГУ & $\begin{array}{l}\text { - Московский государственный университет им. М.В. Ломоно- } \\
\text { сова }\end{array}$ \\
\hline Музейный отдел & $\begin{array}{l}\text { - Отдел по делам музеев и охране памятников искусства и ста- } \\
\text { рины Наркомпроса РСФСР }\end{array}$ \\
\hline HA IA НАНУ & $\begin{array}{l}\text { - Научный архив Института археологии Национальной акаде- } \\
\text { мии наук Украины }\end{array}$ \\
\hline НА КККМ & $\begin{array}{l}\text { - Научный архив Красноярского краевого краеведческого му- } \\
\text { зея }\end{array}$ \\
\hline $\begin{array}{l}\text { Наркомпрос } \\
\text { РСФСР }\end{array}$ & - Народный комиссариат просвещения РСФСР \\
\hline НКВД & - Народный комиссариат внутренних дел \\
\hline НОИВК & - Научное общество изучения Вотского края \\
\hline НЭП & - Новая экономическая политика \\
\hline ОАИЭ & $\begin{array}{l}\text { - Общество археологии, истории и этнографии при Казанском } \\
\text { университете }\end{array}$ \\
\hline ОГПУ & - Объединенное государственное политическое управление \\
\hline ОИМК & - Общество изучения Маньчжурского края, г. Харбин \\
\hline ОПИ ГИМ & - Отдел письменных источников ГИМ \\
\hline ОУАК & - Оренбургская ученая архивная комиссия \\
\hline РАИМК & - Российская Академия истории материальной культуры \\
\hline РАНИОН & $\begin{array}{l}\text { - Российская ассоциация научно-исследовательских институ- } \\
\text { тов общественных наук }\end{array}$ \\
\hline
\end{tabular}


PAO

РГАК

РИМ

РИО КГПУ
- Русское археологическое общество

- Российская государственная археологическая комиссия

- Российский исторический музей (потом ГИМ)

- Редакционный отдел Красноярского государственного педагогического университета им. В.П. Астафьева

РО НА ИИМК РАН - Рукописный отдел Научного архива ИИМК РАН

$\mathrm{CA}$

- Советская археология

СОАИЭиЕ

CAO

СКАНИИ

СКФУ

СКЭ

СОИКМ

CO PAH

СПб ГУ

СПбФ АРАН

ТГУ

ТСА РАНИОН

ТУАК

ЦБК

$\Phi O H$

ЦГАВОВУ

ЦГА СПб

ЦГАУР

Центрархив

ЦЧО

ЮНЦ
- Самарское общество археологии, истории, этнографии и естествознания при Самарском университете

- Самарское археологическое общество

- Северо-Кавказский научно-исследовательский институт краеведения

- Северо-Кавказский федеральный университет, г. Ставрополь

- Северокавказская экспедиция РАИМК-ГАИМК, г. Ленинград

- Самарский областной историко-краеведческий музей им. П.В. Алабина

- Сибирское отделение института археологии РАН

- Санкт-Петербургский государственный университет

- Санкт-Петербургский филиал Архива РАН

- Тамбовский государственный университет

- Труды секции археологии РАНИОН

- Тамбовская ученая архивная комиссия

- Центральное бюро краеведения

- Факультет общественных наук

- Центральный государственный архив высших органов власти Украины

- Центральный государственный архив Санкт-Петербурга

- Центральный государственный архив Удмуртской республики

- Управление Центральным архивом при ВЦИК РСФСР

- Центрально-Чернозёмная область

- Южный научный центр РАН, г. Ростов-на-Дону 


\section{СВЕДЕНИЯ ОБ АВТОРАХ}

Алкин Сергей Владимирович - к.и.н., с.н.с. Отдела археологии палеометалла, Институт археологии и этнографии СО РАН, г. Новосибирск.

Белова Наталья Андреевна - н.с. Рукописного отдела Научного архива, Институт истории материальной культуры РАН, г. Санкт-Петербург.

Белозёрова Ирина Валентиновна - с.н.с. Отдела письменных источников, Государственный исторический музей, г. Москва.

Бессуднов Александр Николаевич - к.и.н., доцент кафедры отечественной и всеобщей истории, Липецкий государственный педагогический университет им. П.П. Семёнова-Тян-Шанского, г. Липецк.

Бойко Андрей Леонидович - к.и.н., доцент кафедры археологии и истории древнего мира, кандидат исторических наук, Южный федеральный университет, г. Ростов-на-Дону

Бояркин Михаил Викторович - аспирант кафедры археологии и истории древнего мира, Воронежский государственный университет, г. Воронеж.

Вдовин Александр Сергеевич - к.и.н., с.н.с., Красноярский краевой краеведческий музей, г. Красноярск.

Евгеньев Андрей Александрович - к.и.н, доцент кафедры истории России, Оренбургский государственный педагогический университет, г. Оренбург.

Жукова Елена Николаевна - к.и.н., доцент кафедры отечественной истории, Тверской государственный университет, г. Тверь.

Захарова Елена Юрьевна - д.и.н., доцент кафедры археологии и истории древнего мира, Воронежский государственный университет, г. Воронеж.

Канторович Анатолий Робертович - д.и.н., зав. кафедрой археологии исторического факультета, Московский государственный университет им. М.В. Ломоносова, г. Москва.

Китова Людмила Юрьевна - д.и.н., профессор кафедры археологии, Кемеровский государственный университет, г. Кемерово.

Коробов Дмитрий Сергеевич - д.и.н., проф., зав. Отделом теории и методики, Институт археологии РАН, г. Москва.

Кузьминых Сергей Владимирович - к.и.н., с.н.с. Лаборатории естественнонаучных методов, Институт археологии РАН, г. Москва.

Левченко Валерий Валерьевич - к.и.н., доцент, Одесский национальный морской университет, г. Одесса (Украина).

Макаров Николай Поликарпович - к.и.н., зав. Отделом археологии и этнографии, Красноярский краевой краеведческий музей, г. Красноярск. 
Медведева Мария Владимировна - к.и.н., с.н.с., зав. Научным архивом, Институт истории материальной культуры РАН, г. Санкт-Петербург.

Мельникова Ольга Михайловна - д.и.н., зав. кафедрой истории Удмуртии, археологии и этнологии, Удмуртский государственный университет, г. Ижевск.

Непомнящий Андрей Анатольевич - д.и.н., проф., зав. кафедрой исторического регионоведения и краеведения, Крымский федеральный университет им. В.И. Вернадского, г. Симферополь.

Палиенко Сергей Владимирович - к.и.н., независимый исследователь, г. Киев (Украина).

Панкратова Евгения Григорьевна - к.и.н., с.н.с., Санкт-Петербургский филиал Архива РАН, г. Санкт-Петербург.

Платонова Надежда Игоревна - д.и.н., в.н.с. Отдела славяно-финской археологии, Институт истории материальной культуры РАН, г. Санкт-Петербург.

Руденко Константин Александрович - д.и.н., профессор кафедры истории, музееведения и искусствоведения, Казанский государственный университет культуры и искусств, г. Казань.

Савенко Сергей Николаевич - к.и.н., заслуженный работник культуры РФ, директор ГБУК Ставропольского края «Пятигорский краеведческий музей», г. Пятигорск.

Сорокина Ирина Анатольевна - к.и.н., с.н.с. Отдела теории и методики, Институт археологии РАН, г. Москва.

Сташенков Дмитрий Алексеевич - к.и.н., ученый секретарь, Самарский областной историко-краеведческий музей им. П.В. Алабина, г. Самара.

Тихонов Игорь Львович - д.и.н., профессор кафедры археологии, зав. Музеем истории СПбГУ, Санкт-Петербургский государственный университет, г. СанктПетербург.

Ткачёв Алексей Николаевич - магистр истории, соискатель кафедры всеобщей истории и международных отношений, Кубанский государственный университет, г. Краснодар.

Толочко Ирина Викторовна - к.и.н., с.н.с. Лаборатории археологических исследований, Южный научный центр РАН, г. Ростов-на-Дону.

Тункина Ирина Владимировна - д.и.н., директор Санкт-Петербургского филиала Архива РАН, г. Санкт-Петербург.

Усачук Анатолий Николаевич - с.н.с., к.и.н., Донецкий краеведческий музей, г. Донецк.

Щавелёв Сергей Павлович - д.и.н., д.филос.н., профессор, зав. кафедрой философии, Курский государственный медицинский университет, г. Курск. 



\section{У ИСТОКОВ СОВЕТСКОЙ АРХЕОЛОГИИ: ОРГАНИЗАЦИИ И УЧРЕЖДЕНИЯ АРХЕОЛОГИЧЕСКОГО ПРОФИЛЯ В НОВЫХ РЕАЛИЯХ}

\section{МАТЕРИАЛЫ МЕЖДУНАРОДНОЙ} НАУЧНОЙ КОНФЕРЕНЦИИ

Научное издание

Техническое редактирование и верстка: С.В. Кожушков

$$
\begin{gathered}
\text { Подписано в печать 14.02.2019. Формат } 60 \text { × } 90 \text { 1/8 } \\
\text { Усл. печ. л. 8,0. Уч-изд. л. 5,5. Тираж } 150 \text { экз. }
\end{gathered}
$$

Институт археологии РАН

117036 Москва, ул. Дм. Ульянова, 19

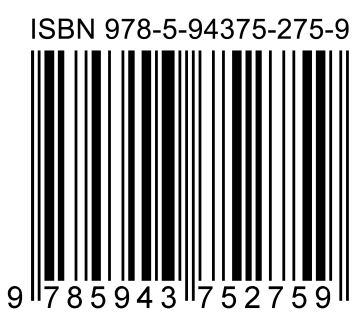

